\title{
U. S. Department of Energy Portsmouth Annual Environmental Report For 1998
}

Date Issued — December 1999

\author{
Prepared by \\ EQ Midwest, Inc. \\ Cincinnati, $\mathrm{OH}$ \\ under subcontract 23900-SC-SM002F
}

Prepared for the

U. S. Department of Energy

Office of Environmental Restoration and Waste Management

\section{BECHTEL JACOBS COMPANY LLC \\ managing the}

Environmental Management Activities at the

Portsmouth Gaseous Diffusion Plant

Bechtel Jacobs Company LLC

P.O. Box 900

Piketon, Ohio 45661

under contract DE-AC05-98OR22700

for the

U.S. DEPARTMENT OF ENERGY 
This document has received the appropriate reviews for release to the public. 


\section{DISCLAIMER}

This report was prepared as an account of work sponsored by an agency of the United States Government. Neither the United States Government nor any agency thereof, nor any of their employees, make any warranty, express or implied, or assumes any legal liability or responsibility for the accuracy, completeness, or usefulness of any information, apparatus, product, or process disclosed, or represents that its use would not infringe privately owned rights. Reference herein to any specific commercial product, process, or service by trade name, trademark, manufacturer, or otherwise does not necessarily constitute or imply its endorsement, recommendation, or favoring by the United States Government or any agency thereof. The views and opinions of authors expressed herein do not necessarily state or reflect those of the United States Government or any agency thereof. 


\section{DISCLAIMER}

Portions of this document may be illegible in electronic image products. Images are produced from the best available original document. 


\section{Contents}

Tables

Figures

Acronyms

Executive Summary.

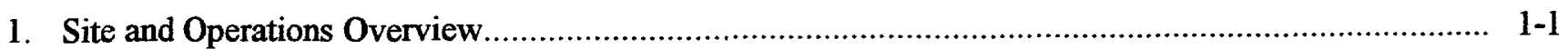

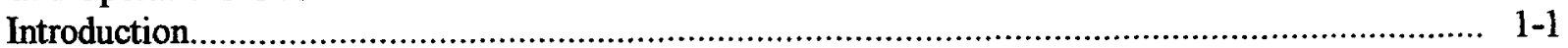

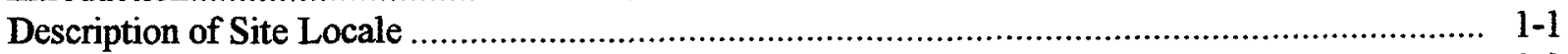

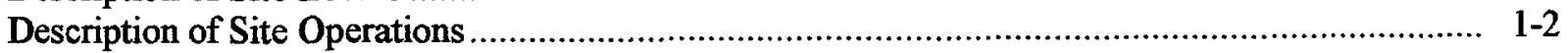

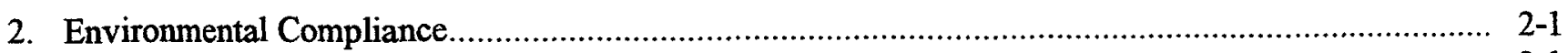

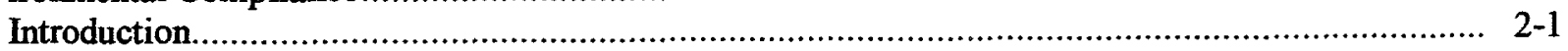

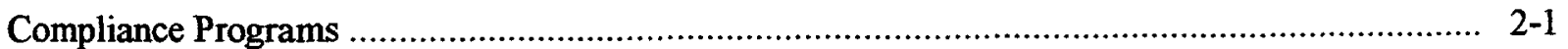

Ohio Consent Decree and U.S. EPA Administrative Consent Order................................. 2-1

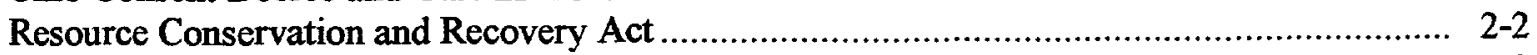

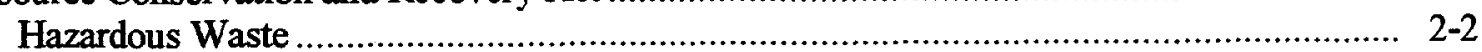

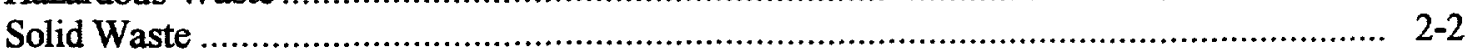

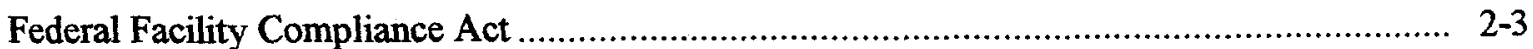

Comprehensive Environmental Response, Compensation, and Liability Act ......................... 2-3

Toxic Substances Control Act ............................................................................. 2-4

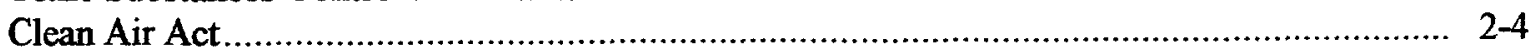

Clean Air Act, Title VI, Stratospheric Ozone Protection.......................................... 2-5

National Emission Standards for Hazardous Air Pollutants........................................ 2-5

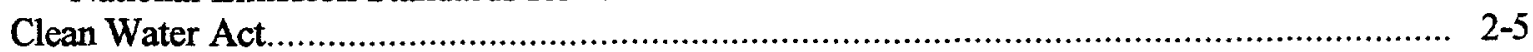

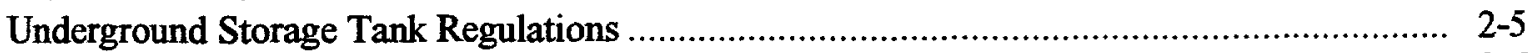

Emergency Planning and Community Right-to-Know Act ........................................ 2-6

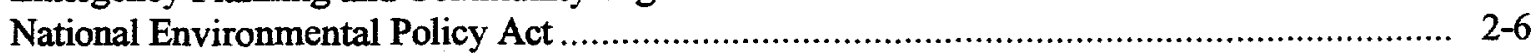

Federal Insecticide, Fungicide, and Rodenticide Act............................................... 2-7

Other Environmental Acts and Federal Regulations ..................................................... 2-7

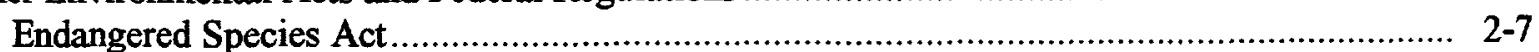

National Historic Preservation Act ..................................................................... 2-7

Archaeological and Historic Preservation Act and Archaeological Resources

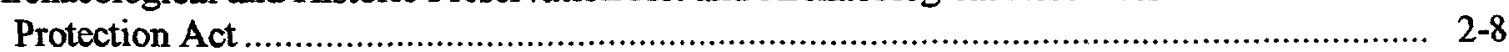

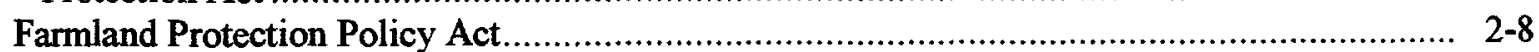

Title 10 Code of Federal Regulations Part 1022, "Compliance with Floodplain/Wetlands

Environmental Review Requirements" .............................................................. 2-8

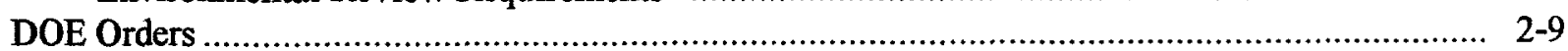

DOE Order 5400.1, General Environmental Protection Program....................................... 2-9

DOE Order 5400.5, Radiation Protection of the Public and the Environment ......................... 2-10 
Environmental Program Inspections and Visits ........................................................................... 2-10

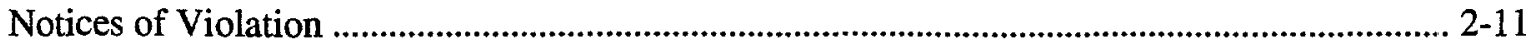

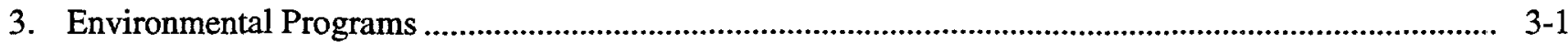

Environmental Restoration Program ............................................................................................. 3-1

Cleanup Alternatives Study/Corrective Measures Study …....................................................... 3-2

Corrective Measures Implementation ............................................................................................... 3-2

X-749B Peter Kiewit Landfill .............................................................................................. 3-2

X-700 Containment Tank/X-720 Neutralization Pit Removal ............................................ 3-2

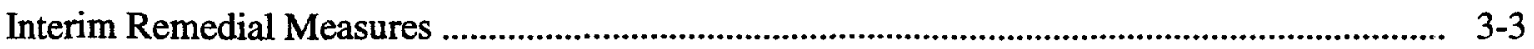

Additional Cleanup Alternatives Study/Corrective Measures Study Activities ............................ 3-3

Sitewide Surface Drainage Ditches .............................................................................. 3-3

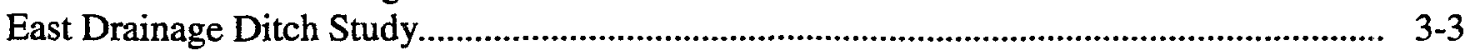

Big Run Creek and Southwest Drainage Ditch Study .................................................. $3-4$

North Drainage Ditch Study ............................................................................................ 3-4

Northeast Drainage Ditch Study................................................................................ $3-4$

Technology Applications ....................................................................................................... 3-4

X-701B In Situ Chemical Oxidation ................................................................................ $3-4$

X-231A Soil Fracturing Demonstration ............................................................................. 3-5

X-625 Passive Groundwater Treatment through Reactive Media....................................... 3-5

X-749/X120 Vacuum Enhanced Recovery Wells ............................................................... 3-6

5-Unit Area (Quadrant I Groundwater Investigative Area) Oxidant Injection ....................... 3-6

X-701B Underground Steam Stripping and Hydrous Pyrolysis/Oxidation Project............... 3-6

Waste Management Program .................................................................................................. 3-7

Waste Minimization and Pollution Prevention Program ............................................................. 3-8

Environmental Training Program ......................................................................................... 3-9

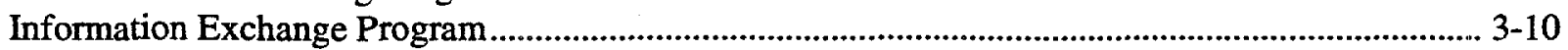

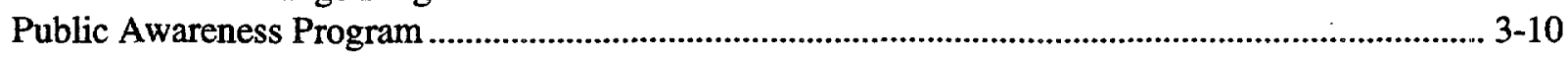

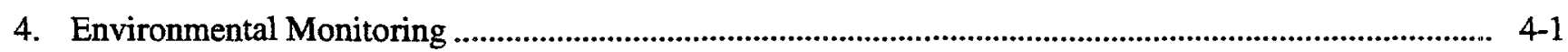

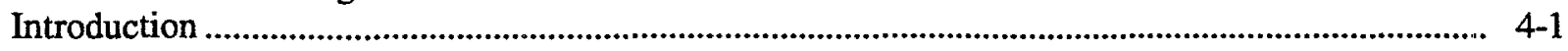

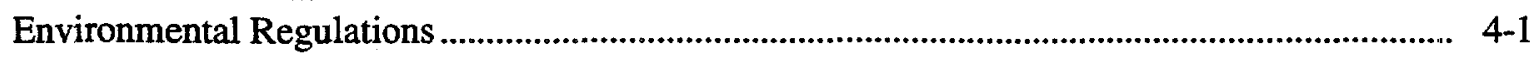

Critical Pathway Analysis ........................................................................................................ 4-2

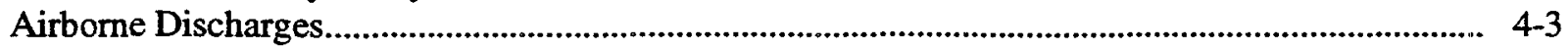

Radiological Airborne Discharges ................................................................................... 4-3

Radiological Air Sample Collection and Analytical Procedure ........................................... 4-3

Radiological Air Estimation Results .............................................................................. 4-3

Nonradiological Airborne Discharges ............................................................................... 4-4

Nonradiological Air Sample Collection and Analytical Procedure ........................................ 4-4

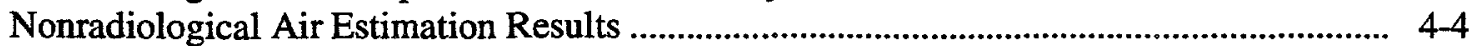

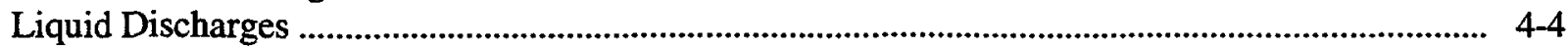

Radiological Liquid Discharges ............................................................................................. 4-5

Radiological Liquid Sample Collection and Analytical Procedure...................................... 4-5

Radiological Liquid Monitoring Results............................................................................ 4-5

Radiological Monitoring Results for Surface Water from DOE Cylinder Storage Yards..... 4-5

Nonradiological Liquid Discharges ......................................................................................... 4-5

Nonradiological Liquid Sample Collection and Analytical Procedure ................................. 4-7

Nonradiological Liquid Monitoring Results ...................................................................... 4-7

Radiological and Nonradiological Groundwater Monitoring Results ....................................... 4-7

Biological Monitoring ......................................................................................................... 4-7 
5. Dose

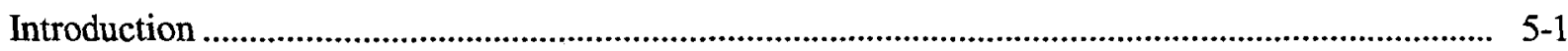

Radiological Dose Calculation ....................................................................................................... 5

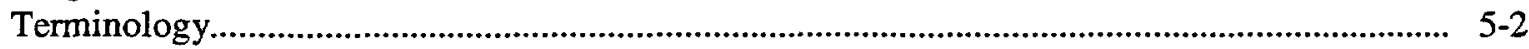

Dose Calculation for Airborne Radionuclides........................................................................... 5-3

Airborne Radionuclide Dose Calculation Results ....................................................................... 5-3

Dose Calculation for Waterborne Radionuclides ..................................................................... 5-4

Radiological Dose Results for DOE/PORTS Workers and Visitors............................................ 5-4

Radiological Dose Results from DOE/PORTS Facilities .......................................................... 5-4

Calculation of Direct Exposure to Chemicals ................................................................................... 5-5

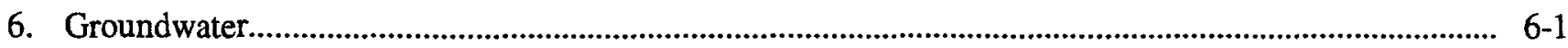

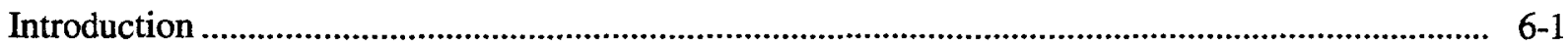

Uses of Groundwater in the Vicinity ................................................................................................ 6-1

Applicable Monitoring Standards................................................................................................. $6-2$

Groundwater Monitoring at DOE/PORTS ............................................................................... $6-2$

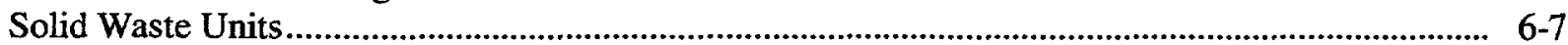

X-735 Industrial Solid Waste Landfill............................................................................. 6-7

X-749A Classified Materials Disposal Facility .......................................................................... 6-7

X-749 Contaminated Materials Storage Yard (Southern Portion) ................................................. 6-9

RCRA Hazardous Waste Units...................................................................................................... 6

X-231B Southwest Oil Biodegradation Plot...................................................................... 6-9

$\mathrm{X}-616$ Chromium Sludge Surface Impoundments .................................................................... 6-12

X-701B Holding Pond.................................................................................................. 6-12

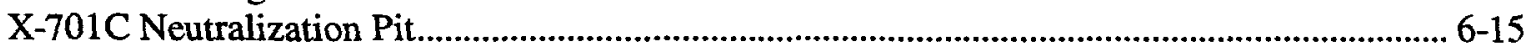

X-735 RCRA Landfill (Northern Portion) ............................................................................ 6-16

X-749 Contaminated Materials Storage Yard (Northern Portion) ................................................. 6-18

RCRA Corrective Action Units ................................................................................................... 6-18

X-611A Lime Sludge Lagoons ................................................................................... 6-20

X-749B Peter Kiewit Landfill ............................................................................................... 6-20

Surveillance Monitoring Program .............................................................................................. 6-20

Perimetèr Exit Pathway Monitoring ……................................................................................ 6-23

Baseline Monitoring ...................................................................................................................... 6-23

Off-Site Sampling .................................................................................................................... 6-23

Groundwater Treatment Units ........................................................................................................ 6-23

X-622 Groundwater Treatment Facility.................................................................................... 6-23

X-622T Groundwater Treatment Facility .................................................................................. 6-26

X-623 Groundwater Treatment Facility ...................................................................................... 6-26

X-624 Groundwater Treatment Facility................................................................................. 6-26

X-625 Groundwater Treatment Facility............................................................................. 6-26

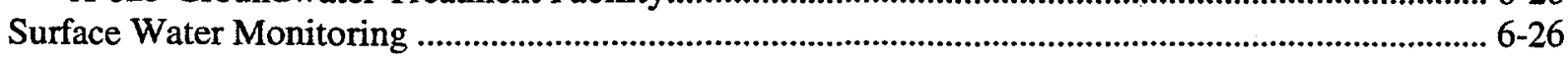

7. Quality Assurance

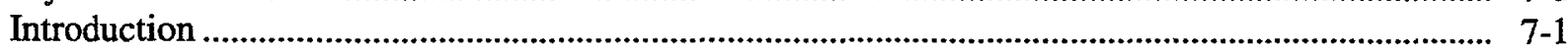

Field Sampling and Monitoring …………........................................................................... $7-1$

Analytical Quality Assurance ............................................................................................................ 7-2

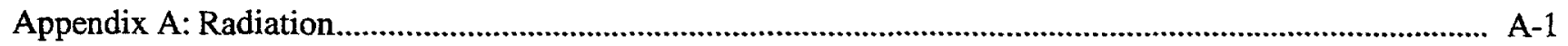

Appendix B: Environmental Permits ........................................................................................................ B-1 
Appendix C: Radionuclide and Chemical Nomenclature

C-1

References

R-1

Glossary

G-1 


\section{Figures}

Figure

1.1 Location of PORTS within the State of Ohio .......................................................... $1-1$

1.2 Location of PORTS in relation to the geographic region. ..............................................

4.1 NPDES water sampling locations and major wastewater sources and systems at DOE/PORTS ...... 4-6

4.2 Flow diagram for outfalls 012 and 013 (X-2230M holding pond and X-2230N holding pond)....... 4-7

$4.3 \quad$ Flow diagram for outfall 015 (X-624 carbon filtration facility) .......................................... $4-7$

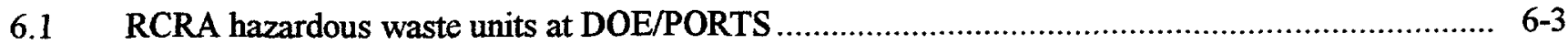

6.2 Solid waste landfill disposal units at DOE/PORTS ...........................................................

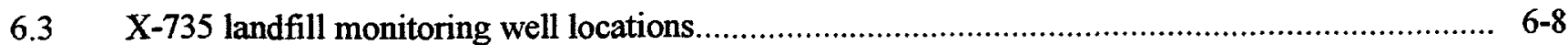

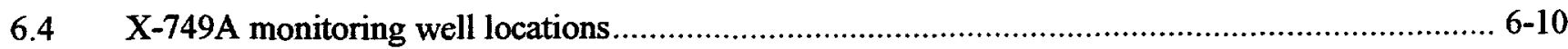

6.5 X-231B southwest oil biodegradation plot Gallia groundwater trichloroethene plume fourth quarter, 1998

6.6 X-616 chromium sludge surface impoundments dissolved chromium results second semester, 1998

6.7 X-701B holding pond Gallia groundwater trichloroethene plume fourth quarter, 1998 6-14

6.8 X-701C neutralization pit Gallia groundwater trichloroethene plume second semester, 1998 6-17

6.9 X-749 contaminated material storage yard Gallia groundwater trichloroethene plume second semester, 1998

6.10 X-611A lime sludge lagoons monitoring well locations

6.11 X-749B Peter Kiewit landfill monitoring wells and Gallia trichloroethene plume, fourth quarter 1998 .

6.12 Perimeter exit pathway and baseline monitoring locations at DOE/PORTS

6.13 Portsmouth off-site sampling locations

6.14 Surface water monitoring locations. 


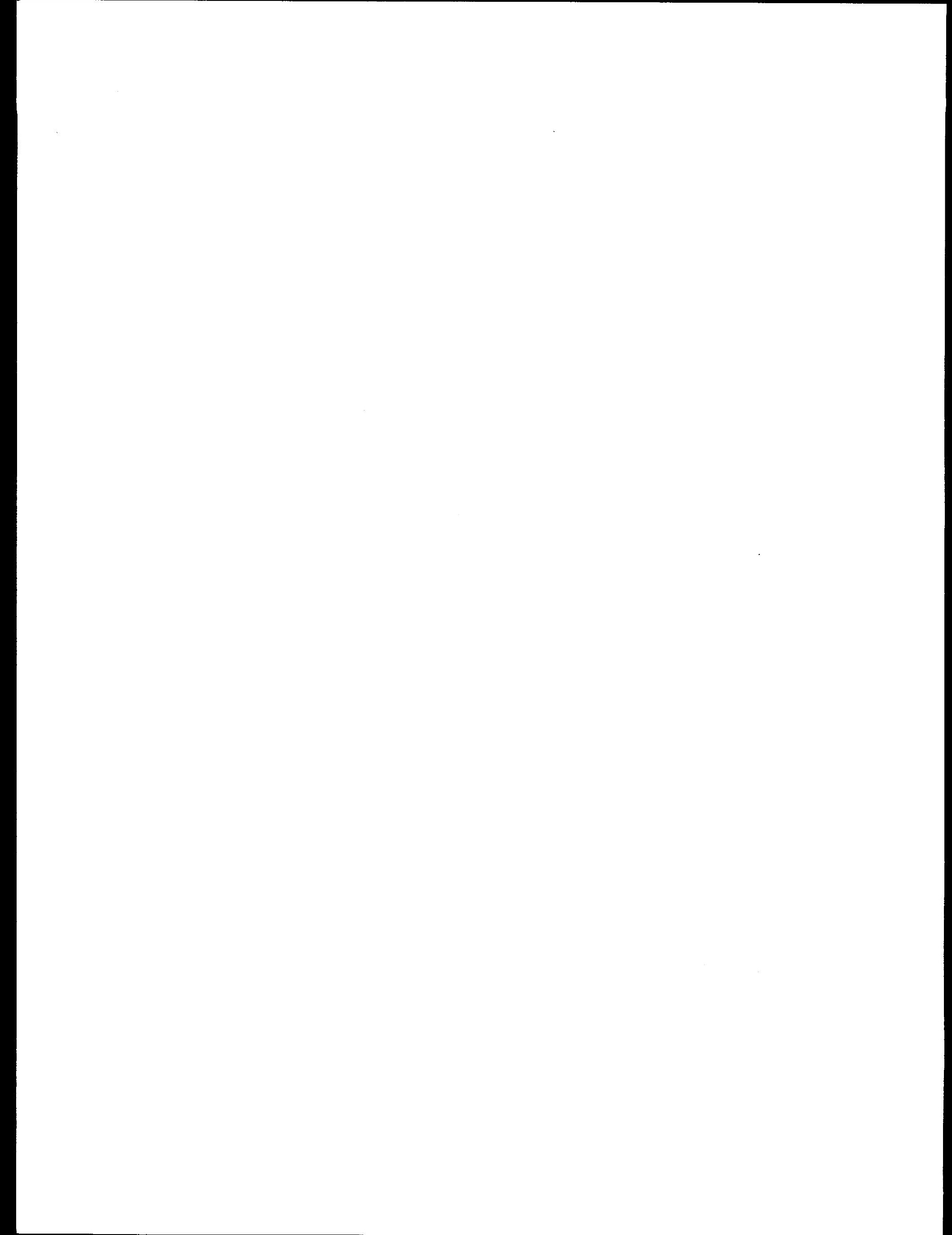




\section{Tables}

Table

Page

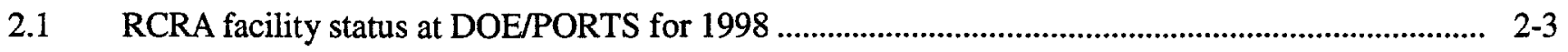

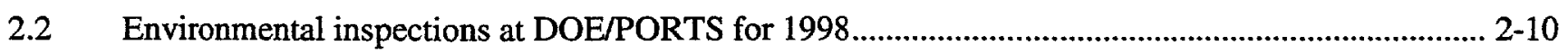

3.1 Waste management treatment, disposal, and recycling accomplishments for 1998 ....................... 3-8

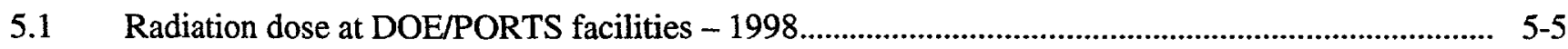

6.1 Analyte analysis required for groundwater monitoring at RCRA hazardous waste units, solid waste units, corrective action units, surface water locations, and off-site locations at DOE/PORTS 



\section{Acronyms}

$\mathrm{Bq}$

Becquerel

$\mathrm{Ci}$

curie

DOE

U.S. Department of Energy

EPA

Environmental Protection Agency

$\mathrm{kg}$

kilogram

$\mu \mathrm{g} / \mathrm{L}$

microgram per liter (equivalent to part per billion)

NPDES

National Pollutant Discharge Elimination System

$\mathrm{pCi} / \mathrm{L}$

picocurie per liter

PORTS

Portsmouth Gaseous Diffusion Plant

RCRA

Resource Conservation and Recovery Act

TLD

thermoluminescent dosimeter

USEC

United States Enrichment Corporation 



\section{Executive Summary}

\section{SITE AND OPERATIONS OVERVIEW}

The Portsmouth Gaseous Diffusion Plant (PORTS) is one of two U.S. Department of Energy (DOE)owned contractor-managed uranium enrichment facilities operating in the United States (see Fig. 1).

Responsibility for implementing environmental compliance at PORTS is split between DOE, as site owner, and the United States Enrichment Corporation (USEC), a corporation formed by the Energy Policy Act of 1992 to operate the nation's uranium enrichment business. The uranium enrichment production and operations facilities at the site are leased to USEC.

Martin Marietta Energy Systems and Lockheed Martin Energy Systems were the management contractors for DOE from November 1986 through March 1998. On April 1, 1998, Bechtel Jacobs Company LLC assumed responsibility as the management contractor for DOE. Bechtel Jacobs Company is responsible for environmental restoration, waste management, removal of highly enriched uranium, and operation of nonleased facilities (facilities that are not leased to USEC) at PORTS. This report does not cover USEC operations at PORTS.

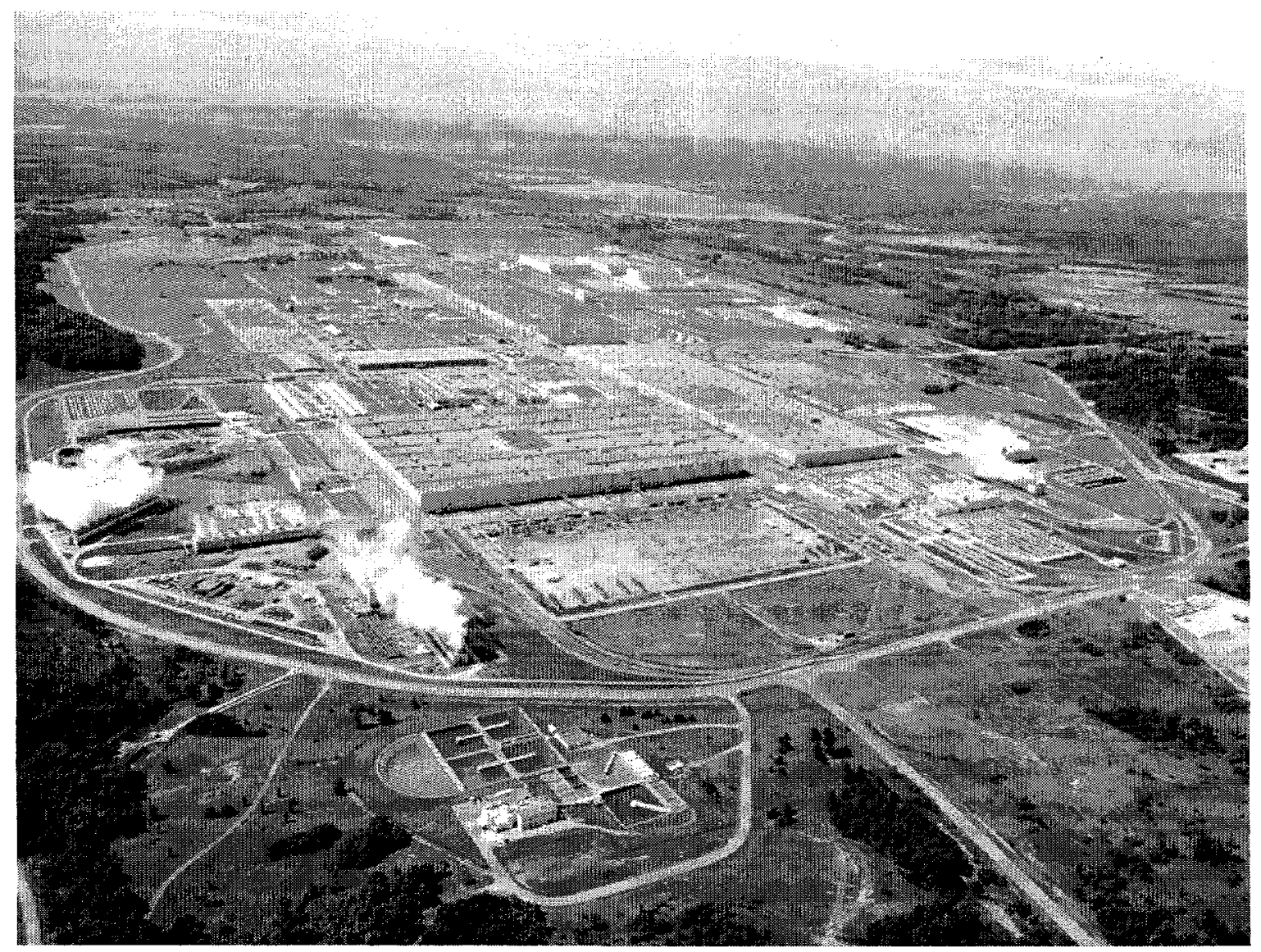

Fig. 1. PORTS is one of two U.S. government-owned contractor-managed uranium enrichment facilities in operation. The other facility is in Paducah, Kentucky. 
PORTS is located on 5.8 square miles in Pike County, Ohio. The county has approximately 24,250 residents.

\section{ENVIRONMENTAL COMPLIANCE}

Several federal, state, and local agencies are responsible for enforcing environmental regulations at PORTS. DOE/PORTS conducts a self-assessment program that addresses environmental concerns and involves regulatory agencies to verify appropriate actions are being taken to maintain compliance. DOE/PORTS has been issued a National Pollutant Discharge Elimination System (NPDES) permit for discharge of water to surface streams, several air emission permits, and a Resource Conservation and Recovery Act (RCRA) permit for storage of hazardous wastes.

Environmental compliance activities in 1998 included (1) closure of the X-326 trap material storage area under RCRA hazardous waste requirements, (2) closure of the X-735 Industrial Solid Waste Landfill, (3) closure of the X-749B Peter Kiewit Landfill, (4) continued management of polychlorinated biphenyls in accordance with the Toxic Substances Control Act and the PORTS federal facilities compliance agreement, (5) preparation of the annual National Emissions Standards for Hazardous Air Pollutants report for radiological emissions, (6) ongoing monitoring of NPDES outfalls, (7) closure of one underground storage tank, (8) submittal of information for the hazardous chemical inventory required by the Emergency Planning and Community Right-to-Know Act, and (9) submittal of the Toxic Chemical Release inventory report.

None of the NPDES permit limits were exceeded during 1998. No violations of air permits or National Emission Standards for Hazardous Air Pollutants limits occurred in 1998 at DOE/PORTS. No unplanned releases of hazardous substances that required reporting under environmental regulations occurred in 1998.

In 1998, one Notice of Violation was issued to DOE by Ohio EPA. The Notice of Violation stated that weekly inspection records for a hazardous waste accumulation area at the X-622 facility were not adequately maintained, and the closure of this accumulation area was not in accordance with Ohio regulations. On August 19, 1998, the Ohio EPA determined that the violations had been abated.

\section{ENVIRONMENTAL PROGRAMS}

Environmental restoration, waste management, and public information programs are conducted to protect and inform the local population, improve the quality of the environment, and comply with federal and state regulations.

\section{Environmental Restoration Program}

Environmental restoration is the process of cleaning up inactive waste sites and facilities to demonstrate that risks to human health and the environment are either eliminated or reduced to safe levels. DOE established the Environmental Restoration Program to find, analyze, and correct site contamination problems as quickly and inexpensively as possible. This task may be accomplished by removing, stabilizing, or treating hazardous substances. The DOE/PORTS Environmental Restoration Program was developed in 1989. Since then, annual program expenditures peaked at $\$ 75.9$ million and are now declining as environmental restoration activities progress toward completion. Program expenditures in 1998 were $\$ 23$ million.

The Ohio Consent Decree and the U.S. Environmental Protection Agency (U.S. EPA) Administrative Consent Order require investigation and cleanup of PORTS in accordance with the RCRA Corrective Action Program. The site is divided into four quadrants to facilitate the investigation and cleanup. In 1998, DOE submitted a Cleanup Alternatives Study/Corrective Measures Study for two of the four quadrants. Ohio EPA 
and U.S. EPA approved the Cleanup Alternatives Study/Corrective Measures Study for Quadrant III on July 13, 1998 and Quadrant IV on October 18, 1998. Preparation of the Cleanup Alternatives Studies/Corrective Measures Studies for Quadrants I and II continued during 1998.

\section{Waste Management Program}

The DOE/PORTS Waste Management Program directs the safe storage, treatment, and disposal of waste generated from plant operations and from environmental restoration projects.

Waste management requirements are varied and often complex because of the variety of wastes generated by DOE/PORTS activities, including radioactive, hazardous (chemical), polychlorinated biphenyls, asbestos, industrial, and mixed (radioactive and hazardous) wastes. DOE Orders, Ohio EPA regulations, and U.S. EPA regulations must be satisfied to demonstrate compliance of waste management activities.

Supplemental policies also have been implemented for waste management including:

- minimizing waste generation;

- characterizing and certifying wastes before they are stored, processed, treated, or disposed;

- pursuing volume reduction and use of on-site storage when safe and cost-effective until a final treatment and/or disposal option is identified; and

- recycling.

\section{Public Awareness Program}

DOE provides a public Environmental Information Center to allow access to all documents used to make decisions on remedial actions being taken at PORTS. The information center is located on the plant-site just outside the E-Vehicle portal and is open 9 a.m. to 12 p.m. Monday and Tuesday, 12 p.m. to 4 p.m. Wednesday and Thursday, or by appointment (740/947-5093). Additional information is provided by the DOE Site Office (740-897-5521) and the Bechtel Jacobs Company Public Affairs Manager (740-897-2336).

Semiannual public update meetings and public workshops on specific topics are held to keep the public informed and to receive their comments and questions. In addition to the two public meetings held in 1998, meetings were held on the Depleted Uranium Hexafluoride Management Program and "Accelerating Cleanup: Paths to Closure." Fact sheets about major projects are produced periodically for the public, and semiannual environmental bulletins are printed and distributed to more than 4,000 recipients, including those on the community relations mailing list, neighbors residing within 2 miles of PORTS, and all plant employees and retirees. Newsletters and fact sheets distributed in 1998 include the Ten Year Plan for the Portsmouth Gaseous Diffusion Plant, The Portsmouth Depleted Uranium Cylinder Management Program, and The Portsmouth Environmental Bulletin.

\section{ENVIRONMENTAL MONITORING}

Environmental monitoring systems at DOE/PORTS include modeling of air emissions and sampling of surface water discharges. Modeling of the radionuclide emission sources at DOE/PORTS includes the X-326 L-Cage glove box and the X-744G glove box. Three sampling locations monitor direct discharges of water from DOE/PORTS sources to local surface waters.

The discharge of pollutants into the atmosphere from DOE/PORTS activities is regulated by permits from the State of Ohio. These pollutants include standard industrial pollutants (particulates, volatile organic compounds, and combustion byproducts) and airborne radionuclides.

Less than 9 tons of non-radiological pollutants (sulfur dioxide, nitrogen oxides, organic compounds, and particulates) are emitted to the air annually by DOE/PORTS based on the 1996-1997 Non-Title V Air 
Emissions Fee Report prepared in 1998. A total of 0.00016 curie (Ci) of radionuclides was discharged to the air in 1998.

Nonradiological constituents in liquid effluents are regulated by the NPDES permit and are routinely monitored. Nonradiological discharges from DOE NPDES outfalls are best summarized by the extent of compliance with the NPDES permit limits. The NPDES compliance rate for DOE outfalls was $100 \%$ for 1998.

Radiological analyses are also performed at NPDES sampling locations. A calculated total of $1.86 \mathrm{~kg}$ of uranium was discharged from DOE NPDES outfalls. Total radiological discharges from DOE NPDES outfalls were well below all applicable U.S. EPA and DOE standards.

\section{DOSE}

The maximum estimated potential dose to a member of the public from radiation from the DOE/PORTS depleted uranium cylinder yards is less than $0.5 \mathrm{mrem} / \mathrm{year}$. The maximum potential committed effective dose equivalent that a person living off site could receive from airborne radiological releases from $D O E$ activities at PORTS during 1998 is $0.00025 \mathrm{mrem} /$ year. These doses are much lower than the applicable U.S. EPA standard of $10 \mathrm{mrem} /$ year from the National Emission Standards for Hazardous Air Pollutants and the DOE standard of $100 \mathrm{mrem} /$ year from all sources. Additionally, these doses are much lower than that from background radiation (see Fig. 2), which is believed by the scientific community to have inconsequential health effects, if any, on humans. Therefore, the potential doses calculated to result from DOE/PORTS operations are not significant to

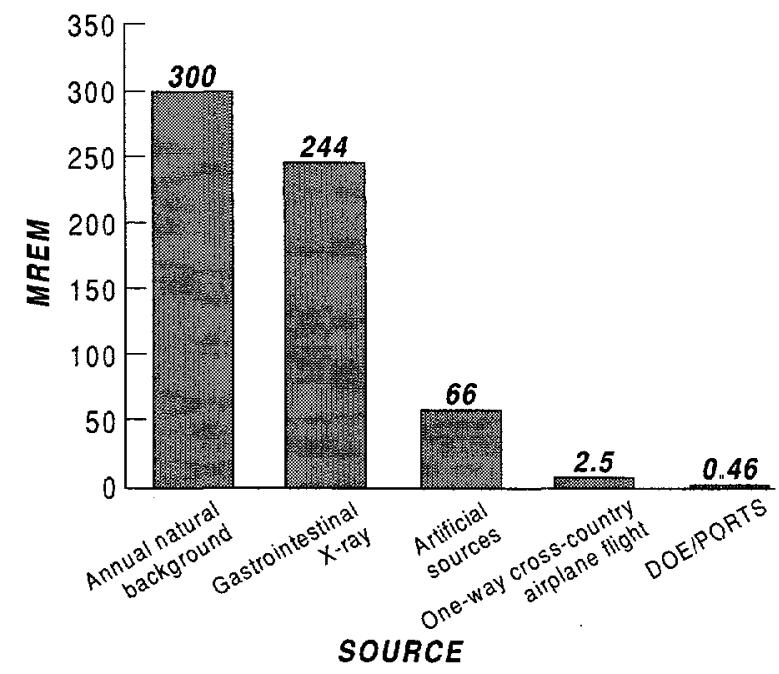

Fig. 2. Comparison of dose from various common radiation sources. public health.

\section{GROUNDWATER}

The groundwater monitoring program at PORTS includes RCRA hazardous waste units, solid waste disposal units, RCRA corrective action projects, special investigations, and surveillance monitoring. Groundwater monitoring is accomplished by collecting samples of water from approximately 200 monitoring wells installed at PORTS. Samples are analyzed for chemical and radiological constituents, and the resulting data is used to identify and monitor groundwater contamination.

Five groundwater contamination plumes have been identified onsite at PORTS. The primary groundwater contaminant is trichloroethene. Remediation of groundwater is being addressed under Ohio EPA's RCRA Corrective Action Program.

Surveillance monitoring also takes place to demonstrate that PORTS operations have not affected offsite water supplies. Water samples are collected from locations at the perimeter of the site and from residential water supplies and then analyzed to verify that contaminants at PORTS have not migrated off site. Results of the surveillance monitoring program indicate that PORTS has not affected groundwater quality outside the site boundaries. 


\section{QUALITY ASSURANCE AND QUALITY CONTROL}

Data reliability is of the utmost importance for monitoring releases and measuring radiation in the environment. To demonstrate that the monitoring and measurement results are accurate, DOE/PORTS has implemented a quality assurance and quality control program based on guidelines from the U.S. EPA, the American Society for Testing and Materials, and other federal and state agencies. The DOE/PORTS staff administers numerous quality control programs to verify reliability of the data on a day-to-day basis.

DOE/PORTS also participates actively in quality control programs administered by agencies outside the site such as the U.S. EPA. In 1998, DOE/PORTS participated in a U.S. EPA study to evaluate the analytical and reporting ability of laboratories that routinely perform analyses required by NPDES permits. DOE/PORTS uses the USEC Portsmouth Analytical Laboratory for all NPDES sampling. The results of the study were satisfactory. 


\title{
1. Site and Operations Overview
}

\begin{abstract}
The Portsmouth Gaseous Diffusion Plant (PORTS) is located on a 5.8-square-mile site in a rural area of Pike County, Ohio. U.S. Department of Energy (DOE) activities at PORTS include environmental restoration, waste management, removal of highly enriched uranium, and operation of nonleased facilities. Production facilities for the separation of uranium isotopes are leased to the United States Enrichment Corporation (USEC). USEC activities are not covered by this document.
\end{abstract}

\section{INTRODUCTION}

PORTS is owned by DOE. Effective July 1, 1993, DOE leased the production facilities at the site to USEC, which was established by the Energy Policy Act of 1992. Lockheed Martin Utility Services managed and operated the leased facilities for the USEC through May 17, 1999, at which time USEC assumed these responsibilities. Through March 31, 1998, Lockheed Martin Energy Systems was the management and operating contractor for DOE responsibilities, which included primarily environmental restoration, waste management, removal of highly enriched uranium, and operation of nonleased facilities at the plant (DOE/PORTS). DOE awarded Bechtel Jacobs Company LLC a 5 1/2-year management and integration contract on December 18, 1997. On April 1, 1998, Bechtel Jacobs Company assumed these responsibilities.

This report is intended to fulfill the requirements of DOE Order 5400.1, General Environmental Protection Program. The data and information contained in this report are in accordance with the Environmental Monitoring Plan (POEF-LMES-107, Lockheed Martin Energy Systems 1996) approved by DOE. This report is not intended to present all of the monitoring data at PORTS. Additional data collected for other site purposes, such as environmental restoration and waste management, are presented in other documents that have been prepared in accordance with applicable laws. These data are available through other mechanisms.

\section{DESCRIPTION OF SITE LOCALE}

DOE/PORTS is located in a rural area of Pike County, Ohio, on a 5.8-square-mile site (see Fig. 1.1). The site is 2 miles east of the Scioto River in a small valley running parallel to and approximately

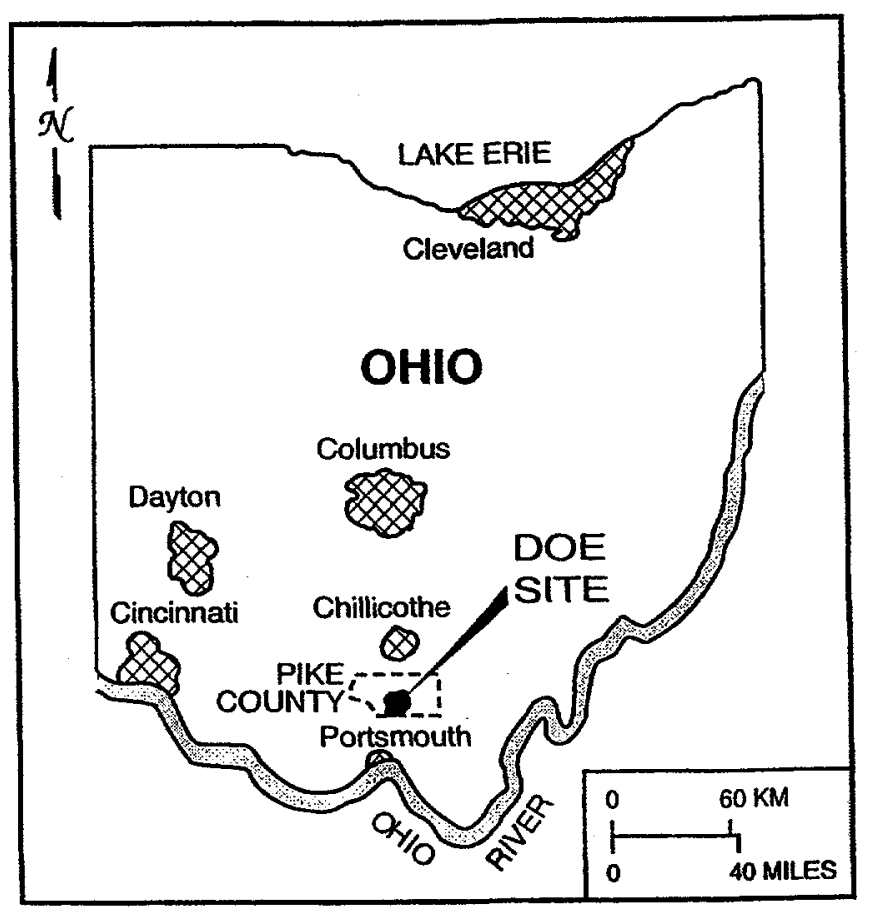

Fig. 1.1. Location of PORTS within the State of Ohio 


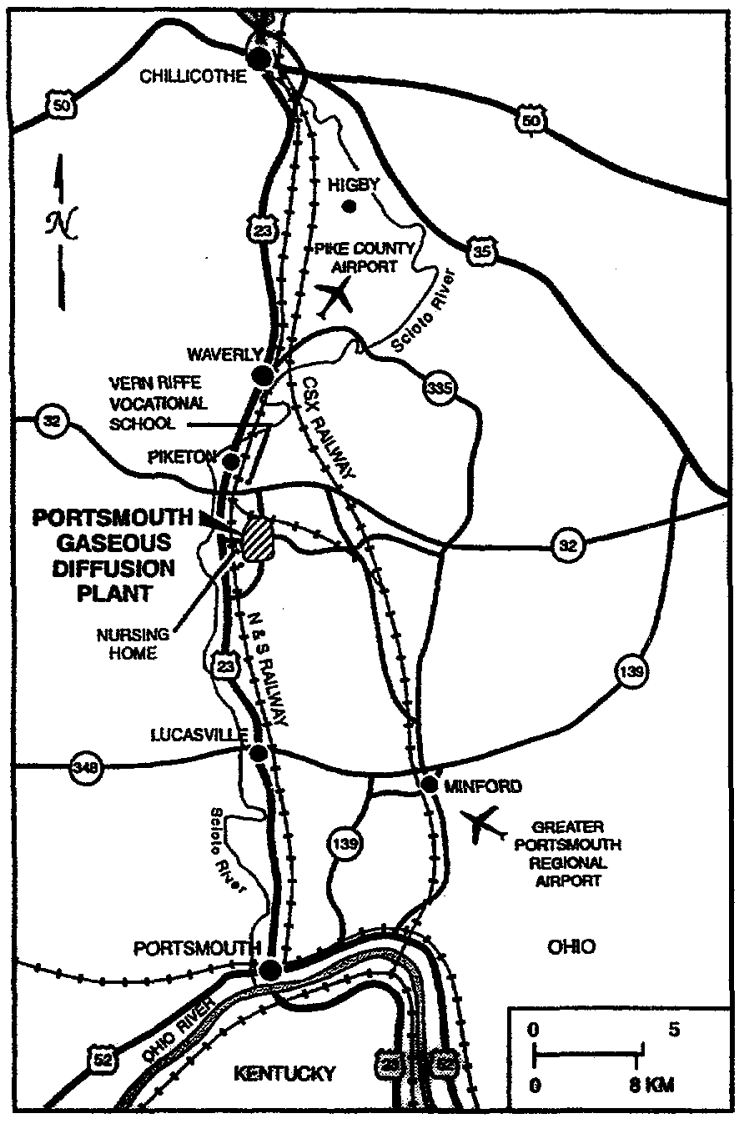

Fig 1.2. Location of PORTS in relation to the geographic region.
120 feet above the Scioto River floodplain. Fig. 1.2 depicts the plant site and its immediate environs.

Pike County has approximately 24,250 residents. Scattered rural development is typical; however, the county contains numerous small villages such as Piketon, Wakefield, and Jasper, that lie within a few miles of the plant. The county's largest community, Waverly, is about 10 miles north of the plant and has a population of about 4,500 residents. The nearest residential center in this area is Piketon, which is about 5 miles north of the plant on U.S. Route 23 ; its population is about 1,700 . Several residences are adjacent to the southern half of the eastern boundary and along Wakefield Mound Road (old U.S. 23), directly west of the plant. One nursing home, with a capacity of 36 persons, is located along Wakefield Mound Road.

Additional population centers within 50 miles of the plant are Portsmouth (population 22,249), 27 miles south; Chillicothe (population 21,923), 27 miles north; and Jackson (population 6,144), 18 miles east.

\section{DESCRIPTION OF SITE OPERATIONS}

DOE, through its managing contractor, operates the environmental restoration, waste management, and highly enriched uranium removal programs at the plant, as well as other nonleased DOE property. The environmental restoration staff perform remedial

investigations to define the nature and extent of contamination, evaluate the risk to public health and the environment, and determine the available alternatives from feasibility studies of potential remedial actions for sites under investigation. The goal of the environmental restoration program is to verify that releases from past operations and waste management at DOE/PORTS are thoroughly investigated and that remedial action is taken to protect human health and the environment.

The waste management program is responsible for managing wastes generated at the site. Wastes must be identified and stored in accordance with all environmental regulations. The waste management program also arranges transportation and off-site disposal of wastes. The goal of the waste management program is to manage waste from the time it is generated to its ultimate treatment, recycling, or disposal in accordance with all applicable regulations.

The goal of the highly enriched uranium removal program is to remove all highly enriched uranium from PORTS. The managing contractor is also responsible for maintaining a safe and regulatory compliant infrastructure at all non-leased buildings and administering the lease with USEC. 


\title{
2. Environmental Compliance
}

\begin{abstract}
DOE/PORTS is required to operate in accordance with environmental regulations established by federal and state laws, executive orders, DOE Orders, and compliance agreements. This section summarizes DOE/PORTS compliance status with regard to these various authorities.
\end{abstract}

\section{INTRODUCTION}

Responsibility for implementing environmental compliance at PORTS is divided between DOE, the site owner, and USEC. USEC is responsible for compliance activities directly associated with the operations that are leased from DOE, including air emission permits for uranium enrichment facilities and water discharge permits for several holding ponds and water treatment facilities. USEC is also responsible for the management of wastes generated by current enrichment operations. DOE retains responsibility for "legacy" wastes, which contain constituents such as asbestos and polychlorinated biphenyls that were used in DOE operations and became prohibited from use by law prior to the lease agreement. DOE is also responsible for the environmental restoration program, waste management program, removal of highly enriched uranium, and operation of all nonleased facilities.

DOE/PORTS has been issued a National Pollutant Discharge Elimination System (NPDES) permit for discharge of water to surface streams, several air emission permits, and a Resource Conservation and Recovery Act (RCRA) Part B permit for the storage of hazardous wastes. Appendix B provides a list of the active DOE/PORTS environmental permits for 1998.

Several federal, state, and local agencies are responsible for enforcing environmental regulations at DOE/PORTS. Primary regulatory agencies are the U.S. Environmental Protection Agency (U.S. EPA), Ohio Environmental Protection Agency (Ohio EPA), and Ohio State Fire Marshal's Office. These agencies issue permits, review compliance reports, conduct joint monitoring programs, inspect facilities and operations, and oversee compliance with applicable regulations.

DOE/PORTS conducts self-assessments to identify environmental issues and consults the regulatory agencies to identify the appropriate actions necessary to achieve and maintain compliance.

\section{COMPLIANCE PROGRAMS}

\section{Ohio Consent Decree and U.S. EPA Administrative Consent Order}

A Consent Decree with the State of Ohio, issued on August 29, 1989, and an Administrative Consent Order with the U.S. EPA, issued on September 29, 1989 (amended in 1994 and 1997), require the investigation and cleanup of surface water and air releases, groundwater contamination plumes, and solid waste management units. PORTS was divided into four quadrants based on groundwater flow patterns to facilitate the expedient cleanup of contaminated sites in accordance with RCRA corrective action and closure requirements. The Environmental Restoration Program at PORTS addresses requirements of the Ohio Consent Decree and U.S. EPA Administrative Consent Order. Chapter 3 provides additional information on the Environmental Restoration Program. 


\section{Resource Conservation and Recovery Act}

RCRA regulates the generation, accumulation, storage, transportation, and disposal of hazardous wastes. Wastes are designated as hazardous by the EPA because of various chemical properties, including ignitibility, corrosivity, reactivity, and toxicity.

\section{Hazardous Waste}

DOE/PORTS is permitted by Ohio EPA to store hazardous waste in the X-7725 and X-326 facilities. The permit, often called a Part B Permit, was issued to DOE/PORTS in 1995. In accordance with the permit, DOE/PORTS conducts weekly inspections of the permitted facilities for the following items: cracks in the floors, rain or surface water leaks, container labeling and condition, and availability of personal protective equipment. A quarterly noncompliance report is submitted to the Ohio EPA on the $15^{\text {th }}$ of January, April, July, and October.

On June 25, 1998, Ohio EPA conducted an inspection of the RCRA storage facilities and operating record for compliance with RCRA requirements. A Notice of Violation was issued on July 8, 1998, because weekly inspections of the X-622 hazardous waste accumulation area were not adequately maintained and the closure of that accumulation area was not in accordance with Ohio regulations. Corrective actions were implemented and Ohio EPA determined that the Notice of Violation was abated on August 19, 1998, and DOE had regained compliance.

RCRA also requires closure of areas formerly used to store hazardous waste. As of December 31, 1998, certification of closure had been received from Ohio EPA for 18 RCRA facilities. Ohio EPA approval of the X-740 waste oil facility and tank closure certification was received on April 23, 1998. DOE/PORTS also closed the trap material storage area in the X-326 building in 1998. Table 2.1 shows the current RCRA facility closure status.

The Ohio EPA has designated five RCRA units at PORTS as "integrated units." Preliminary remedial action at these sites has been completed as required by closure plans and as directed by the Ohio EPA. Final remediation of the units will be addressed in an Ohio EPA Director's Findings and Orders. A schedule will be developed and implemented to facilitate the timely and efficient remediation of the units. Table 2.1 provides a list of these integrated units.

RCRA requires groundwater monitoring at hazardous waste units. These units are the $\mathrm{X}-231 \mathrm{~B}$ southwest oil biodegradation plot, X-616 chromium sludge surface impoundments, X-701B holding pond, X701C neutralization pit, X-735 RCRA landfill (northern portion), and X-749 contaminated materials storage yard (northern portion). Additional monitoring is required at two units identified under the RCRA Corrective Action Program: the X-749B Peter Kiewit Landfill and the X-611A Lime Sludge Lagoons. Chapter 6 provides details of the groundwater monitoring programs for these units.

\section{Solid Waste}

In 1998, the X-735 industrial solid waste landfill was closed in accordance with the approved closure plan. Closure of the landfill was approved by Ohio EPA on December 28, 1998. The landfill, which was licensed by the Pike County Health Department, disposed of nonhazardous wastes generated at PORTS. These wastes included cafeteria, industrial, and disinfected medical wastes (except drugs), construction and demolition debris, and asbestos (in designated locations). Asbestos disposal was conducted in accordance with state and federal regulations. No hazardous wastes or radioactive wastes above $30 \mathrm{piC} / \mathrm{g}$ were disposed in the landfill. 
Table 2.1. RCRA facility status at DOEJPORTS for 1998.

\begin{tabular}{|c|c|}
\hline Status & Facility \\
\hline Certification of closure received from the Ohio EPA as of December 31,1998 & $\begin{array}{l}\text { X-744G(U) container storage facility } \\
\text { X-735 landfill (cells 1-6) } \\
\text { X-616 surface impoundments } \\
\text { X-705A incinerator } \\
\text { X-749 landfill (northern portion) } \\
\text { X-749 landfill (southern portion } \\
\text { X-750 waste oil tank } \\
\text { X-752 container storage facility } \\
\text { X-700 tank } 6 \text { generator closure } \\
\text { X-700 chromic acid tank } 7 \\
\text { X-700 tank } 8 \text { generator closure } \\
\text { X-744G(R) container storage facility } \\
\text { X-749A classified landfill } \\
\text { X-344A settling tank } \\
\text { X-740 waste oil facility } \\
\text { X-740 tank } \\
\text { X-735 industrial solid waste landfill } \\
\text { X-326 trap material storage area (DMSA \#7) }\end{array}$ \\
\hline Designated as an "Integrated Unit" by the Ohio EPA & $\begin{array}{l}\text { X-231B biodegradation plot } \\
\text { X-744Y container storage } \\
\text { X-701B surface impoundments } \\
\text { X-701C neutralization pit } \\
\text { X-230J7 holding pond }\end{array}$ \\
\hline
\end{tabular}

The Ohio Solid Waste regulations, Ohio Administrative Code 3745-29-10, require groundwater monitoring to detect releases from solid waste disposal sites. Two closed solid waste disposal facilities are monitored under the solid waste program: the X-735 Industrial Solid Waste Landfill and X-749A Classified Materials Disposal Facility. Chapter 6 provides groundwater monitoring information for these units.

\section{Federal Facility Compliance Act}

DOE/PORTS currently stores waste that is a mixture of RCRA hazardous waste and low-level radioactive waste. RCRA hazardous waste is subject to Land Disposal Restrictions, which do not allow the storage of hazardous waste for longer than one year. The Federal Facility Compliance Act, enacted by Congress in October 1992, allows for the storage of hazardous and low-level radioactive waste for longer than one year, because treatment for this type of waste is not yet available. The Act also requires federal facilities to develop and submit site treatment plans for treatment of mixed wastes. On October 4, 1995, a Director's Findings and Orders was issued by the Ohio EPA to implement the Federal Facility Compliance Act, allowing storage of mixed waste beyond one year and approving the DOE/PORTS Proposed Site Treatment Plan. The Site Treatment Plan Annual Report for Mixed Wastes at the Portsmouth Gaseous Diffusion Wastes at the Portsmouth Gaseous Diffusion Plant was submitted to the Ohio EPA on December 17, 1998, in accordance with Section V, Orders, Part C, Annual Report of the Director's Final Findings and Orders.

\section{Comprehensive Environmental Response, Compensation, and Liability Act}

DOE/PORTS is not on the Comprehensive Environmental Response, Compensation, and Liability Act National Priorities List of sites requiring cleanup, but is regulated under the provisions of the Comprehensive 
Environmental Response, Compensation, and Liability Act by the U.S. EPA Administrative Consent Order. U.S. EPA and Ohio EPA have chosen to oversee environmental remediation activities at DOE/PORTS under the RCRA Corrective Action Program.

Section 103 of the Comprehensive Environmental Response, Compensation, and Liability Act requires notification to the National Response Center if hazardous substances are released to the environment in amounts greater than or equal to the reportable quantity. Reportable quantities are listed in the act and vary depending on the type of hazardous substance. During 1998, DOE/PORTS had no reportable quantity releases of hazardous substances subject to Section 103 notification requirements.

\section{Toxic Substances Control Act}

The electrical power system at PORTS, which is leased by USEC, uses oil-blast circuit breaker transformers and large high-voltage capacitors, both containing polychlorinated biphenyl oil, to supply electricity to the enrichment cascade, as permitted under the Toxic Substances Control Act. USEC leases 147 oil-blast circuit breaker transformers and 11,101 large capacitors from DOE.

In February 1992, a federal facilities compliance agreement between DOE and U.S. EPA addressing polychlorinated biphenyl issues became effective and resolved several compliance issues. These issues included the use of polychlorinated biphenyls in systems that are not totally enclosed, storage of polychlorinated biphenyl radioactive waste in accordance with nuclear criticality safety requirements, and storage of polychlorinated biphenyl radioactive waste for longer than one year. The agreement required installation of troughs under motor exhaust duct gaskets located in production facilities to collect polychlorinated biphenyl oil leaks. When leaks or spills of polychlorinated biphenyl material occur, they are managed in accordance with the federal facilities compliance agreement. As of the end of 1998, DOE/PORTS was in compliance with the requirements and milestones of this federal facilities compliance agreement.

DOE/PORTS operates a number of storage areas for polychlorinated biphenyl wastes. The storage areas meet all applicable requirements of Title 40 Code of Federal Regulations Part 761.65 and the federal facilities compliance agreement. All PORTS solid polychlorinated biphenyl wastes are in long-term storage because of the lack of commercial disposal facilities authorized to dispose of wastes containing both polychlorinated biphenyls and radionuclides.

An annual report of progress made toward milestones specified in the federal facilities compliance agreement is compiled and submitted to the U.S. EPA. In addition, DOE and U.S. EPA representatives meet to resolve any unanticipated issues or uncertainties regarding the terms of the agreement.

Other sections of the Toxic Substances Control Act have little or no impact on DOE/PORTS. Although friable asbestos, which deteriorates into airborne fibers, is regulated under the Toxic Substances Control Act, the specific regulations applicable to PORTS are duplications of other state and federal regulations, specifically, the National Emission Standards for Hazardous Air Pollutants. DOE/PORTS also responds to U.S. EPA requests for health and safety data as required by the Toxic Substances Control Act, but because the site neither imports chemicals nor manufactures, processes, or distributes chemical substances for commercial purposes, such responses are generally negative.

\section{Clean Air Act}

DOE/PORTS had 4 permitted and 10 registered air emission sources at the end of 1998 (see Appendix B). Two of the permitted sources are currently involved in an appeal with Ohio's Environmental Board of Review. Six other air emissions permits held by DOE/PORTS that required renewal in 1998 were allowed to expire because the sources were no longer operable. No violations of air permit limits occurred during 1998.

An air source Permit to Install application and fee were submitted to the Ohio EPA in June 1997 for the construction of a cap on the Peter Kiewit landfill. Construction activities began on July 15, 1997, in

\section{2-4 Environmental Compliance}


accordance with the permit to install requirements. The project was completed in September 1998 and the permit was canceled.

\section{Clean Air Act, Title Vl, Stratospheric Ozone Protection}

As part of the Stratospheric Ozone Protection Plan, DOE has instituted a record-keeping system consisting of forms and labels to comply with the Title VI record-keeping and labeling requirements. These requirements affect all areas that use ozone-depleting substances in units or devices. The appliance service record and retrofit or retirement plan forms apply to units with a capacity of more than 50 pounds. The refrigeration equipment disposal log and associated appliance disposal label are used by all units regardless of capacity. More than 140 air conditioning/refrigeration units and 34 motor vehicle air-conditioning units under DOE control have been identified. Maintenance and service of these units is conducted under contract with USEC. The contractor technicians who service the equipment have been trained in accordance with U.S. EPA requirements.

\section{National Emission Standards for Hazardous Air Pollutants}

The National Emission Standards for Hazardous Air Pollutants require PORTS to submit an annual estimate of radiological emissions from DOE/PORTS sources. Gaseous radiological emissions from the X$326 \mathrm{~L}-$ Cage glove box and the X-744G glove box are modeled rather than monitored. Radiological air emissions from DOE/PORTS in 1998 were calculated at 0.00016 curie.

The U.S. EPA conducted an inspection of DOE/PORTS radiological air emission sources for compliance with National Emission Standards for Hazardous Air Pollutants on October 22, 1998. There were no findings as a result of the inspection.

\section{Clean Water Act}

The DOE/PORTS NPDES permit, issued in 1995 and modified in 1996 and 1997, encompasses six monitored outfalls. Three of the outfalls are classified as point-source discharges to waters of the state, and the other three outfalls are internal outfalls classified as effluents. Water from these three internal outfalls is treated in the USEC sewage treatment plant before reaching waters of the state. The annual inspection of all DOE/PORTS outfalls was conducted by Ohio EPA on March 25, 1998. No problems were noted during the inspection.

An NPDES permit renewal application was submitted to Ohio EPA on September 23, 1998, in accordance with the current permit that requires submittal of a permit renewal application at least 180 days prior to expiration of the current permit (March 31, 1999). The old permit will remain in effect until a new permit is issued by Ohio EPA.

Compliance rates (by individual parameter) at all DOE outfalls were $100 \%$. The overall DOE compliance rate for 1998 was also $100 \%$. The compliance rate is calculated by dividing the number of measurements that did not exceed the applicable permit limits by the total number of measurements made. None of the NPDES permit limits were exceeded during 1998.

\section{Underground Storage Tank Regulations}

The Underground Storage Tank Program is managed in accordance with the Ohio State Fire Marshal's Bureau of Underground Storage Tank Regulations codified in the Ohio Administrative Code, Chapter 1301:79. DOE/PORTS renewed the registration of 12 tanks in May 1998. DOE leases 11 of the underground storage tanks at the site to USEC and retains responsibility for 1 underground storage tank. 
During the fall of 1998, DOE removed its remaining tank. The Underground Storage Tank Closure Assessment Report for removal of the DOE tank at the southeast corner of X-7725 was submitted to the Bureau of Underground Storage Tank Regulations in January 1999.

\section{Emergency Planning and Community Right-To-Know Act}

The Emergency Planning and Community Right-To-Know Act of 1986, also referred to as the Superfund Amendments and Reauthorization Act Title III, requires reporting of emergency planning information, hazardous chemical inventories, and releases to the environment. Emergency Planning and Community Right-To-Know Act reports are submitted to federal, state, and local authorities.

Section 304 of the Emergency Planning and Community Right-To-Know Act requires reporting of off-site reportable quantity releases to state and local authorities. During 1998, DOE/PORTS had no reportable quantity releases.

The Hazardous Chemical Inventory Report, which includes the identity, location, storage information, and hazards of the chemicals that exceeded threshold planning quantities, is submitted annually to state and local authorities. Eight hazardous chemicals stored by DOE/PORTS exceeded the threshold planning quantities in 1998: aluminum oxide, diesel fuel, ethylene glycol, lithium hydroxide, polychlorinated biphenyls, sodium fluoride, triuranium octaoxide, and uranium hexafluoride.

The Toxic Chemical Release Inventory is sent annually to U.S. EPA and Ohio EPA. This report details releases to the environment of specified chemicals when they are manufactured, processed, or otherwise used in amounts that exceed threshold quantities specified by U.S. EPA. DOE/PORTS was required to report for two chemicals in 1998: ethylene glycol and zinc compounds. Fugitive air emissions of ethylene glycol were calculated at 3 pounds per year. Approximately 106 pounds of zinc was released from DOE/PORTS to surface waters (the west ditch and southwest ditch). An additional 93 pounds of zinc was released from the internal DOE/PORTS NPDES outfalls to the X-6619 Sewage Treatment Plant (a USEC NPDES permitted outfall).

\section{National Environmental Policy Act}

The National Environmental Policy Act requires evaluation of the environmental impacts of activities at federal facilities and of activities funded with federal dollars. Reviews are required for all projects to determine the potential for environmental impacts to the following:

- property (e.g., sites, buildings, structures, and objects) of historical, archaeological, or architectural significance, as officially designed by federal, state, or local governments, including properties eligible for listing on the National Register of Historic Places;

- potential habitat (including critical habitat) of federally listed endangered, threatened, proposed, or candidate species or of state-listed endangered and threatened species;

- floodplains and wetlands;

- natural areas such as federally and state-designed wilderness areas, national parks, national natural landmarks, wild and scenic rivers, coastal zones, state and federal wildlife refuges, and marine sanctuaries;

- prime agricultural lands; and

- special sources of water (such as sole-source aquifers, wellhead protection areas, and other water sources that are vital to a region).

\section{2-6 Environmental Compliance}


Reviews also consider impacts to air, surface water, groundwater, biota, socioeconomics, environmental justice, and worker safety and health.

DOE/PORTS has a formal program dedicated to compliance pursuant to DOE Order 451.1, National Environmental Policy Act Compliance Program. Restoration actions, waste management, enrichment facilities maintenance, and other activities are evaluated to determine the appropriate level of documentation. Documents are evaluated and approved internally. Environmental impact statements, however, must be produced by an independent organization. Routine operation and maintenance activities are also evaluated to assess potential environmental impacts. Most activities at PORTS qualified for a categorical exclusion as defined in Title 10 Code of Federal Regulations Part 1021, National Environmental Policy Act Implementing Procedures. These activities were judged to be routine and had no significant individual or cumulative environmental impacts.

In 1998, 23 record reports, which referenced 13 categorical exclusions, were generated for DOE/PORTS project activities. These project activities were part of the waste management and environmental restoration programs and consisted of activities such as the $\mathrm{X}-701 \mathrm{~B}$ process waste lines investigation, X-7725 roof repair, and X-344A soil disposal.

\section{Federal Insecticide, Fungicide, and Rodenticide Act}

Application of pesticides by DOE/PORTS and contractor personnel must be documented and approved by the DOE/PORTS pesticide coordinator. Plant personnel apply general-use pesticides according to product labeling, and all product warnings and cautions are strictly obeyed. When application of a restricteduse pesticide is required, a certified contractor is employed. No restricted-use pesticides were applied at DOE/PORTS in 1998.

\section{OTHER ENVIRONMENTAL ACTS AND FEDERAL REGULATIONS}

\section{Endangered Species Act}

The Endangered Species Act of 1973, as amended, provides for the designation and protection of endangered and threatened wildlife and plants, and the habitat on which such species depend. When appropriate, formal consultations are made with the U.S. Fish and Wildlife Service and the Ohio Department of Natural Resources. A sitewide threatened and endangered species habitat survey and an Indiana bat (Byosis sodalis) survey were completed in August 1996. No Indiana bats were found at PORTS. Few potential critical habitats were identified, and a report of the survey activities and results was provided to the Ohio Department of Natural Resources as required by the Federal Fish and Wildlife permit obtained to conduct the survey.

\section{National Historic Preservation Act}

The National Historic Preservation Act of 1966 is the primary law governing the protection of cultural resources (archaeological and historical properties). Cultural resource reviews are conducted on a case-bycase basis, and consultations with the Ohio State Historic Preservation Officer are made as required by Section 106 of the Act. A draft programmatic agreement among DOE, the Ohio State Historic Preservation Officer, and the Advisory Council on Historic Preservation concerning the management of historical and cultural properties at DOE/PORTS was submitted to the State Historic Preservation Officer for review and comment in 1997.

Phase I of the historical/archaeological survey was completed in September 1996. Fieldwork for Phase II of the project was completed in May 1997. Artifacts from the 1940s and 1950s were uncovered as 
well as remains from former dwellings that were present prior to construction of PORTS. Results from the survey will be coordinated with the State of Ohio Historic Preservation Office, and a Cultural Resources Management Plan will be developed.

\section{Archaeological and Historic Preservation Act and Archaeological Resources Protection Act}

The Archaeological and Historic Preservation Act and the Archaeological Resources Protection Act require the Secretary of the Department of Interior to report to Congress on various federal archaeological activities. The Archaeological Resources Protection Act requires federal land managers to provide archaeology program information to the Secretary of the Interior for this report. The Department of the Interior Questionnaire on Fiscal Year 1996 Federal Archaeological Activities at the Portsmouth Gaseous Diffusion Plant was completed and submitted to DOE Headquarters and forwarded to the Department of Interior in 1997 to satisfy this requirement.

\section{Farmland Protection Policy Act}

The Farmland Protection Policy Act of 1981 requires federal agencies to consider the effects of their proposed actions on prime farmland. Prime farmland is generally defined as land that has the best combination of physical and chemical characteristics for producing crops of statewide or local importance. When required, prime farmland surveys are conducted, and consultations with the U.S. Department of Agriculture's Natural Resources Conservation Service are made. No prime farmland surveys have been conducted at DOE/PORTS.

\section{Title 10 Code of Federal Regulations Part 1022, "Compliance with Floodplain/Wetlands Environmental Review Requirements"}

Part 1022 of Title 10 of the Code of Federal Regulations establishes policy and procedures for compliance with Executive Order 11988, Floodplain Management, and Executive Order 11990, Protection of Wetlands. The regulatory authority for wetlands is the United States Army Corps of Engineers. Activities (other than routine maintenance) proposed within 100-year and 500-year floodplains or in wetlands require publication of a notice of involvement in the Federal Register. For floodplains, a floodplain statement of findings summarizing the floodplain assessment is also required by DOE and must be published in the Federal Register for public comment at least 15 days prior to beginning the project. An assessment is also required for activity in a wetland prior to authorization to determine all effects of the proposed project. Many activities have been previously authorized by nationwide or regional permits and only require notification. Other activities qualify for abbreviated permit processing, whereby permission is granted via correspondence from the Corps of Engineers.

The sitewide wetland survey report was completed and submitted to the Corps of Engineers in 1996. There are 41 jurisdictional wetlands and 4 non-jurisdictional wetlands totaling 34.361 acres at PORTS. Activities in jurisdictional wetlands require a Clean Water Act Section 404 permit from the Corps of Engineers. No DOE activities required a Clean Water Act Section 404 permit during 1998. 


\section{DOE ORDERS}

\section{DOE Order 5400.1, General Environmental Protection Program}

DOE Order 5400.1 provides direction for compliance with the U.S. EPA, state, and local environmental regulations, and establishes requirements for internal environmental protection programs. DOE Order 5400.1 states that "it is DOE policy to conduct the Department's operations in compliance with the letter and spirit of applicable environmental statutes, regulations, and standards." The order recognizes that where U.S. EPA, state, and local environmental agencies "clearly exercise environmental protection authority through permitting and compliance administrative procedures applicable to DOE, they establish and regulate required performance for environmental protection."

DOE/PORTS environmental protection programs mandate the creation of several environmental reports. These reports include the 5-year plan required by the Office of Management and Budget Circular A106; the annual site environmental report; and reports for significant nonroutine releases of hazardous substances, consistent with DOE Order 232.1, Occurrence Reporting and Processing of Operations Information. The Environmental Protection Implementation Plan must be prepared and updated annually (if necessary). The DOE/PORTS Environmental Protection Implementation Plan (DOElORI11-1539\&D1, POEF-LMES-110) defines specific environmental objectives, including the means and schedules for accomplishing those objectives. The Environmental Monitoring Plan (POEF-LMES-107) defines a comprehensive system to provide effluent monitoring and environmental surveillance of effluents from DOE/PORTS. The Environmental Monitoring Plan is designed to meet federal and state regulatory requirements as well as those internal to DOE/PORTS. The Environmental Monitoring Plan must be prepared, reviewed annually, and updated every 3 years.

DOE Order 5400.1 defines environmental monitoring as consisting of effluent monitoring and environmental surveillance and establishes detailed requirements for both a groundwater protection management program and a groundwater monitoring program. DOE Order 5400.1 specifies the development of three individual documents relating to groundwater monitoring: an environmental monitoring plan (discussed previously), a groundwater protection program management plan, and a groundwater monitoring plan. The Groundwater Protection Program Management Plan formalizes and structures the DOE/PORTS groundwater protection program by identifying and assigning specific roles and responsibilities to the various staff. The Groundwater Protection Program Management Plan meets the requirements for a groundwater protection program as described in DOE Order 5400.1. The contents of this plan were updated in 1996 to reflect the following scope:

- purpose, policies, objectives, and history;

- regulations, requirements, and guidance applicable to groundwater monitoring;

- description of the hydrogeologic conditions and known groundwater contamination;

- groundwater monitoring procedures used to meet the applicable regulations;

- organization roles and responsibilities, including interfaces with other programs; and

- documentation required for projects.

The DOE/PORTS Groundwater Protection Program Management Plan is a dynamic document that allows updating of an individual section independently of the rest of the document. The plan must be reviewed annually, and revised and reissued every 3 years. Sections that are revised between reissue dates are numbered and dated. Where appropriate, the Groundwater Protection Program Management Plan incorporates material by reference; all referenced materials are subject to review, revision, and reissue.

The DOE/PORTS groundwater protection program characterizes the hydrogeology and monitors the groundwater quality at DOE/PORTS and its environs. Tasks are conducted in support of (1) environmental surveillance activities, (2) land disposal units requiring groundwater monitoring under hazardous waste regulations, (3) the remedial action program, and (4) land disposal units requiring groundwater monitoring 
under state solid waste regulations. Support for this program is provided in many forms, including technical advice and assistance, well installation and development, sampling and analysis, data management, data interpretation, report preparation, regulatory negotiation, and implementation of monitoring and corrective actions.

In addition to these general requirements, DOE Order 5400.1 contains recommendations regarding monitoring well construction and location, groundwater sampling frequency, sampling and analytical methods, sample sizes, and methods of sample preservation.

\section{DOE Order 5400.5, Radiation Protection of the Public and the Environment}

DOE Order 5400.5 provides guidance and establishes radiation protection standards and control practices designed to protect the public and the environment from undue radiological risk from operations of DOE and DOE contractors. The order requires that off-site radiation doses not exceed $100 \mathrm{mrem} /$ year above background.

The order establishes (1) a standard of high quality for DOE monitoring and surveillance programs, (2) authorized contamination limits for release of property, and (3) as-low-as-reasonably-achievable considerations. The order mandates consistency with drinking water criteria in 40 Code of Federal Regulations Part 141, National Interim Primary Drinking Water Regulations. The order also establishes derived concentration guides, or the concentration of radionuclides in water that under conditions of continuous exposure for one year by one exposure mode would result in an effective dose equivalent of 100 mrem. The order limits storm water and sanitary sewer discharge of radioactive effluents to groundwater. Finally, the order states that long-term management of groundwater shall be in accordance with legally applicable federal and state standards.

DOE/PORTS is well below all applicable media-specific dose limits, such as the U.S. EPA limit of 10 $\mathrm{mrem} / \mathrm{year}$ from airborne emissions and the DOE derived concentration guides for specific nuclides in wastewater and storm water discharges. DOE/PORTS conducts various modeling and dose assessment activities from samples and other information collected to address the potential for multiple-pathway exposures of the public. DOE/PORTS is in compliance with the requirements of this order.

\section{ENVIRONMENTAL PROGRAM INSPECTIONS AND VISITS}

During 1998, five inspections of the DOE/PORTS programs were conducted by federal, state, or local agencies. Table 2.2 summarizes the results of these inspections.

Table 2.2 Environmental inspections at DOE/PORTS for 1998.

\begin{tabular}{|c|c|c|c|}
\hline Date & Agency & Type & Findings \\
\hline March 25 & Ohio EPA & DOE/PORTS NPDES permit inspection & None \\
\hline April 24 & $\begin{array}{l}\text { Pike County Health Department } \\
\text { and Ohio EPA }\end{array}$ & $\begin{array}{l}\text { Inspection of closed solid waste facilities: X- } \\
\text { 749A Classified Materials Disposal Facility, } \\
\text { X-749 South Contaminated Materials Disposal } \\
\text { Facility, X-735 Industrial Solid Waste Landfill }\end{array}$ & None \\
\hline June 24 & Ohio EPA & RCRA compliance inspection & $\begin{array}{l}\text { See Notices of Violation } \\
\text { section }\end{array}$ \\
\hline September 30 & Pike County Health Department & $\begin{array}{l}X-735 \text { industrial solid waste landfill } \\
\text { inspection }\end{array}$ & None \\
\hline October 22 & U.S. EPA & Radiological NESHAP inspection & None \\
\hline
\end{tabular}


On October 13, 1998, the Ohio Native American Representatives and the Ohio EPA visited the site to discuss the Natural Resource Damage Assessment issues for DOE/PORTS. A general information briefing and a site tour were conducted by DOE/PORTS and Bechtel Jacobs Company. The possibility of setting aside a portion of land at PORTS for use by Native Americans was discussed. The Native American Representatives are continuing their evaluation of PORTS.

\section{Notices of Violation}

One Notice of Violation was issued to DOE/PORTS during 1998. On June 24 and 25, 1998, the Ohio EPA conducted a RCRA compliance inspection and issued a Notice of Violation as a result of the following:

- weekly inspections of the X-622 hazardous waste accumulation area were not adequately maintained; and

- the X-622 hazardous waste accumulation area was not closed in accordance with applicable regulations.

Corrective actions were implemented, and the Ohio EPA determined the Notice of Violation was abated on August 19, 1998. 


\title{
3. Environmental Programs
}

\begin{abstract}
Environmental Programs at DOE/PORTS include environmental restoration, waste management, waste minimization, pollution prevention, training, information exchanges, and public and employee awareness.
\end{abstract}

\section{ENVIRONMENTAL RESTORATION PROGRAM}

DOE established the Environmental Restoration Program in 1989 to identify and correct site contamination areas as quickly and cost-effectively as possible. The Environmental Restoration Program was granted an initial budget of $\$ 13.8$ million. In fiscal year 1994, Environmental Restoration Program expenditures peaked at $\$ 75.9$ million. The 1998 Environmental Restoration Program expenditures were $\$ 23$ million.

The Environmental Restoration Program addresses inactive sites through remedial action and deals with active facilities through eventual decontamination and decommissioning. Options for correcting or mitigating the contaminated sites and facilities include removal, containment, and treatment of contaminants. Because PORTS is a large facility, it is divided into four quadrants (Quadrant I, II, III, and IV) to facilitate the cleanup process.

The Environmental Restoration Program was established to fulfill the cleanup requirements of the Ohio Consent Decree and U.S. EPA Administrative Consent Order. The State of Ohio issued a Consent Decree on August 29, 1989, under the authority of RCRA Section 3008(h). U.S. EPA Region V issued an Administrative Consent Order on September 29, 1989, in accordance with RCRA and its implementing regulations; the Comprehensive Environmental Response, Compensation, and Liability Act of 1980; the National Contingency Plan; and applicable U.S. EPA policies.

As required by these enforcement actions, DOE/PORTS Environmental Restoration Program activities are conducted in accordance with the RCRA corrective action process, which consists of the following:

- Description of current conditions -- to provide knowledge of the groundwater, surface water, soil, and air.

- RCRA facility assessment -- to identify releases of contaminants and determine the need for further investigation.

- RCRA facility investigation -- to determine the nature and extent of any contamination.

- Corrective measures study -- to evaluate and select a remediation alternative. The Ohio Consent Decree requires a cleanup alternatives study, and the U.S. EPA Administrative Consent Order requires a corrective measures study. The Ohio EPA and U.S. EPA have agreed to a single document, the cleanup alternatives study/corrective measures study report, to fulfill the requirements for these essentially equivalent documents.

- Corrective measures implementation -- to implement the selected remediation measure.

- Interim remedial measures -- to implement quick remediation or mitigation measures prior to permanent action. 


\section{Cleanup Alternatives Study /Corrective Measures Study}

As required by the Consent Decree and the Administrative Consent Order, the cleanup alternatives studies/corrective measures studies identify the solid waste management units and explore the remedial alternatives within Quadrants I through IV. Following the approval of the final cleanup alternative studies/corrective measure studies, Ohio EPA selects the remedial alternatives that will undergo further review for determining the final remedial actions. Upon concurrence from the U.S. EPA and completion of the public review and comment period, the U.S. EPA and Ohio EPA select the final remedial actions for each quadrant. Ohio EPA issues a Decision Document to notify DOE/PORTS of the final remedial actions chosen for the site. DOE/PORTS is required to submit a corrective measures implementation plan that details the implementation of the final remedial actions listed in the Decision Document. Following the approval of the corrective measures implementation by the Ohio EPA, remedial action can begin.

The cleanup alternative study/corrective measure study for Quadrants III and IV were submitted to Ohio EPA in 1998. The cleanup alternative studies/corrective measure studies were approved for Quadrant III on July 13, 1998 and Quadrant IV on October 19, 1998. Development of the cleanup alternative studies/corrective measure studies for Quadrant I and II continued in 1998.

\section{Corrective Measures Implementation}

\section{X-749B Peter Kiewit Landfill}

The X-749B Peter Kiewit Landfill is located west of Big Run Creek just south of the X-230K holding pond. The landfill, opened in 1952, was used as the salvage yard, burn pit, and trash area during construction of the plant. After the initial construction, the disposal site was operated as a sanitary landfill until 1968, when soil was distributed over the site and graded, followed by seeding of the area with native grasses. No manifests or records exist to characterize the material in the landfill. In addition, construction details and operation records are not available.

In 1994, the portion of Big Run Creek next to the Peter Kiewit Landfill was relocated to the east side of the creek valley. An interceptor trench was installed in the former Big Run Creek channel to capture seeping water emanating from the eastern edge of the landfill. Contaminated water from the interceptor trench is processed at the X-622 groundwater treatment facility.

In 1995, the U.S. EPA approved the cleanup alternative studies/corrective measure study report for the construction of a RCRA Subtitle D cap on the Peter Kiewit Landfill. Pre-design studies for the project began in 1996. The corrective measures implementation work plan and pre-final design were submitted to and approved by the Ohio EPA. Construction of the cap began in mid-1997 and was completed on September 24, 1998. The Peter Kiewit Landfill Independent Engineer's Certification Report and the Final Operations and Maintenance Plan were submitted to the Ohio EPA on November 19, 1998. Ohio EPA approval of these documents was received on December 1, 1998. Results of groundwater monitoring at the X-749B Peter Kiewit Landfill are discussed in Chapter 6.

\section{X-700 Containment Tank/X-720 Neutralization Pit Removal}

In support of the Quadrant II cleanup alternatives study/corrective measures process, an investigation of the X-700 Containment Tank and X-720 Neutralization Pit was conducted between August 29, 1998 and September 10, 1998. The investigation examined the potential of the units to be contributing sources of soil and groundwater contamination, and the potential removal of these units. A meeting to discuss the remediation of the X-700 Containment Tank and X-720 Neutralization Pit was held on September 8, 1998 with Ohio EPA. The following remedial actions were agreed upon: 1) the X-700 Containment Tank would be 
grouted in place and 2) the X-720 Neutralization Pit and two feet of soil on all sides and beneath the unit would be excavated.

Field activities to grout the X-700 Containment Tank in place began on November 3, 1998 and were completed on November 4, 1998. Excavation of the X-720 Neutralization Pit began on November 3, 1998 and was completed on November 9, 1998. During excavation of the X-720 Neutralization Pit, it was determined that complete removal of the unit could potentially undermine the X-720 Maintenance Facility floor slab. Due to this safety concern, approximately $20 \%$ of the X-720 Neutralization Pit (the bottom and a portion of the pit in contact with the $\mathrm{X}-720$ foundation) was abandoned in place.

\section{Interim Remedial Measures}

An interim remedial measure was initiated on July 20, 1997 to contain seeps discovered south of the Peter Kiewit Landfill. Soil and bedrock characterization was completed on August 10, 1997, and a collection trench overlapping the existing system at the Peter Kiewit Landfill was installed in October 1997. Groundwater collected in the trench is being treated at the X-622 groundwater treatment facility.

Due to the physical location of the trench in relation to the Peter Kiewit Landfill, groundwater monitoring wells have been strategically placed in coordination with both the Peter Kiewit Landfill and the X749/X-120 interim remedial plume. Baseline sampling and monitoring sampling of the collection trench occurred during 1998. The results of these sampling events are found in the 1998 Annual Groundwater Report for the X-749B Peter Kiewit Landfill.

\section{Additional Cleanup Alternatives Study/Corrective Measures Study Activities}

\section{Sitewide Surface Drainage Ditches}

In 1997, a radiological contamination survey of sitewide drainage ditches was initiated. The areas investigated included the East Drainage Ditch, Big Run Creek, Southwest Drainage Ditch, North Drainage Ditch, and the Northeast Drainage Ditch.

\section{East Drainage Ditch Study}

A study of radiological contamination of the East Drainage Ditch, X-701B Plateau, and Former Retention Basins began in May 1997 and was completed August 1998. This study established the presence of radiological contamination in the study area and also established the necessary actions to prevent off-site migration of this contamination. The primary radiological contaminants investigated were technetium and uranium. Transuranics (americium-241, neptunium-237, plutonium-238, 239 and 240, thorium-228, 230, 232 , and 234) were also detected within the study area.

Laboratory analysis indicates americium-241, neptunium-237, plutonium-238, 239 and 240, and thorium-228, 230, 232, and 234 contamination is present at low detectable levels in the soil and perched water within the study area. Within the present site controls, there is no current threat from radiological contamination to site personnel or the environment. A final report of this study, Site Evaluation for the East Drainage Ditch, X-701B Plateau, and the Former Retention Basins (DOE/OR/11-3005\&D1, BJC/PORTS-59), was completed in October 1998 and is available at the Environmental Information Center. This area will be addressed and remediated as part of the RCRA Corrective Action process for Quadrant III. 


\section{Big Run Creek and Southwest Drainage Ditch Study}

Sampling of Big Run Creek and the Southwest Drainage Ditch began on August 23, 1997 and was completed on September 29, 1997. The Data Assessment and Risk Evaluation Report for Big Run Creek and the Southwest Drainage Ditch was submitted to Ohio EPA on March 17, 1998. The report indicates that no further action is required for these areas, and that the report will be discussed in the Quadrant I cleanup alternative study/corrective measures study.

\section{North Drainage Ditch Study}

Sampling of the North Drainage Ditch was initiated on December 1, 1997 and was completed on August 31, 1998. The Data Assessment and Risk Evaluation Report for the North Drainage Ditch Area was submitted to the Ohio EPA on November 11, 1998. The report indicates that no further remedial activity is currently required for this area.

\section{Northeast Drainage Ditch Study}

Sampling of the Northeast Drainage Ditch was initiated on June 4, 1998 and was completed on September 21, 1998. A Data Assessment and Risk Evaluation Report for the Northeast Drainage Ditch was prepared for submittal to the Ohio EPA in 1999.

\section{Technology Applications}

The DOE/PORTS Technology Applications Program was established in 1993 to facilitate the introduction of innovative or experimental environmental technology into the DOE/PORTS Environmental Restoration Program. The primary function of the technology program is to identify, evaluate, and test/demonstrate innovative advancements in environmental characterization and cleanup. The goal is to incorporate the most practical, cost-effective cleanup approaches as they are evolving for full-scale application at the plant. By combining conventional research and development with cleanup efforts, technology demonstrations enable the site to solve real problems using innovative methods. The Technology Applications Program utilizes a team of DOE contractors, national laboratory scientists, university researchers, private industries, site engineers, and technical staff.

\section{X-701B In Situ Chemical Oxidation}

In situ chemical oxidation is used to remediate contaminants such as trichloroethene in groundwater. With this technique, chemical oxidants are delivered to the subsurface to rapidly degrade organic contaminants. Laboratory experiments have demonstrated that potassium permanganate and hydrogen peroxide can effectively oxidize trichloroethene. Between the two oxidants, potassium permanganate is more stable and may result in a higher rate of trichloroethene degradation.

In 1996, researchers at the Oak Ridge National Laboratory in Oak Ridge, Tennessee proposed an oxidant delivery technique involving injection and recirculation of oxidant solution into a contaminated aquifer through multiple horizontal and vertical wells. In spring 1997, DOE/PORTS agreed to conduct a treatability study using in situ chemical oxidation through recirculation at the X-701B holding pond site.

The purpose of the demonstration was to assess the feasibility of recirculating strong oxidants to destroy volatile organic compound contaminants in situ at PORTS. The goals of the in situ chemical oxidation through recirculation were to:

- evaluate the process of delivering oxidants to saturated, permeable subsurface materials;

\section{3-4 Environmental Programs}


- assess the performance of the system in degrading contaminants within the aquifer; and

- obtain cost information for future applications at PORTS and other sites.

The in situ chemical oxidation through recirculation field demonstration took advantage of the existing infrastructure and extensive site characterization data generated from previous field demonstrations at X-701B. The in situ chemical oxidation through the recirculation field test was implemented using a pair of previously installed horizontal wells that transect an area of dense nonaqueous liquid contamination. In the demonstration, groundwater was extracted from one horizontal well, pumped to an existing groundwater treatment facility, dosed with potassium permanganate, and reinjected into a parallel horizontal well approximately $90 \mathrm{ft}$ away.

The initial results of the test indicate that in situ chemical oxidation through recirculation effectively oxidized trichloroethene in the saturated zone. Where the oxidant was found, trichloroethene levels were no longer detectable. Additional sampling for the demonstration occurred on January 13 and 14, 1998 (20 weeks after the demonstration) as part of a long-term assessment of the impacts of this technology. Additional modeling incorporating the sample results was performed, and the results indicated that the injection of oxidants remains a long-term treatment option for trichloroethene contamination.

\section{X-231A Soil Fracturing Demonstrations}

The active demonstration phase at X-231A began in August 1996 when four primary test cells (A through D) were established with hydraulic fractures. Each cell encompassed a subsurface region of approximately $30 \mathrm{ft}$ in diameter and up to $18 \mathrm{ft}$ below ground surface, and each was comprised of a set of stacked horizontal fractures. Test cell A consisted of sand propped fractures for injection of steam from an inwell steam generator and vapor extraction via overlying and underlying fractures. Test cell $\mathrm{C}$ contained ironmetal propped fractures to create a set of permeable barriers for interception and in situ destruction by reductive dechlorination. Test cell $\mathrm{D}$ was comprised of fractures that were placed and propped with a new permanganate particle grout. These stacked horizontal fractures were used to create a set of permeable reactive barriers for interception and in situ destruction by oxidation of organic compounds.

The X-231 A field activities were completed in September 1997. Sampling activities, data analysis, and reporting on the methods and results of the demonstration continued during 1998.

\section{X-625 Passive Groundwater Treatment through Reactive Media}

In 1996, DOE/PORTS constructed the X-625 facility for testing and research of reactive barrier technology for remediation of groundwater contaminated with trichloroethene under realistic field conditions. The facility consists of three parallel treatment trains that can accommodate canisters filled with reactive materials. Water is supplied to the facility from a horizontal well that collects trichloroethene-contaminated groundwater from the Gallia formation underlying the X-749/X-120 solid waste management unit.

A treatability study was conducted during 1996 to evaluate three reactive media materials: fine-grade iron filings, stock iron filings, and palladized iron filings. The results of this study showed that trichloroethene levels in the groundwater were degraded from about 50 to $150 \mu \mathrm{g} / \mathrm{L}$ to less than $5 \mu \mathrm{g} / \mathrm{L}$.

Additional studies were conducted in 1997 and 1998 to evaluate the applicability of reactive barriers at DOE/PORTS. The objectives of these studies were to predict the hydraulic life of reactive barriers, better understand what caused clogging of treatment canisters tested in 1996, and evaluate other reactive materials that may be used to remove trichlorothene from the groundwater. Peerless iron filings and Cercona foam were evaluated during 1998. Results indicated that trichloroethene continued to be degraded to less than $5 \mu \mathrm{g} / \mathrm{L}$. Both media operated with less detrimental effects from plugging than the media previously tested. 


\section{X-749/X-120 Vacuum Enhanced Recovery Wells}

High vacuum technology has been traditionally used for dewatering and stabilization of low permeability sediments or to speed dewatering of more permeable sediments; only recently has it been incorporated into groundwater remediation applications. The operating principle of vacuum enhanced recovery is based on the application of a vacuum that enhances the withdrawal of groundwater from a well and causes a steep groundwater gradient in the vicinity of the well.

The use of wells to remove water from an aquifer is one of the primary methods used for groundwater remediation. The standard technologies deployed in such operations have been successful in medium- and high-permeability geologic formations. The success of these standard technologies is significantly diminished in geologic formations with lower permeability due to restrictions in groundwater flow. Vacuum enhanced recovery systems are designed to overcome the limitations of standard remedial/recovery equipment by creating a pressure differential, which aids the movement of water in areas where gravity movement is limited by geology.

In addition to the enhanced recovery of fluids, the movement of air due to the applied vacuum also enhances the volatilization of chlorinated volatile organic compounds, which further aids the removal of such contaminants.

The X-749/X-120 groundwater plume was the selected site for this demonstration because this groundwater plume contains volatile organic compounds such as trichloroethene and trichloroethane, and this area also has low permeability soils. These conditions met the location requirements for the primary test objective, which was to demonstrate the effectiveness of vacuum enhanced recovery technology in reducing chlorinated volatile organic compounds in low permeability geologic formations. The secondary objective of the project was to collect information for the design of a full-scale implementation of the technology.

Field work for this project began on August 14, 1998 and was completed on December 4, 1998. In total, five vacuum-enhanced extraction wells were installed and tested during the project. A final report summarizing the project will be completed in 1999.

\section{5-Unit Area (Quadrant I Groundwater Investigative Area) Oxidant Injection}

The 5-Unit Area Oxidant Injection pilot project deployed an in situ chemical oxidant injection and recirculation process. The process involves recirculation of groundwater through four pumping wells located at fixed distances from a central injection well. The oxidant permanganate, as either potassium permanganate or sodium permanganate, is added to extracted groundwater that is then reinjected into the aquifer. The oxidant contained in the reinjected groundwater is expected to degrade contaminants.

The Ohio EPA and DOE/PORTS agreed to conduct a site-specific pilot project to provide additional data to facilitate the completion of the corrective measures study alternative development process for the remediation of the 5-Unit area. A second objective of the pilot project was to obtain data to determine the amount of contaminants removed by the project.

Field work for the project commenced in the vicinity of the X-770 facility on August 3, 1998 and continued through December 1998. Further field work will be conducted in the vicinity of the X-626 facility in 1999.

\section{X-701B Underground Steam Stripping and Hydrous Pyrolysis/Oxidation Project}

The X-701B Underground Steam Stripping and Hydrous Pyrolysis/Oxidation Project implements a process called dynamic underground steam stripping to extract subsurface volatile organic compounds in an area of contaminated groundwater. The process rapidly accelerates contaminant removal by injecting steam to the subsurface through multiple wells, thus heating the area to above the contaminants' boiling point. This heating vaporizes the compounds and drives them to centrally located vacuum extraction wells. By using a

\section{3-6 Environmental Programs}


process called hydrous pyrolysis oxidation in conjunction with steam stripping, contaminants not removed by the extraction wells can be destroyed in place by oxidation without further treatment.

Initial well installation for the project began on September 4, 1998 and was completed September 25, 1998. Installation of additional wells and monitoring equipment began on November 17, 1998 and was completed on December 15, 1998. Equipment mobilization and set-up began on December 2, 1998 with completion scheduled for January 1999. The treatment process was scheduled to begin in early 1999, upon completion of equipment setup.

\section{WASTE MANAGEMENT PROGRAM}

The DOE/PORTS Waste Management Program directs the safe storage, treatment, and disposal of waste generated by past and present operations and from current Environmental Restoration projects. DOE/ PORTS also stores USEC-generated waste in the RCRA Part B permitted storage areas. Waste managed under the program is divided into the following six categories, which are defined below:

- Low-level radioactive waste - radioactive waste not classified as high level or transuranic and that does not contain any components regulated by RCRA or the Toxic Substances Control Act.

- Hazardous waste - waste that contains one or more of the wastes listed under RCRA or that exhibits one or more of the four RCRA hazardous characteristics: ignitability, corrosivity, reactivity, and toxicity.

- Mixed waste - waste containing both hazardous and radioactive components. Mixed waste is subject to RCRA, which governs the hazardous components, and to additional regulations that govern the radioactive components.

- Polychlorinated biphenyl and polychlorinated biphenyl-radioactive wastes - waste containing polychlorinated biphenyls, a class of synthetic organic chemicals. Under Toxic Substances Control Act regulations, polychlorinated biphenyl manufacturing was prohibited after 1978. However, continued use of polychlorinated biphenyls is allowed, provided that the use does not pose a risk to human health or the environment. Disposal of all polychlorinated biphenyl materials is regulated.

- Asbestos waste - friable asbestos materials from renovation and demolition activities.

- Sanitary waste - solid waste, such as office waste, generated by commercial operations.

During 1998, approximately 2.54 million pounds of waste from PORTS were recycled, treated, or disposed (Table 3.1). Future waste management projects include the shipment for disposal of low-level radioactive waste and mixed waste, and the treatment of mixed and polychlorinated biphenyl/mixed waste at off-site commercial facilities.

Waste management requirements are varied and are sometimes complex because of the variety of waste streams generated by DOE/PORTS activities. DOE Orders, Ohio EPA regulations, and U.S. EPA regulations must be satisfied to demonstrate compliance for waste management activities. Additional policies have been implemented for management of radioactive, hazardous, and mixed wastes. These policies include the following:

- minimizing wastes;

- characterizing and certifying wastes before they are stored, processed, treated, or disposed;

- pursuing volume reduction and use of on-site storage when it is safe and cost-effective, until a final treatment and/or disposal option is identified; and

- recycling. 
Table 3.1 Waste management treatment, disposal, and recycling accomplishments for 1998 .

\begin{tabular}{|l|l|c|l|}
\hline \multicolumn{1}{|c|}{ Waste Stream } & \multicolumn{1}{|c|}{ Quantity } & \multicolumn{1}{c|}{$\begin{array}{c}\text { Treated, Disposed, or } \\
\text { Recycled }\end{array}$} & \multicolumn{1}{|c|}{$\begin{array}{c}\text { Treatment, Disposal, or } \\
\text { Recycling Facility }\end{array}$} \\
\hline $\begin{array}{l}\text { X-701B Interceptor Trench } \\
\text { Soils }\end{array}$ & 560 drums $/ 919,245 \mathrm{lbs}$ & Disposed & Envirocare \\
\hline Crushed Light Bulbs & $4,000 \mathrm{lbs}$ & Disposed & Envirocare \\
\hline Wastewater & $140,224 \mathrm{lbs}$ & Treated & On-site treatment facilities \\
\hline $\begin{array}{l}\text { X-705 Oil \& Grease } \\
\text { Removal Unit Sludge }\end{array}$ & $4 \mathrm{boxes} / 15,887 \mathrm{lbs}$ & Disposed & Envirocare \\
\hline $\begin{array}{l}\text { Mixed Waste and } \\
\text { polychlorinated biphenyl } \\
\text { liquids }\end{array}$ & $48,840 \mathrm{lbs}$ & Treated & $\begin{array}{l}\text { Toxic Substances Control } \\
\text { Act Incinerator }\end{array}$ \\
\hline Empty Drums & & Recycled & U.S. Ecology \\
\hline Office Paper & $420 \mathrm{drums} / 28,240 \mathrm{lbs}$ & Recycled & Rumpke \\
\hline Aluminum Cans & $33,220 \mathrm{lbs}$ & Recycled & Star, Inc. \\
\hline Cardboard & $1,581 \mathrm{lbs}$ & Recycled & Star, Inc. \\
\hline Light Bulbs & $8,320 \mathrm{lbs}$ & Recycled & $\begin{array}{l}\text { Superior Special Services, } \\
\text { Inc. }\end{array}$ \\
\hline Lead Bullets & $10,611 \mathrm{lbs}$ & Recycled & Cherrington Scrap Metal \\
\hline Brass Casings & $5,600 \mathrm{lbs}$ & Recycled & Cherrington Scrap Metal \\
\hline Scrap Metal & $12,800 \mathrm{lbs}$ & Recycled & Cherrington Scrap Metal \\
\hline
\end{tabular}

\section{WASTE MINIMIZATION AND POLLUTION PREVENTION PROGRAM}

DOE/PORTS has combined its waste minimization and pollution prevention efforts to consolidate related activities. The objectives of the DOE/PORTS Waste Minimization and Pollution Prevention Program include the following:

- fostering a philosophy to conserve resources and create a minimum of waste and pollution;

- promoting the use of nonhazardous materials in DOE/PORTS operations to minimize potential risks to human health and the environment;

- reducing or eliminating the generation of wastes through material substitution, product reformulation, process modification, improved housekeeping, and on-site recycling; and

- complying with federal and state regulations and DOE policies and requirements for waste minimization.

The DOE/PORTS Waste Minimization and Pollution Prevention Program continues activities to achieve the waste minimization objectives. Typical projects include the following:

- maintaining a comprehensive waste tracking and reporting system;

- evaluating DOE/PORTS processes and activities to identify waste minimization opportunities;

- maintaining an effective DOE/PORTS waste minimization training program;

- maintaining a waste minimization and pollution prevention awareness promotional campaign; and

- providing a waste minimization and pollution prevention information exchange network.

The Pollution Prevention Awareness Program consists of (1) pollution prevention awareness through Earth Day events, newsletters, bulletins, and memoranda; (2) awards, recognition for employees, and performance indicators; (3) information exchange; and (4) training. Other recognized pollution prevention 
measures are the Best Management Practices Plan and the Portsmouth Spill Prevention, Control, and Countermeasures Plan.

following:

Highlights of the Waste Minimization and Pollution Prevention Program in 1998 include the

- reusing excess computer equipment by donating it to public schools through the Southern Ohio Diversification Initiative;

- sending empty drums contaminated with radioactivity to a facility that will reuse them instead of contaminating clean drums;

- shipping over 1.3 million pounds of scrap metal (iron, aluminum, copper, lead, and brass) for recycling;

- emptying nearly 19,000 pounds of aerosol cans, preparing them for metal recycling, and removing them as a hazardous waste;

- participating in the Ohio Governor's Earth Day celebration at the state capital;

- providing sixth-grade students with lessons on using discarded materials for new purposes at the Environmental Fair;

- sending over 10,000 pounds of spent fluorescent light bulbs to a recycling facility;

- recycling more than 42,000 pounds of sanitary waste including office paper, corrugated cardboard, and aluminum cans;

- distributing the first two PORTS Pollution Prevention Program Achievement Awards for support of the local program;

- recycling more than 5,700 oversized pallets through the Southern Ohio Diversification Initiative rather than sending them to a landfill at a cost in excess of $\$ 10,000$;

- selling over $62,000,000$ pounds of lithium hydroxide monohydrate, which also precluded storing it as a RCRA waste at a cost in excess of $\$ 200,000,000$.

Activities planned for 1999 include initiating a comprehensive training program for Environmental Restoration activities to support the goals established in Executive Order 13101, continuing the scrap metal recycling program, recycling the inventory of spent incandescent light bulbs, implementing programs to prevent managing spent batteries and light bulbs as waste, conducting a Pollution Prevention Opportunity Assessment on low-volatile organic compound floor coverings for the RCRA storage area, and implementing routine tracking of hazardous materials through use of a chemical product inventory tracking data base purchased in 1997.

\section{ENVIRONMENTAL TRAINING PROGRAM}

DOE/PORTS provides environmental training to increase employee awareness of environmental activities and to enhance the knowledge and qualifications of personnel performing tasks associated with environmental assessment, planning, and restoration. The program includes on- and off-site classroom instruction, on-the-job training, seminars, and specialized workshops and courses. Environmental training conducted or prepared by DOE/PORTS includes the following: 
- hazardous waste training for workers;

- hazardous waste training for managers/supervisors; and

- RCRA training for treatment, storage, and disposal facility workers.

\section{INFORMATION EXCHANGE PROGRAM}

To improve and update its environmental monitoring and research programs, DOE/PORTS exchanges information within the site and with other DOE facilities and other sources of information. DOE/PORTS representatives attend both DOE-sponsored and independent technical information exchange workshop, such as the annual DOE Model Conference, quarterly multi-plant team meetings, and professional conferences.

\section{PUBLIC AWARENESS PROGRAM}

A comprehensive community relations and public participation program has been in place since early 1990. The purpose of the program is to foster a spirit of openness and credibility between PORTS officials and local citizens, elected officials, business, media, and various segments of the public. The program also provides the public with opportunities to become involved in the decisions affecting environmental issues at the plant.

DOE/PORTS opened a public Environmental Information Center in February 1993 to provide public access to all documents used to make decisions on remedial actions being taken at the plant. The inforrnation center is on the plant site in a modular unit outside the E-Vehicle portal. The mailing address for the Information Center is U.S. DOE Environmental Information Center, P.O. Box 693, Piketon, Ohio 45661. The street address is 3930 U.S. Route 23 South, Perimeter Road West, Piketon, Ohio 45661. Hours for the Information Center are 9 a.m. to 12 p.m. Monday and Tuesday, 12 p.m. to 4 p.m. Wednesday and Thursday, or by appointment (740-289-3317).

A group of about 45 key stakeholders, composed of elected officials, community leaders, environmentalists, and other individuals who have expressed an interest in the Environmental Restoration and Waste Management programs, is targeted for information and input on current activities and those actions under consideration at the plant. Semiannual public update meetings and public workshops on specific topics are also held to keep the public informed and to receive their comments and questions. Periodically, fact sheets about major projects are written for the public. Semiannual environmental bulletins are printed and distributed to more than 4,000 recipients, including those on the community relations mailing list, neighbors within 2 miles of the plant, and all plant employees and retirees.

Points of contact have been established for the public to obtain information or direct questions regarding the Environmental Restoration and Waste Management programs. The DOE Site Office may be contacted at 740-897-5521. The Bechtel Jacobs Company Public Affairs Manager (740-897-2336) also provides information on the program. 


\title{
4. Environmental Monitoring
}

\begin{abstract}
Environmental monitoring at DOE/PORTS involves monitoring air, surface water, and groundwater. Monitoring is based on critical pathway analyses, public concerns, measurement capabilities, and environmental regulations. Samples are analyzed for radiological contaminants as well as potentially harmful nonradiological pollutants. The release of airborne pollutants from DOE/PORTS is regulated by permits from the state of Ohio. The majority of liquid effluents from DOE/PORTS are regulated by the NPDES permit. A total of $0.0067 \mathrm{Ci}$ of radioactivity was released from NPDES permitted DOE/PORTS outfalls in 1998. For nonradiological releases, overall compliance with the NPDES permit limits was $100 \%$. Results for 1998 indicate that DOE/PORTS operations did not have a significant environmental impact inside or outside the reservation boundaries.
\end{abstract}

\section{INTRODUCTION}

DOE/PORTS practices a progressive environmental strategy for complying with the pollution control requirements of the Clean Air Act and the Clean Water Act. This strategy uses modern technology to decrease pollution coupled with continual review of treatment facility performance to meet current regulations for airborne and liquid releases in the most cost-effective manner. DOE/PORTS activities have historically contributed minimal pollutants to the environment.

This chapter summarizes environmental monitoring activities at DOE/PORTS. Environmental monitoring consists of two major activities: effluent monitoring and environmental surveillance. Effluent monitoring is direct measurement or the collection and analysis of samples of gaseous and liquid discharges to the environment. Environmental surveillance is direct measurement or the collection and analysis of samples of air, water, and soil. Environmental monitoring is performed to characterize and quantify contaminants and to demonstrate compliance with applicable standards and permit requirements.

The goal of the environmental monitoring program is to detect and assess the effects (if any) of DOE/ PORTS operations on human health and the environment. Multiple samples are collected throughout the year and are analyzed for radioactivity, chemical content, and various physical attributes. The results of these samples are used to gauge the environmental impacts of DOE/PORTS operations and to set priorities for further environmental improvements. The justification for choosing certain environmental media to be sampled, specific sampling locations, sampling frequencies, and parameters is referred to as the rationale. Environmental regulations, critical pathways analyses, public concerns, and measurement capabilities must all be considered in the rationale for the establishment of a successful environmental monitoring program. The rationale for the establishment of the DOE/PORTS environmental monitoring program is found in the Environmental Monitoring Plan for the Portsmouth Gaseous Diffusion Plant (POEF-LMES-107, Lockheed Martin Energy Systems 1996).

\section{Environmental Regulations}

Numerous state and federal regulations that encompass radiological and nonradiological programs determine much of the monitoring conducted at DOE/PORTS. These regulations include the National Emission Standards for Hazardous Air Pollutants, NPDES, and RCRA. Compliance with these regulations involves a number of regulators, including the U.S. EPA and the Ohio EPA, which oversee various site 
activities to help verify compliance. DOE Orders in the 5400 series, in particular 5400.1, General Environmental Protection Program, and 5400.5, Radiation Protection of the Public and the Environment, also address environmental requirements. Chapter 2 discusses DOE/PORTS compliance activities.

Acceptable levels of nonradioactive substances are generally specified in regulations or permits. Regulations for radioactive materials generally include limits for exposure to the public. Radioactive materials are regulated at the point of discharge and are monitored as they disperse into the surrounding environment. Most radionuclides are released in such small amounts, however, that it is not possible to detect them after they disperse into a medium such as air, water, soil, or vegetation. For this reason, DOE/PORTS uses U.S. EPA-approved mathematical models to estimate the transport and dispersion of radioactive contaminants in the environment and the resulting exposures to the off-site population, as discussed in Chapter 5. Models also help optimize the effectiveness of the existing radiological monitoring program. Modeling contributes to the best use of resources available for sampling and analysis and helps to verify that a sampling network is performing adequately.

Extensive monitoring is also conducted for nonradioactive contaminants. The nonradiological monitoring program is designed to demonstrate that the physical and chemical properties of air and liquid discharges comply with state and federal standards. Monitoring of atmospheric releases is designed to demonstrate compliance with permits issued by the Ohio EPA. Monitoring requirements for liquid effluents vary at each outfall, or discharge point, depending on the type of facility and the known characteristics of the wastewater.

\section{Critical Pathways Analysis}

Individuals can be exposed to airborne and liquid releases of radioactive and chemical materials through various routes referred to as pathways. Environmental reports are examined to determine which radionuclides and exposure pathways are most important in terms of the quantity of radionuclides released, the dose received by the maximally exposed individual, and the collective dose received by the population as a whole. This type of analysis, called a critical pathways analysis, helps determine which radionuclides and pathways at a particular site deserve the most attention. Critical pathway analyses have been used historically at DOE/PORTS as input for the environmental monitoring program. The following sections summarize the results of a critical pathways analysis of DOE/PORTS operations. The analysis includes radionuclide releases to the atmosphere and surface water, which are the principal media that could transport radioactive contaminants from the site.

Models are used to assess environmental impacts relating to the transport of radionuclides and chemicals, and to assess human exposures to these substances released from DOE/PORTS. Those pathways of exposure to the most-exposed individuals and to the entire population residing within 50 miles of DOE/PORTS are evaluated.

Each assessment is documented. A file is created that contains the results of each calculation, a description of models used, a description of any computer codes used to implement the models, and a complete list of the values and sources of all input data and assumptions used. Surface water and groundwater modeling are conducted as necessary to conform with applicable state and federal requirements.

Environmental monitoring practices are reevaluated as new methods and the need for monitoring evolve. Types of measurements and their frequencies are reviewed routinely, and monitoring locations are sometimes changed.

The Environmental Monitoring Plan for DOE Activities has been revised to address DOE/PORTS activities only. The plan, required by DOE Order 5400.1, was distributed in November 1996 . The plan documents DOE effluent monitoring and environmental surveillance activities conducted at DOE/PORTS. The plan also includes the rationale and design criteria for the environmental monitoring program, the frequency of monitoring and analysis, specific analytical and sampling procedures, quality assurance requirements, and guidance on preparing and distributing reports.

\section{4-2 Environmental Monitoring}




\section{AIRBORNE DISCHARGES}

Airborne discharges of radionuclides from DOE/PORTS are regulated under the Clean Air Act National Emission Standards for Hazardous Air Pollutants. These regulations set (1) an annual dose limit of $10 \mathrm{mrem} /$ year to any member of the public as a result of airborne radiological releases and (2) certain minimum performance standards for demonstrating compliance with the dose limit. Other atmospheric pollutants are regulated by Ohio EPA under Ohio Permit to Operate requirements for each permitted source.

In addition to these outside authorities, DOE regulates radionuclide emissions to all environmental media through DOE Orders 5400.1, General Environmental Protection Program, and 5400.5, Radiation Protection of the Public and the Environment. DOE Order 5400.5 sets an annual dose limit of $100 \mathrm{mrem} / \mathrm{year}$ for any member of the public. Unlike the National Emission Standards for Hazardous Air Pollutants limit of $10 \mathrm{mrem} /$ year, the DOE limit includes the impacts of radioactivity releases from a facility through all pathways.

DOE Order 440.1, Worker Protection Management for DOE Federal and Contractor Employees, DOE Order 441.1, Department of Energy Radiological Health and Safety Policy, and Title 10 Code of Federal Regulations Part 835, Occupational Radiation Protection, require DOE facilities to establish effluent monitoring programs to demonstrate that no unrecognized environmental impact occurs as a result of DOE operations. The details of the DOE/PORTS environmental monitoring program are documented in the Environmental Monitoring Plan for the Portsmouth Gaseous Diffusion Plant.

\section{Radiological Airborne Discharges}

DOE leases the enrichment operations facility at DOE/PORTS to USEC. Under the terms of the lease, USEC is responsible for most of the existing radionuclide point-source discharges. DOE/PORTS is responsible for the X-345 high-assay sampling area, the X-326 L-Cage glove box, and the X-744G glove box. The operating permit for the X-345 high-assay sampling area expired in 1998 and was not renewed. This source has been out of service for several years and will not be operated in the future. USEC sources are not included in this report.

\section{Radiological Air Sample Collection and Analytical Procedure}

Waste stream analyses have been performed on each material handled at the facility to determine which radionuclides are present. Radionuclide isotopes that have been identified and are currently used to determine the radiological airborne discharges and associated radiological dose to the public include actinium $\left({ }^{228} \mathrm{Ac}\right)$, americium $\left({ }^{241} \mathrm{Am}\right)$, beryllium $\left({ }^{7} \mathrm{Be}\right)$, bismuth $\left({ }^{214} \mathrm{Bi}\right)$, lead $\left({ }^{212} \mathrm{~Pb}\right.$ and $\left.{ }^{214} \mathrm{~Pb}\right)$, neptunium $\left({ }^{237} \mathrm{~Np}\right)$, plutonium $\left({ }^{238} \mathrm{Pu},{ }^{239} \mathrm{Pu}\right.$, and $\left.{ }^{240} \mathrm{Pu}\right)$, potassium $\left({ }^{40} \mathrm{~K}\right)$, protactinium $\left({ }^{233} \mathrm{~Pa}\right.$, ${ }^{234} \mathrm{~Pa}$, and $\left.{ }^{234 \mathrm{~m}} \mathrm{~Pa}\right)$, radium $\left({ }^{224} \mathrm{Ra}\right.$, ${ }^{226} \mathrm{Ra}$, and $\left.{ }^{228} \mathrm{Ra}\right)$, technetium $\left({ }^{99} \mathrm{Tc}\right)$, thallium $\left({ }^{208} \mathrm{Tl}\right)$, thorium $\left({ }^{228} \mathrm{Th},{ }^{230} \mathrm{Th},{ }^{231} \mathrm{Th},{ }^{232} \mathrm{Th}\right.$, and $\left.{ }^{234} \mathrm{Th}\right)$, and uranium $\left({ }^{234} \mathrm{U},{ }^{235} \mathrm{U},{ }^{236} \mathrm{U}\right.$, and $\left.{ }^{238} \mathrm{U}\right)$.

Dose estimate calculations for the X-326 and X-744G glove boxes are performed annually to demonstrate compliance with the radionuclide National Emission Standards for Hazardous Air Pollutants. Calculations are based on amounts of materials handled for each glove box in 1998 and the radionuclide characteristics of those materials.

\section{Radiological Air Estimation Results}

Radionuclide emissions from DOE/PORTS, all currently based on estimating procedures, had no significant impact on public health or the environment. There were no unplanned releases during 1998. DOE/ PORTS emission estimates still remain well below the applicable U.S. EPA standard and far below the levels listed as safe by national and international regulatory bodies such as the Occupational Safety and Health 
Administration, the Nuclear Regulatory Commission, and the International Committee on Radiation Protection. Radiological emissions from DOE/PORTS sources, depicted in curies (a measure of radioactivity), increased from $0.00014 \mathrm{Ci}$ in 1997 to $0.00016 \mathrm{Ci}$ in 1998 .

\section{Nonradiological Airborne Discharges}

Nonradiological releases to the atmosphere are permitted under the Ohio Permit to Operate regulations. Under Ohio regulations, the Ohio EPA can register small emission sources rather than issue a formal permit. Permits to operate must be renewed every 3 years and must set out explicit numerical limits on emission rates or operating restrictions and on monitoring and reporting requirements. A registration is valid until revoked by the Ohio EPA and presumes that the registered source is too small to have a significant environmental impact. Nonradiological sources at DOE/PORTS are either permitted or registered sources.

\section{Nonradiological Air Sample Collection and Analytical Procedure}

Emissions of nonradiological air pollutants at DOE/PORTS are estimated using various U.S. EPAapproved procedures. These procedures are used to estimate emissions from sources such as storage tanks and boilers.

\section{Nonradiological Air Estimation Results}

DOE/PORTS operates numerous small sources of conventional air pollutants such as nitrogen oxides, sulfur dioxide, and particulate matter. These emissions are estimated every 2 years for the Ohio EPA's biennial emission fee statement. This statement is required for facilities such as DOE/PORTS that are not subject to the federal operating permit program (Title V) under Title 40 Code of Federal Regulations Part 70. For the Biennial Non-Title V Emission Report, DOE/PORTS estimated emissions of sulfur dioxide, nitrogen oxides, organic compounds, and particulate matter to be less than 9 tons per year, which is well below the limit of 100 tons per year for Non-Title $V$ facilities.

The Toxic Chemical Release Inventory required by the Emergency Planning and Community Rightto-Know Act requires reporting of releases of certain chemicals specified by the U.S. EPA. In 1998, massbalance calculations indicated only ethylene glycol was emitted to the atmosphere at an estimated 3 pounds.

Another potential air pollutant present at DOE/PORTS is asbestos released by renovation or demolition of plant facilities. Asbestos emissions are controlled by a system of work practices. The amount of asbestos removed and disposed is reported to the Ohio EPA. No asbestos was removed or disposed in 1998.

\section{LIQUID DISCHARGES}

The quality of surface waters at DOE/PORTS is affected by wastewater discharges and groundwater transport of contaminants from land disposal of waste. Although bedrock characteristics differ somewhat among the watersheds of these surface waters, the observed differences in water chemistry are attributed to different contaminant loadings rather than geologic variation. Water quality, radioactivity, and flow measurements are made at a number of stations operated by DOE. Water samples are collected and analyzed at various intervals (weekly, monthly, etc.) for radiological and nonradiological parameters. 


\section{Radiological Liquid Discharges}

Virtually all radiological liquid discharges from DOE activities come from remediation activities. The locations of remediation activities are dispersed throughout DOE/PORTS. Radiologically contaminated liquid from remediation activities may be discharged from the groundwater treatment facilities. Trace concentrations of naturally occurring radiological constituents such as uranium may also be found in stormwater runoff.

\section{Radiological Liquid Sample Collection and Analytical Procedure}

All DOE outfalls are monitored by collecting samples. Samples are analyzed for total uranium concentrations, gross alpha, gross beta, and technetium $\left({ }^{99} \mathrm{Tc}\right)$-beta radioactivity. The ratio of alpha activity to total uranium is used with process data to calculate the proportions of the individual uranium isotopes.

\section{Radiological Liquid Monitoring Results}

Liquid radiological discharges from DOE/PORTS had no significant impact on public health or the environment. Uranium discharges from DOE/PORTS sources in 1998 totaled $1.86 \mathrm{~kg}$. A total of $0.0067 \mathrm{Ci}$ of radionuclides was discharged in 1998 from DOE/PORTS sources. No spills or accidental releases to surface water occurred in 1998.

\section{Radiological Monitoring Results for Surface Water from DOE Cylinder Storage Yards}

Ohio EPA requires monthly collection of surface water samples from the $\mathrm{X}-745 \mathrm{C}$ and $\mathrm{X}-745 \mathrm{E}$ depleted uranium hexafluoride cylinder storage yards. Samples are analyzed for alpha activity, beta activity, and total uranium. During 1998 alpha activity ranged from less than $3 \mathrm{pCi} / \mathrm{L}$ to $9 \mathrm{pCi} / \mathrm{L}$; beta activity ranged from less than $9 \mathrm{pCi} / \mathrm{L}$ to $74 \mathrm{pCi} / \mathrm{L}$; and total uranium ranged from $1.0 \mu \mathrm{g} / \mathrm{L}$ to $19.4 \mu \mathrm{g} / \mathrm{L}$. Surface water from this area is discharged through a USEC NPDES outfall.

\section{Nonradiological Liquid Discharges}

Nonradiological discharges are regulated by the NPDES permit. The permit was issued to DOE/PORTS on September 1, 1995 and modified on December 1, 1996, and May 1, 1997. DOE/PORTS has six discharge points, or outfalls, through which water is discharged from the site. Three outfalls discharge directly to surface water, and three discharge to the X-6619 Sewage Treatment Plant before leaving the site through USEC outfall 003 to the Scioto River. A brief description of each outfall for which DOE/PORTS is responsible follows, and the locations of the outfalls are shown in Fig. 4.1.

NPDES 012 (X-2230M holding pond, formerly Gas Centrifuge Enrichment Plant 001) - The X$2230 \mathrm{M}$ holding pond provides a quiescent zone for settling of suspended solids, dissipation of chlorine, and containment of oil with effluent baffling.

NPDES 013 (X-2230N holding pond, formerly Gas Centrifuge Enrichment Plant 002) - The X-2230N holding pond provides a quiescent zone for settling of suspended solids, dissipation of chlorine, and containment of oil with effluent baffling. A flow diagram of NPDES outfalls 012 and 013 is shown in Fig. 4.2 .

NPDES 015 (X-624 carbon filtration facility - formerly outfall 609) - This facility removes volatile organic compounds from contaminated groundwater originating from the X-701B plume interceptor trenches. These groundwater interceptor trenches were constructed to control the migration of volatile organic compound-contaminated groundwater toward Little Beaver Creek. A flow diagram for outfall 015 is shown in Fig. 4.3. 


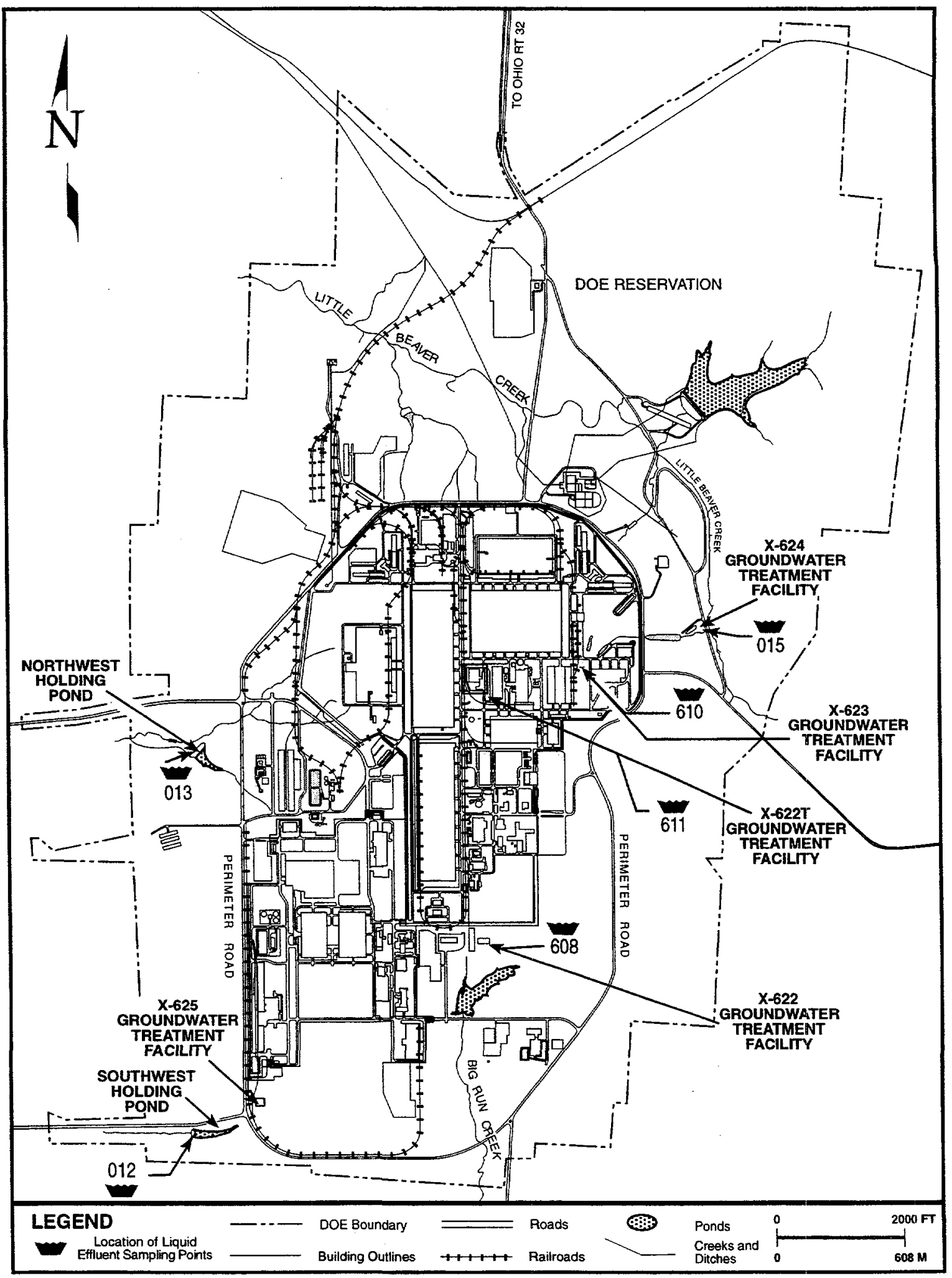

Fig. 4.1. NPDES water sampling locations and major wastewater sources and systems at DOEIPORTS 


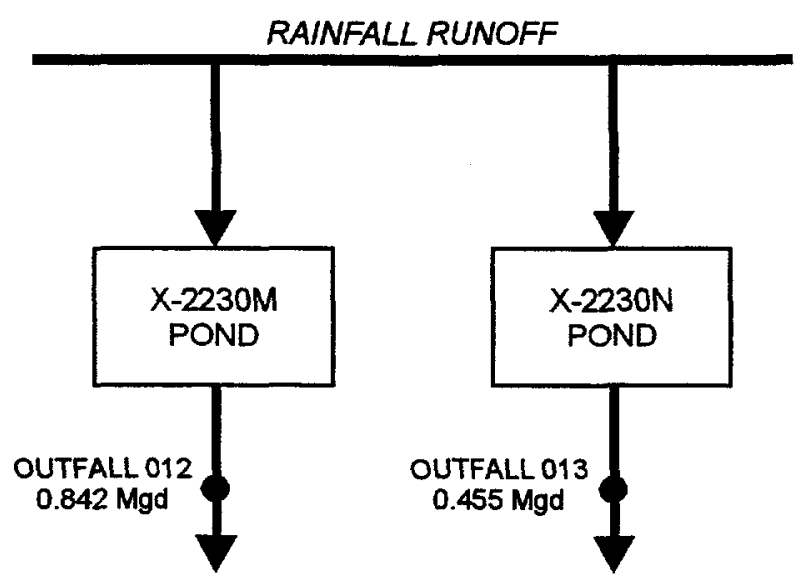

Fig. 4.2. Flow diagram for outfalls 012 and 013 (X-2230M holding pond and X-2230N holding pond).

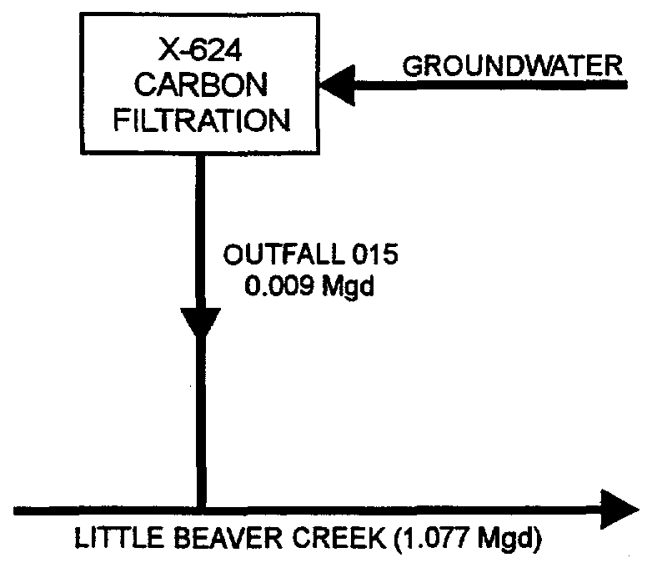

Fig. 4.3. Flow diagram for outfall 015 (X-624 carbon filtration facility).

NPDES 608 (X-622 groundwater treatment facility) - This facility removes volatile organic compounds from contaminated groundwater originating from X-231B, X-749, and Peter Kiewit Landfill site remediation activities. Treated water is discharged to the sanitary sewer and then to USEC outfall 003.

NPDES 610 (X-623 carbon filtration facility - formerly outfall 606) - This facility replaced the X$701 \mathrm{E}$ in June 1994 and removes volatile organic compounds from contaminated groundwater originating from site remediation activities and from miscellaneous well development and purge waters. Treated water is discharged to the sanitary sewer and then to USEC outfall 003.

NPDES 611 (X-622T groundwater treatment facility) - This facility removes volatile organic compounds from groundwater collecting in sumps located in the basements of the X-705 decontamination facility and the X-700 facility. Treated water is discharged to the sanitary sewer and then to USEC outfall 003.

\section{Nonradiological Liquid Sample Collection and Analytical Procedure}

Sampling of nonradioactive constituents is regulated under the DOE/PORTS NPDES permit. Analyses are performed in accordance with Title 40 Code of Federal Regulations Part 136.

\section{Nonradiological Liquid Monitoring Results}

The 1998 NPDES compliance rate for DOE outfalls was $100 \%$. Compliance rates for individual parameters were $100 \%$.

\section{Radiological and Nonradiological Groundwater Monitoring Results} Chapter 6.

Radiological and nonradiological results for groundwater monitoring at DOE/PORTS can be found in

\section{BIOLOGICAL MONITORING}

Archery deer hunting took place at PORTS from November 9, 1997 through January 17, 1998 and from October 3, 1998 through January 30, 1999. Forty-seven kidneys from deer harvested during the 19971998 season were analyzed for technetium-99 and total uranium. These results for these isotopes indicated 
that they were below background or below detection limits in each sample. A random sample of 12 kidneys from deer harvested during the 1998-1999 season were analyzed for americium-241, neptunium-237, plutonium-238, plutonium-239/240, technetium-99, and total uranium. These results for these isotopes indicated that they were below detection limits in all 12 samples. All deer harvested at PORTS were monitored for surface radiological contamination prior to release from the site. No contamination was detected. 


\title{
5. Dose
}

\begin{abstract}
Potential impacts on human health from DOE/PORTS operations are calculated based on environmental monitoring and surveillance data. The maximum potential committed effective dose equivalent that a person living off site could receive from airborne radiological releases from DOE activities at PORTS is $0.00025 \mathrm{mrem} /$ year. Based on driving past the DOE/PORTS depleted uranium cylinder storage yards to and from work, the maximum estimated potential exposure to the public from radiation from the cylinder yards is less than $0.5 \mathrm{mrem} / \mathrm{year}$. These potential doses are well below the $10 \mathrm{mrem} / \mathrm{year}$ limit set by the U.S. EPA, the $100 \mathrm{mrem} / \mathrm{year}$ limit set by DOE, and the $300 \mathrm{mrem} /$ year (approximate) dose that the average person in the United States receives from natural sources of radiation.
\end{abstract}

\section{INTRODUCTION}

Airborne releases of radionuclides from DOE facilities are regulated by the U.S. EPA under the Clean Air Act and the National Emission Standards for Hazardous Air Pollutants. These regulations set an annual dose limit of $10 \mathrm{mrem} /$ year to any member of the public as a result of airborne radiological releases, and also set performance standards for demonstrating compliance with the dose limit. Airborne radionuclide discharges are also regulated, along with all other atmospheric pollutants, under the Ohio Permit to Operate requirements.

DOE also regulates radionuclide emissions to all environmental media through DOE Orders 5400.1, General Environmental Protection Program, and 5400.5, Radiation Protection of the Public and the Environment. DOE Order 5400.5 sets an annual dose limit of $100 \mathrm{mrem} /$ year to any member of the public. The DOE limit includes all radionuclide releases from a facility, unlike the National Emission Standards for Hazardous Air Pollutants, which apply to only airborne radiological releases.

Airborne discharges of chemical agents are regulated under the Ohio Permit to Operate requirements issued under the state equivalent of the Clean Air Act. Enforceable limits on emissions listed in these permits are based on maintaining normal ambient air concentrations within ambient air quality standards (i.e., the limits are not directly enforceable on individual sources).

Liquid discharges are regulated by the NPDES permit issued under the Clean Water Act. Enforceable limits in the permit are based on maintaining water quality in receiving streams.

Small quantities of radionuclides were released to the environment from DOE/PORTS operations during 1998. This chapter summarizes estimates of the potential consequences of the releases and describes the methods used to make the estimates.

\section{RADIOLOGICAL DOSE CALCULATION}

Exposure to radioactive materials could occur from releases to the atmosphere, surface water, or groundwater. In addition, a dose could be received through direct external irradiation by radiation emanating from buildings and other objects located within PORTS boundaries. Doses are estimated for all potentially significant exposure pathways relevant to the exposure modes just described. Appendix A provides detailed information about radiation and radioactivity. 


\section{Terminology}

Most consequences associated with radionuclides released to the environment are caused by interactions between human tissue and various types of radiation emitted by the radionuclides. These interactions involve the transfer of energy from radiation to tissue, possibly resulting in tissue damage. Radiation may come from radionuclides outside the body (in or on environmental media or objects) or from radionuclides deposited inside the body (by inhalation, ingestion, and, in a few cases, absorption through the skin). Exposures to radiation from radionuclides outside the body are called external exposures; exposures to radiation from radionuclides inside the body are called internal exposures. This distinction is important because external exposure occurs only as long as a person is near the external radionuclide; simply leaving the area of the source will stop the exposure. Internal exposure continues as long as the radionuclide remains inside the body.

The three natural uranium isotopes $\left({ }^{234} \mathrm{U},{ }^{235} \mathrm{U}\right.$, and $\left.{ }^{238} \mathrm{U}\right)$ and technetium $\left({ }^{99} \mathrm{Tc}\right)$ are potentially significant when calculating the radiation dose received by the public around DOE/PORTS. Each of these radionuclides has a half-life that exceeds 200,000 years; consequently, the sampling frequency does not need to allow for radioactive decay. The types of radiation emitted vary from one radionuclide to the next. The predominance of beta and alpha emitters indicates the importance of internal exposures resulting from possible ingestion or inhalation of radionuclides.

A number of specialized units have been defined for characterizing exposures to ionizing radiation. Because the damage associated with such exposures results primarily from the deposition of radiant energy in tissue, the units are defined in terms of the amount of incident radiant energy absorbed by tissue and in terms of the biological consequences of the absorbed energy. These units include the following:

- Absorbed dose -- a physical quantity that defines the amount of incident radiant energy absorbed per unit mass of an irradiated material; its unit of measure is the rad. The absorbed dose depends on the type and energy of the incident radiation and on the atomic number of the absorbing material.

- Dose equivalent -- a quantity that expresses the biological effectiveness of an absorbed dose in a specified human organ or tissue; its unit of measure is the rem. The dose equivalent is numerically equal to the absorbed dose multiplied by modifying factors that relate the absorbed dose to biological effects. In this report, the term "dose equivalent" is often shortened to "dose."

- Effective dose equivalent -- a risk-equivalent dose equivalent that can be used to estimate health-effect risk to exposed persons; it is a weighted sum of dose equivalents to specified organs.

- Committed (effective) dose equivalent -- the total (effective) dose equivalent that will be received over a specified time period (in this document, calculations are based on a 50-year period) because of radionuclides taken into the body during the current year.

- Collective dose equivalent -- the sum of committed (effective) dose equivalents to all individuals in an exposed population. The unit of measure is the person-rem. The collective dose is also frequently called the "population dose."

- Dose conversion factor -- the dose equivalent received from exposure to a unit quantity of a radionuclide by a specific exposure pathway. Two types of dose conversion factors exist. One type gives the committed dose equivalent (rem) resulting from intake (by inhalation and ingestion) of a unit activity [1.0 $\mu \mathrm{Ci}(37 \mathrm{~Bq})]$ of a radionuclide. The second type gives the dose equivalent rate (mrem) per unit activity $[1.0 \mu \mathrm{Ci}(37 \mathrm{~Bq})]$ of a radionuclide in a unit $\left(\mathrm{cm}^{3}\right.$ or $\left.\mathrm{cm}^{2}\right)$ of an environmental compartment (air or ground surface). 
- Total effective dose equivalent -- the sum of the effective dose equivalent for external exposures and the committed (effective) dose equivalent for internal exposure.

\section{Dose Calculation for Airborne Radionuclides}

The effect of radionuclides released to the atmosphere by DOE/PORTS during 1998 was characterized by calculating effective dose equivalents to the maximally exposed person (a hypothetical individual who is assumed to reside at the most exposed point on the plant boundary) and to the entire population (approximately 918,000 residents) within 50 miles of the plant. Dose calculations were made using the Clean Air Assessment Package-88 of computer codes (Beres 1990), which was developed under sponsorship of the U.S. EPA for use in demonstrating compliance with the National Emission Standards for Hazardous Air Pollutants for radionuclides. This package contains the most recently approved version of the AIRDOC-EPA and DARTAB computer codes and the ALLRAD88 radionuclide data file. The AIRDOS-EPA computer code implements a steady-state Gaussian plume atmospheric dispersion model to calculate concentrations of radionuclides in the air and on the ground. It uses Nuclear Regulatory Commission Regulatory Guide 1.109 food-chain models to calculate radionuclide concentrations in foodstuffs (e.g., vegetables, meat, and milk) and subsequent intakes by individuals. The concentrations and human intakes are used by the U.S. EPA's latest version of the DARTAB computer code to calculate effective dose equivalents to humans from radionuclides released to the atmosphere. The dose calculations use the dose conversion factors contained in the ALLRAD88 data file.

Radionuclide release data were modeled for two DOE/PORTS permitted sources: the X-326 glovebox and the X-744G glovebox. Meteorological data used in the calculations consisted of joint frequency distributions of wind direction, wind speed, and atmospheric stability that were prepared from data collected during 1998 at the $30 \mathrm{~m}$ station on the USEC meteorological tower. Rainfall during 1998 was $117.1 \mathrm{~cm}$ (46.1 in), the average air temperature was $13.0^{\circ} \mathrm{C}\left(55.4^{\circ} \mathrm{F}\right)$, and the average mixing layer height was $1,000 \mathrm{~m}$.

The dose calculations assumed that each person remained unprotected, resided at home (actually outside the house) during the entire year, and obtained food according to the rural pattern defined in the National Emission Standards for Hazardous Air Pollutants background documents (U.S. EPA 1989). This pattern specifies that $70 \%$ of the vegetables and produce, $44.2 \%$ of the meat, and $39.9 \%$ of the milk consumed by each person are produced in the local area (e.g., in a home garden). The remaining portion of each food is assumed to be produced within 50 miles of DOE/PORTS. For collective effective dose equivalent estimates, production of beef, milk, and crops within 50 miles of DOE/PORTS was calculated using the state-specific production rates provided with the Clean Air Act Assessment Package- 88.

\section{Airborne Radionuclide Dose Calculation Results}

The maximum potential effective dose equivalent to an off-site individual from 1998 radiological releases from DOE/PORTS was $0.00025 \mathrm{mrem} /$ year, which is well below the 10 -mrem/year National Emission Standards for Hazardous Air Pollutants limit applicable to DOE/PORTS and the approximate 300mrem dose/year that the average individual in the United States receives from natural sources of radiation.

The collective effective dose equivalent to the entire population around DOE/PORTS in 1998 was 0.23 person-rem, which is based on the maximum individual effective dose equivalent and the number of residents within 50 miles of DOE/PORTS. The collective effective dose equivalent to the nearest community, Piketon, was calculated to be 0.00001 person-rem. 


\section{Dose Calculation for Waterborne Radionuclides}

Water is sampled at all plant outfalls and in the receiving streams. DOE/PORTS sources discharged $1.86 \mathrm{~kg}$ of uranium and $0.0067 \mathrm{Ci}$ of radionuclides in 1998. DOE/PORTS discharges remained well below the DOE standard, and below the limits set by the Occupational Safety and Health Administration, the Nuclear Regulatory Commission, and the International Committee of Radiation Protection.

\section{Radiological Dose Results for DOE/PORTS Workers and Visitors}

The Radiation Exposure Information Reporting System report is an electronic file created annually to comply with DOE Order 5484.1. This report contains exposure results for all monitored individuals at DOE/PORTS, including visitors, with a positive exposure during the previous calendar year. The 1998 Radiation Exposure Information Reporting System report indicated that there were no visitors with a positive exposure.

The average total effective dose in 1998 for all DOE/PORTS employees and subcontractors was 0.95 mrem.

\section{Radiological Dose Results from DOE/PORTS Facilities}

The DOE/PORTS Radiological Protection Organization monitors radiation levels in active DOE/PORTS facilities on a continual basis. This radiation monitoring assists in determining the radiation levels that workers are exposed to and in identifying changes in radiation levels. These measurements provide 1) information for worker protection, 2) a means to trend radiological exposure data for specified facilities, and 3) a means to estimate potential public exposure to radiation from DOE/PORTS activities.

Thermoluminescent dosimeters (TLDs) are used to measure beta, gamma, and neutron radiation. The TLD consists of four crystals that store radiation as potential energy. When the TLD crystals are heated, this stored energy is released as light. This light is quantifiable and correlates directly to the amount of ionizing radiation to which the TLD was exposed. The TLD can differentiate exposure to beta, gamma, and neutron radiation as well as shallow and deep radiation. Shallow radiation penetrates only the outer portion of the skin. Deep radiation penetrates the entire body (similar to an x-ray).

Five major DOE/PORTS facilities are monitored for ionizing radiation exposure levels: the X-7725 waste storage facility, X-326 storage facility, X-345 storage facility, X-744G storage facility, and depleted uranium cylinder storage yards $[\mathrm{X}-745 \mathrm{C}(1), \mathrm{X}-745 \mathrm{C}(2)$, and $\mathrm{X}-745 \mathrm{E}]$.

None of these facilities are readily accessible to the public; however, Perimeter Road passes close to the edge of the cylinder yards. Therefore, data from radiation monitoring at the cylinder yards are used to assess potential exposure to the public from passing traffic on Perimeter Road.

The radiological exposure data provided from the TLDs at each facility are based on exposure to ionizing radiation for an entire year (i.e., 24 hours/day, 7 days/week, 52 weeks/year - 8,736 hours/year). The radiological exposure to members of the general public is estimated as the time that a person drives on Perimeter Road past the cylinder yards. Public traffic is not allowed to stop in this area, and past tests provide the estimate that a car traveling slightly under the posted speed limit passes by the cylinder yards in 20 to 30 seconds. Potential public exposure to radiation from the cylinder yards is calculated as follows:

\section{Assumptions:}

- A person driving to and from work (2 exposures/day) is the most conservative plausible scenario.

- The driver will pass by the cylinder yards within 1 minute.

\section{5-4 Dose}




\section{Calculation:}

1. Add the deep and shallow dose rates to get a combined dose for the year.

2. Subtract natural background radiation $-78 \mathrm{mrem} /$ year. Natural background radiation consists of 50 $\mathrm{mrem} /$ year cosmic radiation and $28 \mathrm{mrem} /$ year terrestrial radiation (see Appendix A).

3. Divide this dose measurement by 8736 hours to determine the exposure per hour.

4. Multiple this exposure by 8.7 hours/year ( 1 minute/trip x 2 trips/day x 5 work-days/week x 52 weeks/year).

The average deep dose and shallow dose reported in Table 5.1 represent the gross exposure levels at each facility. These levels include ionizing radiation from PORTS activities in those areas and natural background radiation (i.e., terrestrial and cosmic radiation). The final column provides the potential dose to the public from each area.

Table 5.1. Radiation doses at DOE/PORTS facilities -1998 .

\begin{tabular}{|l|c|c|c|}
\hline \multicolumn{1}{|c|}{ Facility } & $\begin{array}{c}\text { Average Deep Dose } \\
\text { (mrem/year) continuous } \\
\text { exposure (8736 hours) }\end{array}$ & $\begin{array}{c}\text { Average } \\
\text { Shallow Dose } \\
\text { (mrem/year) continuous } \\
\text { exposure (8736 hours) }\end{array}$ & $\begin{array}{c}\text { Estimated Public Dose } \\
\text { (mrem/year) 8.7 hours } \\
\text { exposure }\end{array}$ \\
\hline $\mathrm{X}-7725$ & 90 & 157 & NA $^{\mathrm{a}}$ \\
\hline $\mathrm{X}-326$ & 9 & 18 & $\mathrm{NA}^{\mathrm{a}}$ \\
\hline $\mathrm{X}-345$ & 83 & 114 & $\mathrm{NA}^{\mathrm{a}}$ \\
\hline $\mathrm{X}-745 \mathrm{C}(1)$ & & & 0.12 \\
\hline $\mathrm{X}-745 \mathrm{C}(2)$ & 85 & 110 & 0.24 \\
\hline $\mathrm{X}-745 \mathrm{E}$ & 152 & 171 & 0.10 \\
\hline
\end{tabular}

${ }^{a}$ Not applicable -no public exposure to radiation from these buildings.

Using the assumptions and calculations provided above, exposure to the public from radiation from the cylinder yards is less than $0.5 \mathrm{mrem} /$ year. The average yearly dose to a person in the United States from natural and man-made radiation sources is approximately $366 \mathrm{mrem}$ (see Appendix A). The potential estimated dose from the cylinder yards to a member of the public is less than 0.2 percent of the average yearly radiation exposure for a person in the United States.

\section{CALCULATION OF DIRECT EXPOSURE TO CHEMICALS}

Direct exposure to chemicals from DOE/PORTS does not represent a likely pathway of exposure for the public. For airborne releases, concentrations off site are too small to present problems through dermal exposure or inhalation pathways. Water discharge outfalls are located within areas of the site that are not readily accessible to the general public. Public exposure to water from the outfalls on a daily basis is highly unlikely, and ingestion of water directly from the outfalls is even less likely. 


\title{
6. Groundwater
}

\begin{abstract}
The purpose of groundwater monitoring at DOE/PORTS is to characterize the hydrogeology and monitor groundwater quality at the plant and its environs. More than 400 monitoring wells are used to track the flow of groundwater and to measure any contaminants present both on and off site. Groundwater monitoring extends to surface water that receives direct input from groundwater sources. Off-site sampling is conducted to assess the effects of PORTS operations on nearby water supplies.
\end{abstract}

\section{INTRODUCTION}

Groundwater monitoring at DOE/PORTS includes RCRA hazardous waste units, solid waste disposal units, RCRA Corrective Action units, special investigations, and surveillance monitoring. Special investigations that include groundwater monitoring are discussed in Chapter 3, Environmental Programs. The U.S. Department of Energy Portsmouth Annual Environmental Report for 1995 provides detailed information on the following characteristics of DOE/PORTS:

- groundwater hydrology,

- geological and hydrogeological setting,

- topography,

- stratigraphy,

- geologic history, and

- groundwater hydrogeology.

The 1998 RCRA Annual Hazardous Waste Report, Groundwater Monitoring Section, provides further details on the groundwater plumes at DOE/PORTS, specific monitoring well identifications, and analytical results for monitoring wells.

\section{USES OF GROUNDWATER IN THE VICINITY}

Groundwater is used as a domestic, municipal, and industrial water supply in the vicinity of DOE/ PORTS. Most municipal and industrial water supplies in Pike County are developed from the Scioto River Valley buried aquifer. Groundwater in the Berea sandstone and Gallia sand formations that underlie PORTS is not used as domestic, municipal, or industrial water supplies. Domestic water supplies are obtained from either unconsolidated deposits in preglacial valleys, major tributaries to the Scioto River Valley, or from fractured bedrock encountered during drilling.

The PORTS reservation is the largest industrial user of water in the vicinity and obtains its water from the X-608, X-605G, and X-6609 water supply well fields, which are next to the Scioto River south of Piketon. The wells tap the Scioto River Valley buried aquifer. Total groundwater production averages 13 million gal/ day for the entire site, including USEC activities.

Contaminants in the groundwater beneath DOE/PORTS do not affect the quality of the water in the Scioto River Valley buried aquifer. 


\section{APPLICABLE MONITORING STANDARDS}

Groundwater monitoring at DOE/PORTS is required under three RCRA programs: closure requirements for hazardous waste units, closure requirements for solid waste disposal units, and RCRA Corrective Action. DOE/PORTS is located within the jurisdiction of the Ohio EPA Southeast District Office in Logan, Ohio. The Ohio EPA has primary enforcement authority for RCRA requirements within Ohio. U.S. EPA Region V also has oversight authority for the RCRA Corrective Action Program.

Groundwater monitoring regulations under closure requirements for both hazardous waste and solid waste units require PORTS to (1) monitor for detection of contaminants in groundwater; (2) prepare a groundwater quality assessment plan if contaminants are discovered; and (3) monitor to assess the extent of contamination, as required by the groundwater quality assessment plan. Groundwater monitoring requirements also continue after a unit, such as a landfill, is closed. Ohio Administrative Code 3745-66 contains the groundwater monitoring regulations applicable to hazardous waste units at PORTS. Ohio Administrative Codes 3745-27-10 and 3745-29-10 require groundwater monitoring for releases at solid waste disposal sites.

Requirements for groundwater monitoring under the RCRA Corrective Action Program at PORTS are determined on a site-specific basis through the RCRA Corrective Action process. Further information on the RCRA Corrective Action process is provided in Chapter 3 and in the discussions of specific RCRA Corrective Action units.

\section{GROUNDWATER MONITORING AT DOE/PORTS}

Groundwater monitoring is performed at six RCRA hazardous waste units (Figure 6.1) and three solid waste units (Figure 6.2) at PORTS. Parameters that are monitored at each unit are approved by Ohio EPA and are listed in Table 6.1. Two RCRA Corrective Action Program units, the X-611A Lime Sludge Lagoons and the X-749B Peter Kiewit Landfill, also require routine groundwater monitoring. Parameters monitored at these units are discussed in the section for the unit. In 1998, wells were sampled with dedicated bladder pumps, and low-flow sampling techniques were used, where possible, to minimize turbidity.

Under the regulations for both hazardous and solid waste, different types of groundwater monitoring are conducted, based on the conditions present at each unit. Detection monitoring is performed at units where there has been no significant change of groundwater indicator parameters for upgradient and downgradient wells. Detection monitoring uses statistical comparison of monitoring parameters at upgradient and downgradient wells to determine whether a release from the unit has affected groundwater. If a release from the unit is identified, the groundwater contaminant plume associated with the unit is characterized during a groundwater quality assessment, and assessment monitoring is performed according to a groundwater quality assessment plan.

Assessment monitoring is conducted to characterize the extent, rate of migration, and concentration of hazardous and solid waste constituents in groundwater. In general, PORTS compares constituents detected in the groundwater at units in the assessment monitoring program to preliminary remediation goals to assess the potential for the concentrations of each constituent to affect human health and the environment. These preliminary remediation goals have been determined as part of the RCRA Corrective Action process. Preliminary remediation goals are based on naturally occurring concentrations of some constituents, on riskbased numbers calculated by the EPA, such as maximum contaminant levels for drinking water, or are determined through a site-specific risk assessment.

Detection monitoring is being performed at four units: (1) the X-701C neutralization pit, (2) the X735 RCRA landfill (northern portion), (3) the X-735 industrial solid waste landfill (southern portion), and (4) the X-749A classified materials disposal facility. Assessment monitoring is being performed at four units:

(1) the X-231B southwest oil biodegradation plot, (2) the X-616 chromium sludge surface impoundments,

(3) the X-701B holding pond, and (4) the X-749 north and south contaminated materials storage yard.

\section{6-2 Groundwater}




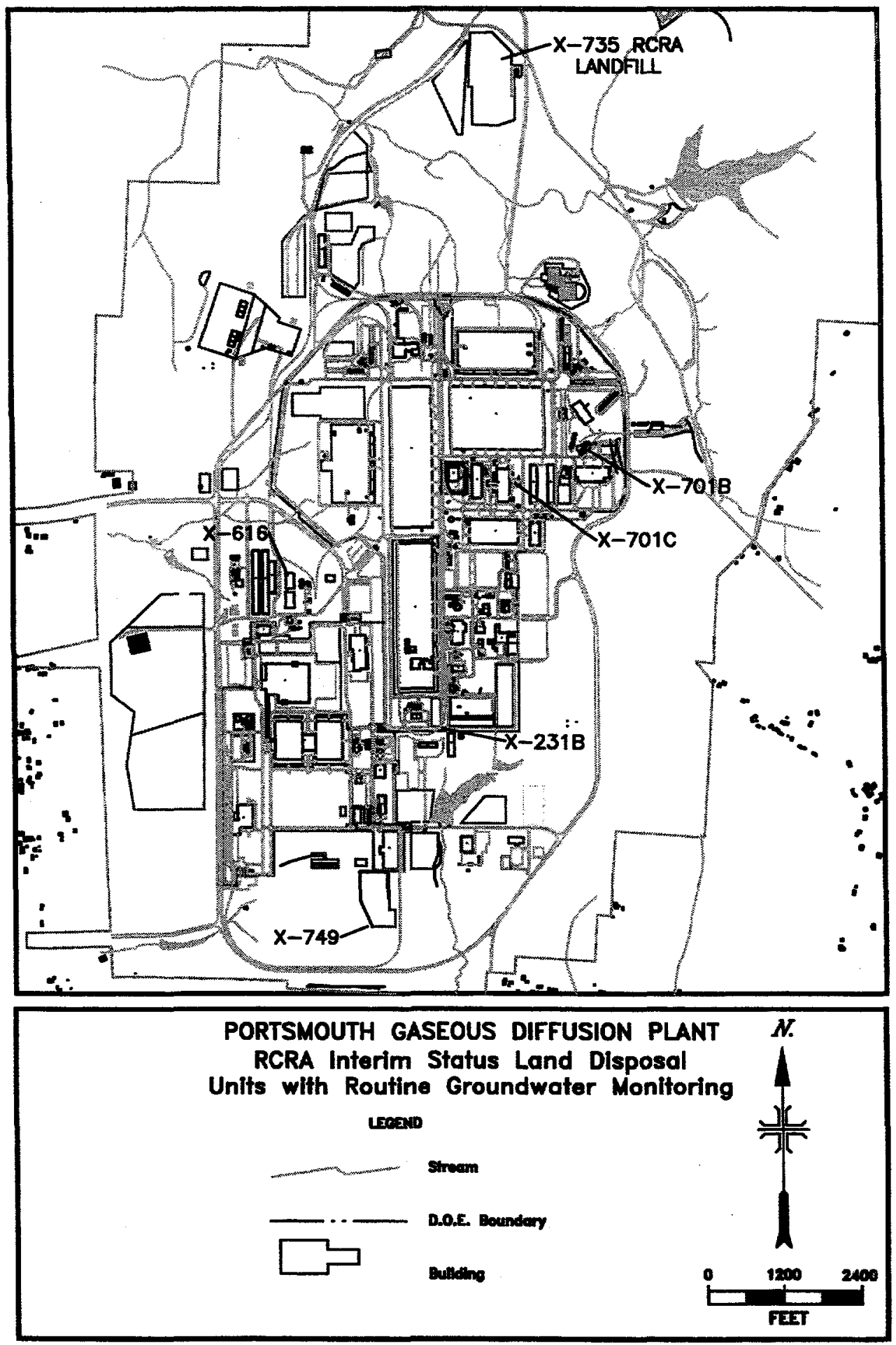

Fig. 6.1. RCRA hazardous waste units at DOE/PORTS. 
Table 6.1. Analyte analysis required for monitoring at RCRA hazardous waste units, solid waste units, corrective action units ${ }^{\mathrm{a}}$, surface water locations, and off-site locations at DOE/PORTS.

\begin{tabular}{|c|c|c|c|c|c|c|c|c|c|c|}
\hline \multirow[b]{2}{*}{ Analyte } & \multicolumn{10}{|c|}{ Monitoring Location } \\
\hline & $\begin{array}{c}\text { PK } \\
\text { Landfill } \\
\end{array}$ & $\mathrm{X}-701 \mathrm{~B}^{\mathrm{c}}$ & $\mathrm{X}-749^{\text {c,d }}$ & $\mathrm{X}-231 \mathrm{~B}^{c}$ & $X-616^{c}$ & $X-735^{\text {c,d }}$ & $\begin{array}{c}\begin{array}{c}\text { Surface } \\
\text { Water }\end{array} \\
\end{array}$ & Off-Site & $\mathrm{X}-701 \mathrm{C}^{\mathrm{c}}$ & $\mathrm{X}-749 \mathrm{~A}^{\mathrm{d}}$ \\
\hline & \multicolumn{10}{|c|}{$\begin{array}{l}\text { Volatile organic compounds } \\
\text { (Method } 8260)\end{array}$} \\
\hline Acetone & $\checkmark$ & $\checkmark$ & $\checkmark$ & $\checkmark$ & $\checkmark$ & $\checkmark$ & $\checkmark$ & $\checkmark$ & $\checkmark$ & $\checkmark$ \\
\hline Benzene & $\checkmark$ & $\checkmark$ & $\checkmark$ & $\checkmark$ & $\checkmark$ & $\checkmark$ & $\checkmark$ & $\checkmark$ & $\checkmark$ & $\checkmark$ \\
\hline Bromodichloromethane & $\checkmark$ & $\checkmark$ & $\checkmark$ & $\checkmark$ & $\checkmark$ & $\checkmark$ & $\checkmark$ & $\checkmark$ & $\checkmark$ & $\checkmark$ \\
\hline Bromoform & $\checkmark$ & $\checkmark$ & $\checkmark$ & $\checkmark$ & $\checkmark$ & $\checkmark$ & $\checkmark$ & $\checkmark$ & $\checkmark$ & $\checkmark$ \\
\hline Bromomethane & $\checkmark$ & $\checkmark$ & $\checkmark$ & $\checkmark$ & $\checkmark$ & $\checkmark$ & $\checkmark$ & $\checkmark$ & $\checkmark$ & $\checkmark$ \\
\hline 2-butanone & $\checkmark$ & $\checkmark$ & $\checkmark$ & $\checkmark$ & $\checkmark$ & $\checkmark$ & $\checkmark$ & $\checkmark$ & $\checkmark$ & $\checkmark$ \\
\hline Carbon disulfide & $\checkmark$ & $\checkmark$ & $\checkmark$ & $\checkmark$ & $\checkmark$ & $\checkmark$ & $\checkmark$ & $\checkmark$ & $\checkmark$ & $\checkmark$ \\
\hline Carbon tetrachloride & $\checkmark$ & $\checkmark$ & $\checkmark$ & $\checkmark$ & $\checkmark$ & $\checkmark$ & $\checkmark$ & $\checkmark$ & $\checkmark$ & $\checkmark$ \\
\hline Chlorobenzene & $\checkmark$ & $\checkmark$ & $\checkmark$ & $\checkmark$ & $\checkmark$ & $\checkmark$ & $\checkmark$ & $\checkmark$ & $\checkmark$ & $\checkmark$ \\
\hline Chlorodibromomethane & $\checkmark$ & $\checkmark$ & $\checkmark$ & $\checkmark$ & $\checkmark$ & $\checkmark$ & $\checkmark$ & $\checkmark$ & $\checkmark$ & $\checkmark$ \\
\hline Chloroethane & $\checkmark$ & $\checkmark$ & $\checkmark$ & $\checkmark$ & $\checkmark$ & $\checkmark$ & $\checkmark$ & $r$ & $\checkmark$ & $\checkmark$ \\
\hline Chloroform & $\checkmark$ & $\checkmark$ & $\checkmark$ & $\checkmark$ & $\checkmark$ & $\checkmark$ & $\checkmark$ & $\checkmark$ & $\checkmark$ & $\checkmark$ \\
\hline Dichlorobenzenes & $\checkmark$ & $\checkmark$ & $\checkmark$ & $\checkmark$ & $\checkmark$ & $\checkmark$ & $\checkmark$ & $\checkmark$ & $\checkmark$ & $\checkmark$ \\
\hline 1,1-dichloroethane & $\checkmark$ & $\checkmark$ & e & $\checkmark$ & $\checkmark$ & $\checkmark$ & $\checkmark$ & $\checkmark$ & $\checkmark$ & $\checkmark$ \\
\hline 1,2-dichloroethane & $\checkmark$ & $\checkmark$ & e & $\checkmark$ & $\checkmark$ & $\checkmark$ & $\checkmark$ & $\checkmark$ & $\checkmark$ & $\checkmark$ \\
\hline 1,1-dichloroethene & $\checkmark$ & $\checkmark$ & e & $\checkmark$ & $\checkmark$ & $\checkmark$ & $\checkmark$ & $\checkmark$ & $\checkmark$ & $\checkmark$ \\
\hline 1,2-dichloroethene (cis/trans) & $\checkmark$ & $\checkmark$ & e & $\checkmark$ & $\checkmark$ & $\checkmark$ & $\checkmark$ & $\checkmark$ & $\checkmark$ & $\checkmark$ \\
\hline Ethyl benzene & $\checkmark$ & $\checkmark$ & $\checkmark$ & $\checkmark$ & $\checkmark$ & $\checkmark$ & $\checkmark$ & $\checkmark$ & $\checkmark$ & $\checkmark$ \\
\hline Freon-113 & $\checkmark$ & $\checkmark$ & e & $\checkmark$ & $\checkmark$ & $\checkmark$ & $\checkmark$ & $\checkmark$ & $\checkmark$ & $\checkmark$ \\
\hline Freon-114 & $\checkmark$ & $\checkmark$ & $\checkmark$ & $\checkmark$ & $\checkmark$ & $\checkmark$ & $\checkmark$ & $\checkmark$ & $\checkmark$ & $\checkmark$ \\
\hline 4-methyl-2-pentanone & $\checkmark$ & $\checkmark$ & $\checkmark$ & $\checkmark$ & $\checkmark$ & $\checkmark$ & $\checkmark$ & $\checkmark$ & $\checkmark$ & $\checkmark$ \\
\hline 1,1,2,2-tetrachloroethane & $\checkmark$ & $\checkmark$ & $\checkmark$ & $\checkmark$ & $\checkmark$ & $\checkmark$ & $\checkmark$ & $\checkmark$ & $\checkmark$ & $\checkmark$ \\
\hline Tetrachloroethene & $\checkmark$ & $\checkmark$ & $\checkmark$ & $\checkmark$ & $\checkmark$ & $\checkmark$ & $\checkmark$ & 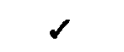 & $\checkmark$ & $\checkmark$ \\
\hline Toluene & $\checkmark$ & $\checkmark$ & $\checkmark$ & $\checkmark$ & $\checkmark$ & $\checkmark$ & $\checkmark$ & $\checkmark$ & $\checkmark$ & $\checkmark$ \\
\hline 1,1,1-trichloroethane & $\checkmark$ & $\checkmark$ & e & $\checkmark$ & $\checkmark$ & $\checkmark$ & $\checkmark$ & $\checkmark$ & 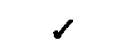 & $\checkmark$ \\
\hline 1,1,2-trichloroethane & $\checkmark$ & $\checkmark$ & $\checkmark$ & $\checkmark$ & $\checkmark$ & $\checkmark$ & $\checkmark$ & $\checkmark$ & $\checkmark$ & $\checkmark$ \\
\hline Trichloroethene & e & e & e & e & $\mathbf{e}$ & e & e & e & e & $\mathrm{e}$ \\
\hline Trichlorofluoromethane & $\checkmark$ & $\checkmark$ & $\checkmark$ & $\checkmark$ & $\checkmark$ & $\checkmark$ & $\checkmark$ & $\checkmark$ & $\checkmark$ & $\checkmark$ \\
\hline Vinyl chloride & $\checkmark$ & $\checkmark$ & $\checkmark$ & $\checkmark$ & $\checkmark$ & $\checkmark$ & $\checkmark$ & $\checkmark$ & $\checkmark$ & $\checkmark$ \\
\hline \multirow[t]{2}{*}{ Xylenes } & $\checkmark$ & $\checkmark$ & $\checkmark$ & $\checkmark$ & $\checkmark$ & $\checkmark$ & $\checkmark$ & $\checkmark$ & $\checkmark$ & $\checkmark$ \\
\hline & \multicolumn{10}{|c|}{ Radionuclide parameters } \\
\hline Gross alpha & $\checkmark$ & $\checkmark$ & $\checkmark$ & $\checkmark$ & $\checkmark$ & $\checkmark$ & $\checkmark$ & $\checkmark$ & $\checkmark$ & $\checkmark$ \\
\hline Gross beta & $\checkmark$ & $\checkmark$ & $\checkmark$ & $\checkmark$ & $\checkmark$ & $\checkmark$ & $\checkmark$ & $\checkmark$ & $\checkmark$ & $\checkmark$ \\
\hline Total uranium & $\checkmark$ & $\checkmark$ & $\checkmark$ & $\checkmark$ & $\checkmark$ & $\checkmark$ & $\checkmark$ & $\checkmark$ & $\checkmark$ & $\checkmark$ \\
\hline Technetium beta & $\checkmark$ & $\checkmark$ & $\checkmark$ & $\checkmark$ & $\checkmark$ & $\checkmark$ & $\checkmark$ & $\checkmark$ & $\checkmark$ & $\checkmark$ \\
\hline Transuranics ${ }^{r}$ & & $\checkmark$ & $\checkmark$ & $\checkmark$ & & & & & & \\
\hline Isotopic uranium & & $\checkmark$ & $\checkmark$ & $\checkmark$ & & $\checkmark$ & $\checkmark$ & & & \\
\hline
\end{tabular}


Table 6.1. Analyte analysis required for groundwater monitoring at RCRA hazardous waste units, solid waste units, corrective action units ${ }^{\mathfrak{a}}$, surface water locations, and off-site locations at DOE/PORTS (continued).

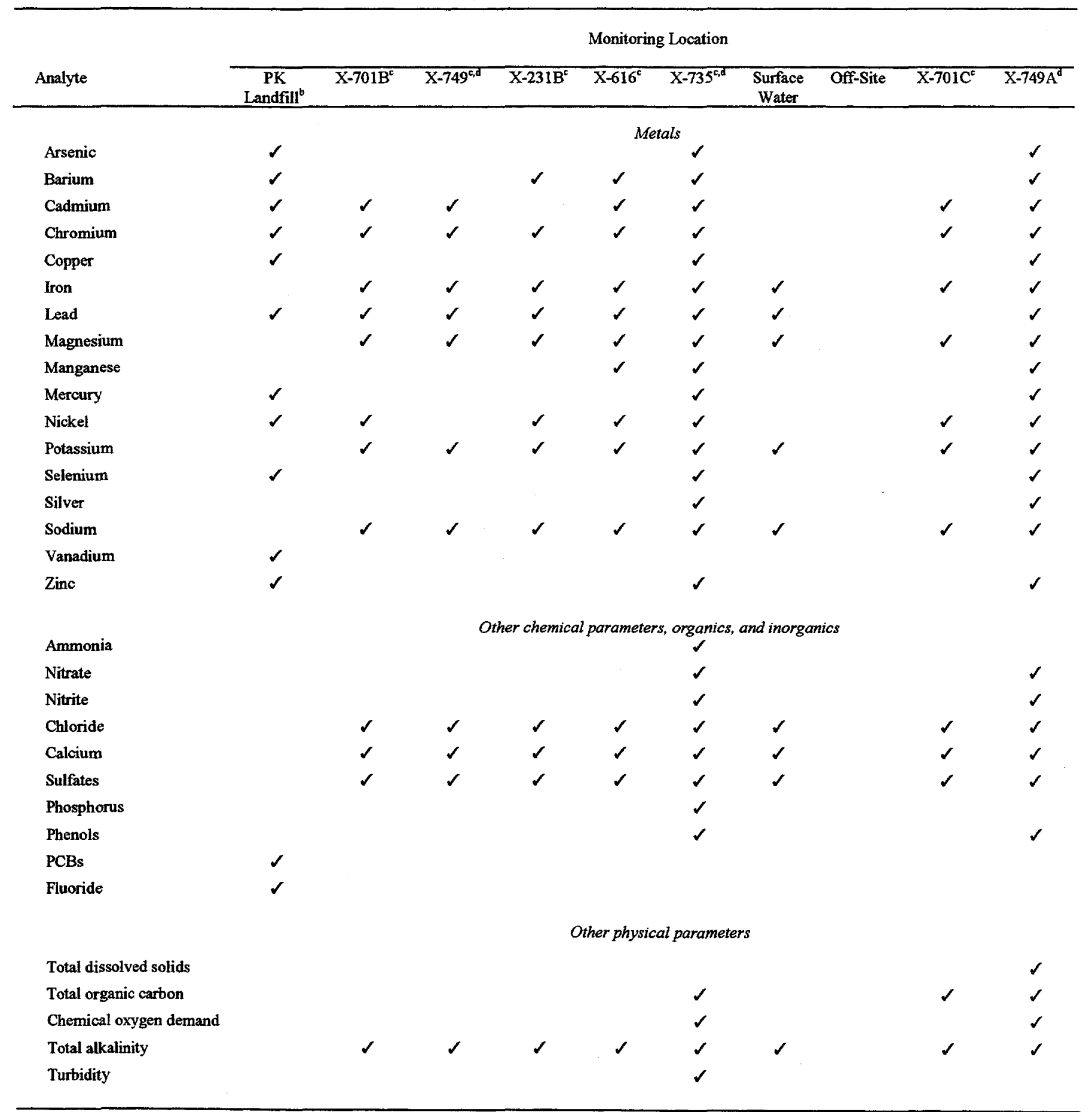

Parameters for the X-611A Lime Sludge Lagoons are listed in the section for that unit.

RCRA corrective action unit.

RCRA hazardous waste unit.

Solid waste landfill.

Primary volatile organic compounds of concern.

Only selected locations within the unit are sampled and analyzed for transuranics. 


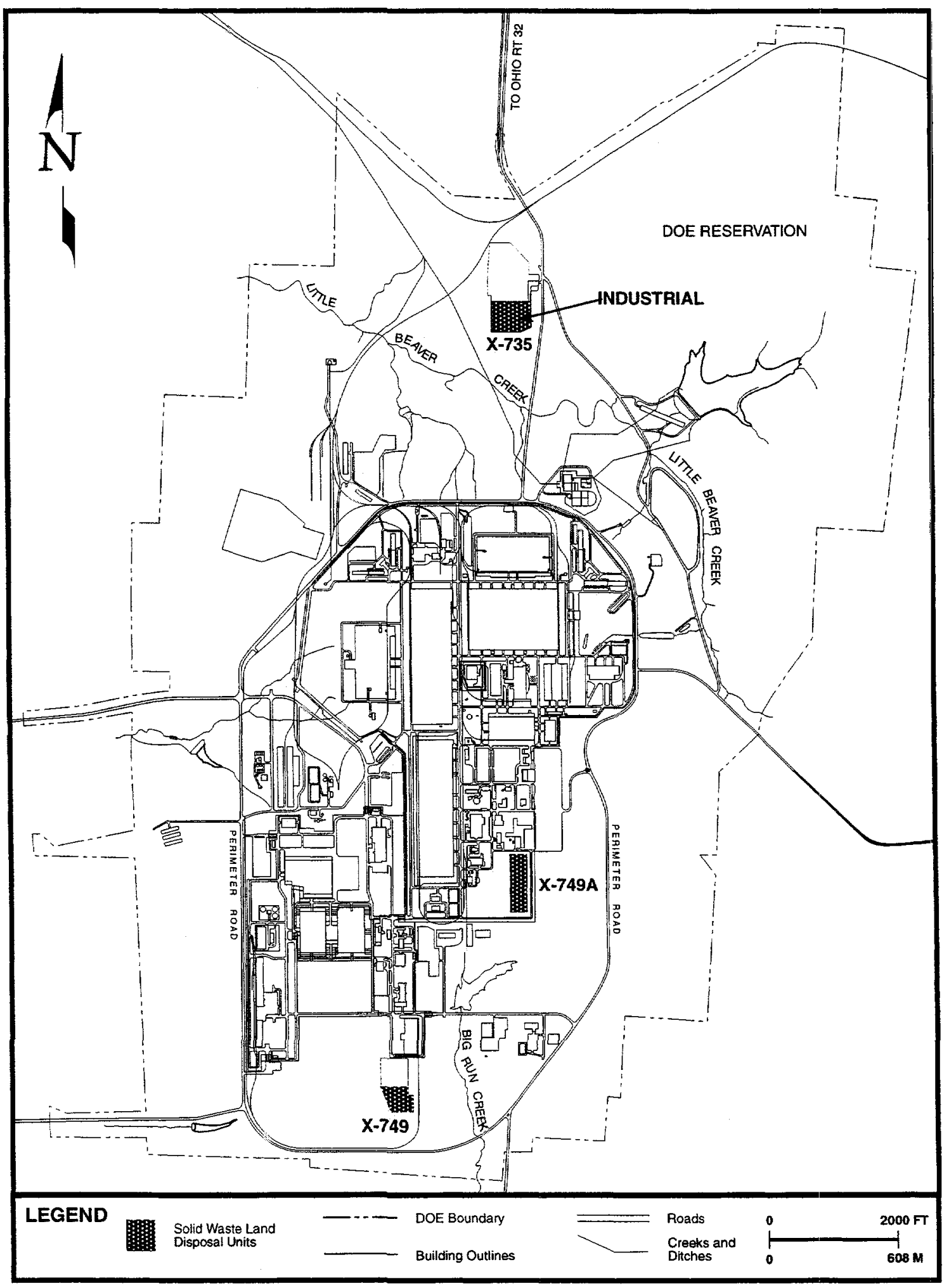

Fig. 6.2. Solid waste land disposal units at DOE/PORTS. 
Routine groundwater monitoring is also required under the RCRA Corrective Action Program Corrective Measures Implementation for the X-749B Peter Kiewit Landfill and the X-611A Lime Sludge Lagoons.

The surveillance monitoring program at DOE/PORTS consists of perimeter exit pathway monitoring, off-site sampling, water supply sampling, and baseline monitoring. Perimeter exit pathway monitoring assesses the effect of DOE/PORTS on regional groundwater quality and quantity. The off-site sampling and DOE/PORTS water supply sampling provide information to document any effect of DOE/PORTS operations on nearby residential water supplies and the PORTS water supply. Baseline monitoring is conducted to establish background data for use in assessing the effect of DOE/PORTS operations on the groundwater.

\section{SOLID WASTE UNITS}

\section{X-735 Industrial Solid Waste Landfill}

The X-735 industrial solid waste landfill was licensed by the state of Ohio for the disposal of industrial solid waste generated by activities at DOE/PORTS. Initially, a total of 17.9 acres was approved for disposal by the Ohio EPA and the Pike County Health Department; however, an investigation conducted by DOE/PORTS indicated that wipe rags contaminated with solvents had inadvertently been disposed in cells one through six. Therefore, the northern portion of the landfill was closed as a RCRA hazardous waste landfill and is referenced in the "RCRA Hazardous Waste Units" section of this chapter. The remaining three cells, A through C, continued to be regulated by the solid waste regulations and operated until December 31, 1997. The Director's Findings and Orders issued to DOE/PORTS on January 30, 1997, required closure of the facility to be completed in 1998. A landfill cap was installed in 1998 to complete closure of the unit.

In the southern area of X-735, groundwater flows toward the southwest. The calculated hydraulic conductivity in the Gallia sand ranges from a high of $1,440 \mathrm{ft} /$ day to a low of $4.3 \mathrm{ft} /$ day. The groundwater flow velocity, based on the arithmetic mean hydraulic conductivity value of $430 \mathrm{ft} /$ day, ranges from $1.7 \mathrm{ft} /$ day to $3.4 \mathrm{ft} /$ day.

Thirteen groundwater monitoring wells were installed around the entire facility, including both the RCRA hazardous waste and the industrial solid waste landfill. Five of the wells, surrounding the southern part of the facility, are used for semiannual detection monitoring for the industrial solid waste landfill (Fig. 6.3).

Statistical analysis of analytical results from the second semester of 1996 indicated that sulfate was present in one downgradient well at a concentration higher than concentrations in upgradient wells and at a concentration determined to be statistically significant. The assessment sampling program completed in 1997, however, determined that the sulfate concentration in the downgradient well resulted from natural variability and not from the release of leachate to groundwater. Ohio EPA agreed with this determination and approved the return to detection monitoring at the X-735 Industrial Solid Waste Landfill in 1998.

Analytical results from the two 1998 sampling events at the X-735 Industrial Solid Waste Landfill and the associated statistical analyses indicate that no release of leachate to the groundwater has occurred from this unit.

\section{X-749A Classified Materials Disposal Facility}

The 6-acre X-749A classified materials disposal facility operated from 1953 through 1988 for the disposal of wastes classified under the Atomic Energy Act. Potential contaminants include polychlorinated biphenyls, asbestos, radionuclides, and industrial waste. Closure of the unit, completed in 1994, included the construction of a multilayer cap and the installation of a drainage system to collect surface water runoff. The drainage system discharges via a USEC NPDES-permitted outfall.

Groundwater at the site generally flows to the southeast toward Big Run Creek, and the calibrated hydraulic conductivity for the Minford and Gallia sand in the vicinity of the unit is $0.73 \mathrm{ft} /$ day and $34 \mathrm{ft} /$ day, 


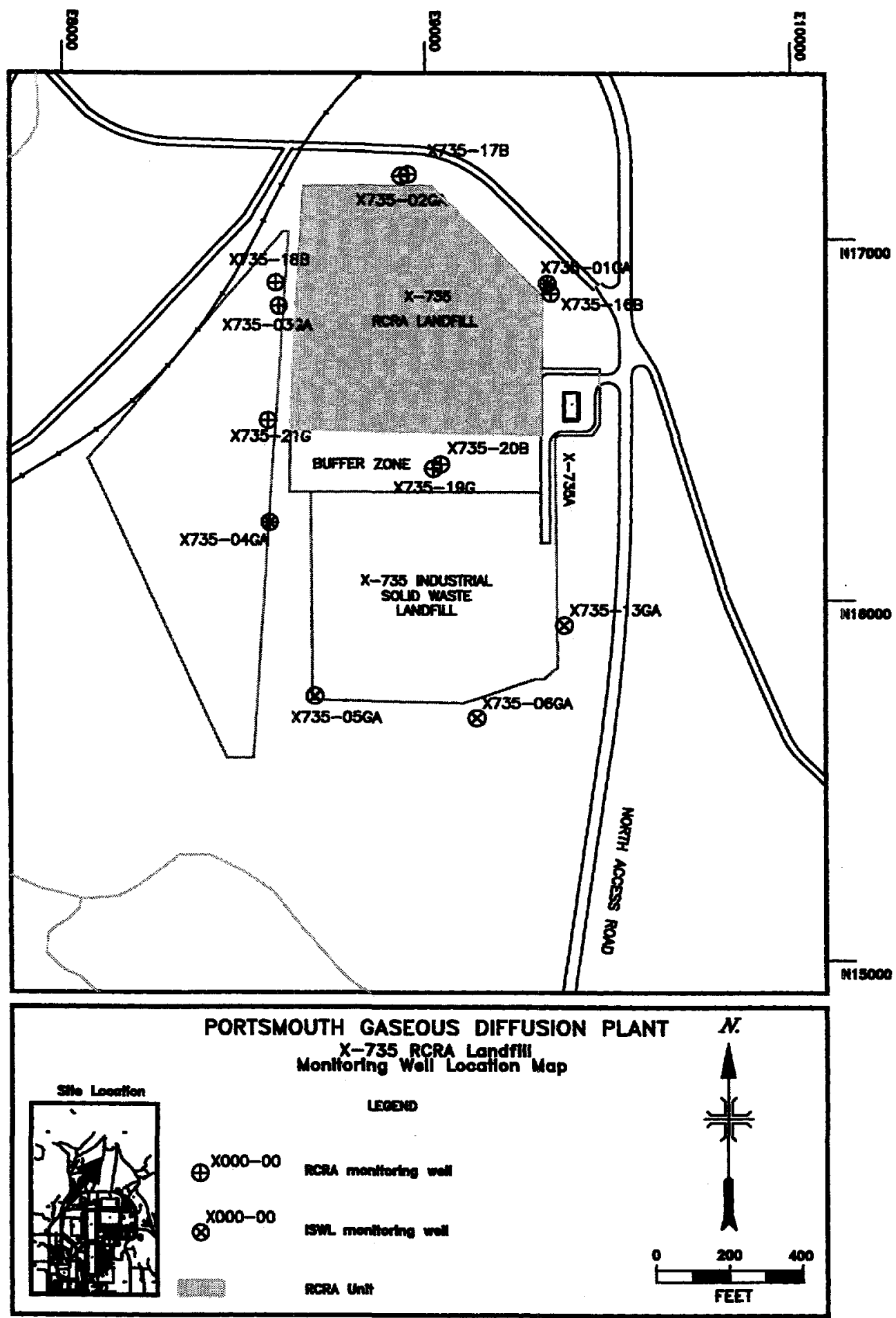

Fig. 6.3. X-735 landfill monitoring well locations.

\section{6-8 Groundwater}


respectively. The Gallia sand in the area of X-749A is comprised of sand, rounded gravel, and weathered shale fragments that range in thickness from 0 to $5 \mathrm{ft}$. Sunbury shale under the unit is approximately $10 \mathrm{ft}$ thick.

Eleven wells (Fig. 6.4) are sampled semiannually in accordance with the detection monitoring program for the unit. Analytical results from the two 1998 sampling events at the X-749A and associated statistical analyses indicate that there is no statistical difference between constituents detected in upgradient and downgradient monitoring wells. These results indicate that leachate has not been released from this unit to the groundwater.

\section{X-749 Contaminated Materials Storage Yard (Southern Portion)}

Operation of the X-749 contaminated disposal facility began in the $1950 \mathrm{~s}$, but no detailed records of the waste disposed at the unit were kept until 1976. The facility was closed in accordance with RCRA requirements; however, a closure plan for the southern portion of this unit was prepared in accordance with the solid waste regulations based on historical information about the types of wastes placed in the southern portion of the unit. The closure plan for the southern portion was approved on July 17, 1991. Closure of both the northern and southern units occurred concurrently and was completed in 1994 in accordance with both approved closure plans. Because a groundwater contaminant plume underlies both portions, the X-749 is considered a single unit for the purposes of groundwater monitoring. Thus, in this document, the term " $\mathrm{X}$ 749 " refers to the entire unit, including the north and south portions, and is discussed in the "RCRA Hazardous Waste Units" section of this chapter.

\section{RCRA HAZARDOUS WASTE UNITS}

\section{X-231B Southwest Oil Biodegradation Plot}

The X-231B southwest oil biodegradation plot, used from 1976 to 1983 for land application of waste oils and degreasing solvents, consists of two disposal plots, each surrounded by an elevated soil berm. The plots were periodically fertilized and tilled to enhance aeration and promote natural biological degradation of waste oil. Since ceasing operation in 1983, these plots have been remediated to remove volatile organic compound contamination present in the soil.

Groundwater in the Gallia in the vicinity of X-231B flows south/southeast across the site. The hydraulic gradient within the Gallia differs from north to south within the unit. The average hydraulic gradient in the north portion of the unit is $0.004 \mathrm{ft} / \mathrm{ft}$ and the average flow velocity is $0.9 \mathrm{ft} / \mathrm{day}$. The average hydraulic gradient in the south portion of the unit is $0.02 \mathrm{ft} / \mathrm{ft}$ and the average flow velocity is $43 \mathrm{ft} /$ day. The hydraulic conductivity of the Gallia for the $\mathrm{X}-231 \mathrm{~B}$ area is $62 \mathrm{ft} /$ day. The assumed effective porosity for the Gallia is $25 \%$. The hydraulic conductivity is increased by the extraction wells installed in the area to remove and control contaminated groundwater.

The Berea groundwater flow direction is similar to that of the overlying Gallia except that its gradient slopes more uniformly to the south/southeast. The hydraulic gradient for the Berea is consistently $0.006 \mathrm{ft} / \mathrm{ft}$, the mean hydraulic conductivity is $1.4 \mathrm{ft} /$ day, and a representative groundwater velocity is less than $0.1 \mathrm{ft} /$ day.

A contaminated groundwater plume consisting primarily of trichloroethene is associated with the X231B unit. Although X-231B is the unit for which monitoring is required by RCRA, many additional wells in the area are used to determine the boundaries of the plume. The contaminated plume and associated monitoring wells are depicted in Fig. 6.5.

Thirty-five monitoring wells were installed in the vicinity of the unit, 19 of which have been routinely sampled as part of the quarterly assessment monitoring program for this unit, and they have been analyzed for the parameters in Table 6.1. Assessment monitoring will continue until final closure and the initiation of postclosure monitoring. The most extensive and concentrated contaminants at X-231B are volatile organic 


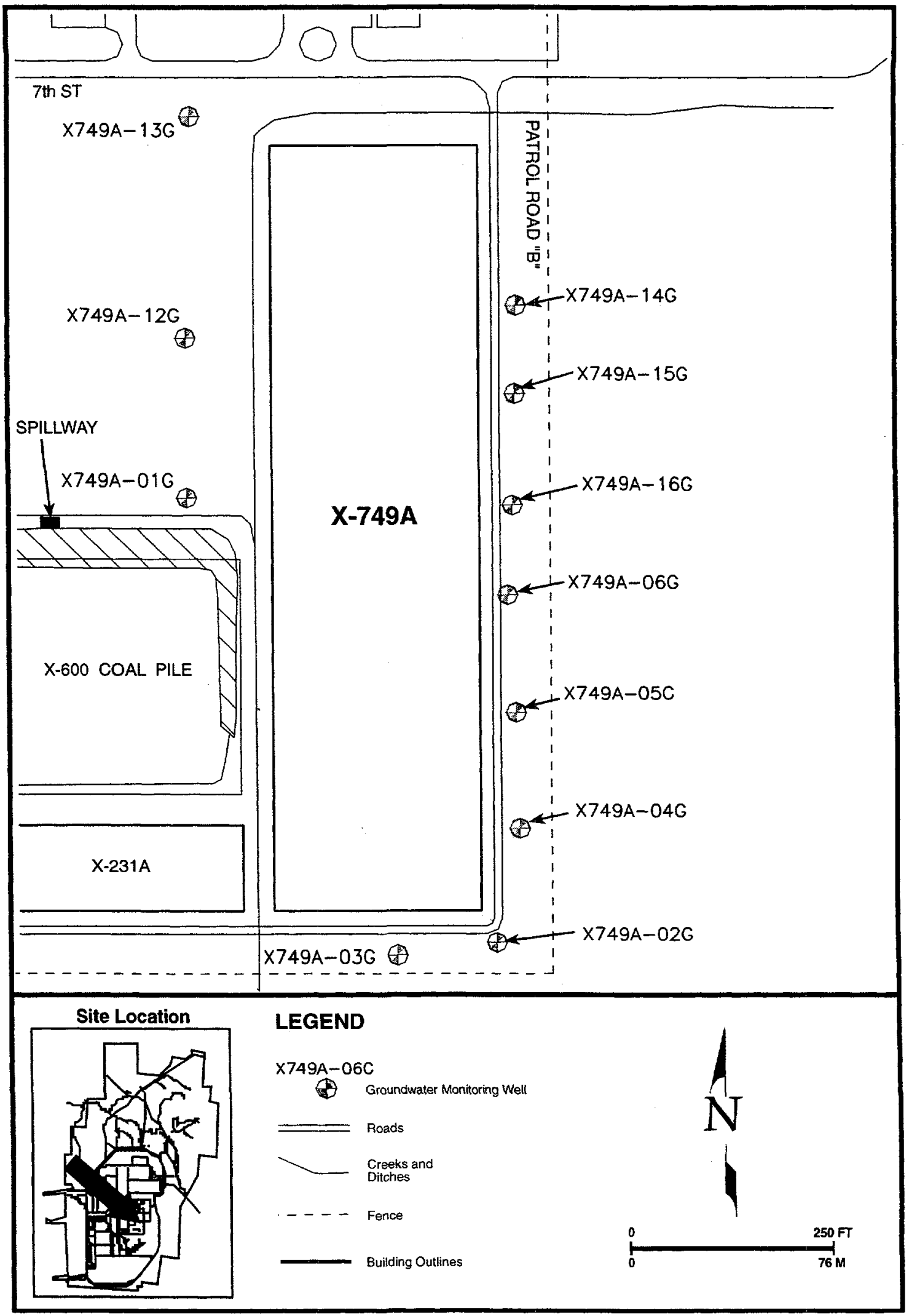

Fig. 6.4. $\mathrm{X}-749 \mathrm{~A}$ monitoring well locations.

\section{6-10 Groundwater}



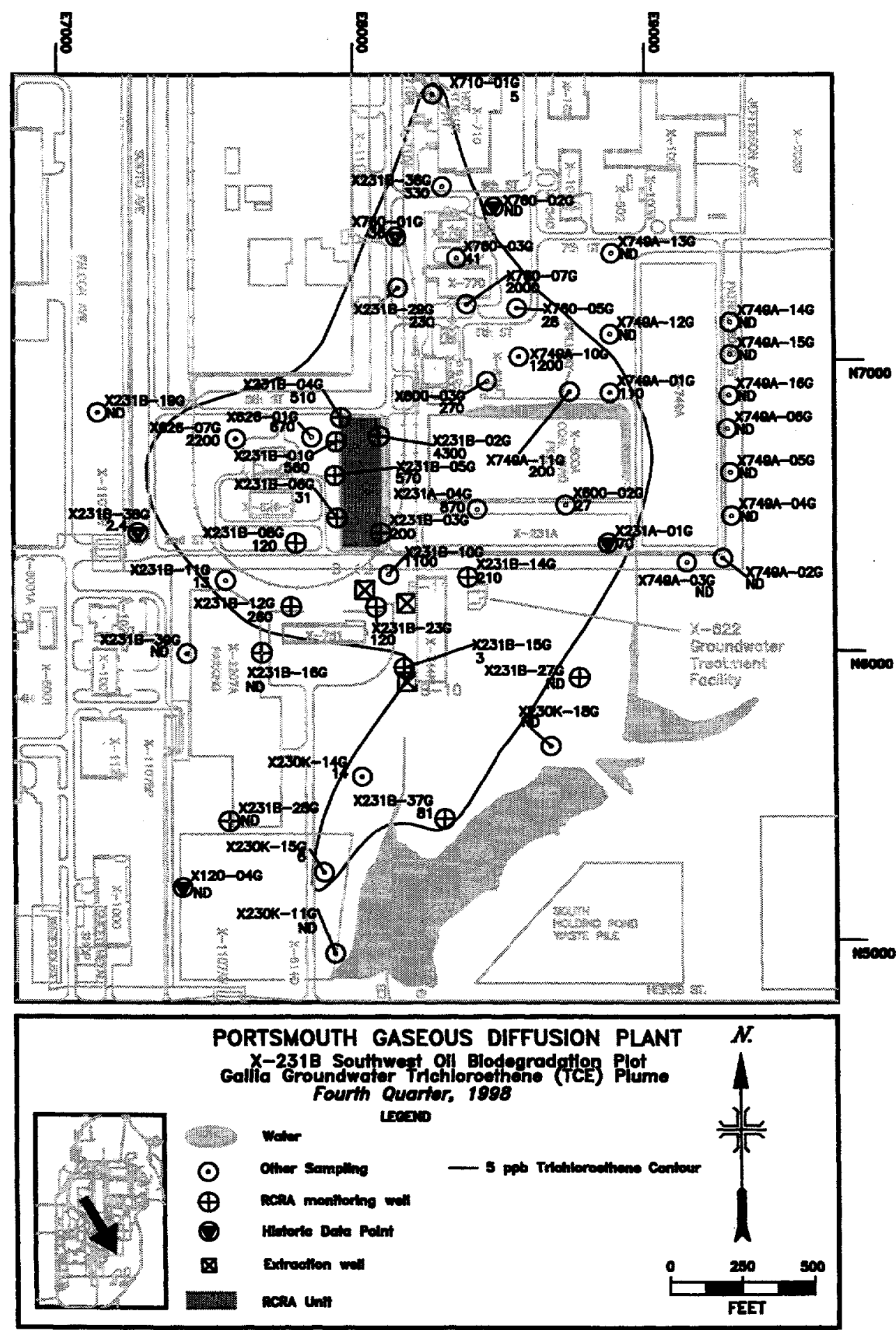

Fig. 6.5. X-231B southwest oil biodegradation plot Gallia groundwater trichloroethene plume fourth quarter, 1998. 
compounds, particularly trichloroethene and trichloreoethane. Other volatile organic compounds are also present. Inorganics (metals), uranium, and technetium are also present, but the concentrations of these constituents are below the established preliminary remediation goals and therefore do not require remediation as part of the RCRA Corrective Action process.

Three groundwater extraction wells were installed in the Gallia sand in 1991 as part of the X-231B interim remedial measure. These wells have a cumulative pumping rate of about $9 \mathrm{gal} / \mathrm{minute}$. The wells are located south (downgradient) of the X-231B unit. The extracted groundwater is treated by activated carbon filters at the X-622 south groundwater treatment facility. Assessment monitoring results indicate that the three extraction wells are locally reducing volatile organic compound concentrations in the existing groundwater contaminant plume. In 1994, soils above the groundwater (vadose zone) were treated using in situ thermal enhanced vapor extraction to remove volatile organic compounds. The process utilized an 8-ft-diameter auger to mix the vadose soils, and heated air was injected into the soils. The offgas was collected in a 12-ft-diameter shroud and transferred to a carbon absorption filter. Approximately $80 \%$ of the volatile organic compounds present in the vadose zone were removed by this treatment. An interim cap has been installed over the unit until final closure can be completed.

\section{X-616 Chromium Sludge Surface Impoundments}

The X-616 liquid effluent control facility consisted of two unlined surface impoundments used from 1976 to 1985 for storage of sludge generated by the treatment of recirculating cooling water blowdown from the PORTS process cooling system. A hexavalent chromium-based corrosion inhibitor was used in the cooling water system. The chromium in the blowdown was reduced to a trivalent chromium at the X-616 liquid effluent control facility by adding sulfur dioxide to the water, which produced sulfurous acid $\left(\mathrm{H}_{2} \mathrm{SO}_{3}\right)$. The resulting chromium hydroxide sludge was then precipitated in a clarifier by $\mathrm{pH}$ adjustment with slaked lime and a polymer coagulant. The sludge was then pumped into and stored in the X-616 impoundments. The sludge was removed from the impoundments and remediated as an interim action in 1990 and 1991. The unit was certified closed in 1993 and is in post-closure care.

Groundwater flow in the Gallia near X-616 is predominantly west and northwest toward the west drainage ditch. The reported hydraulic conductivity for the Gallia is $36.7 \mathrm{ft} /$ day. Effective porosity is assumed to be $25 \%$. The average hydraulic gradient is approximately $0.023 \mathrm{ft} / \mathrm{ft}$, with a velocity of about $3.3 \mathrm{ft} /$ day.

Groundwater flow in the Berea is primarily to the northwest. The Berea's hydraulic conductivity is about $7.5 \mathrm{ft} /$ day. Because the Sunbury shale is absent at X-616, the Gallia and Berea are in direct hydrologic communication.

Inorganic constituents including chromium, nickel, and manganese have been detected in groundwater associated with the X-616 surface impoundments. The concentrations of these constituents are below established preliminary remediation goals, however, and therefore do not require remediation as part of the RCRA Corrective Action process. Fig. 6.6 shows monitoring well locations and dissolved chromium concentrations for the second semester of 1998.

The only volatile organic compound detected above its preliminary remediation goal was trichloroethene (preliminary remediation goal of $5 \mu \mathrm{g} / \mathrm{L}$ ) in well X616-20B, with first and second sampling event results of $14 \mu \mathrm{g} / \mathrm{L}$ and $13 \mu \mathrm{g} / \mathrm{L}$, respectively.

\section{X-701B Holding Pond}

The X-701B Holding Pond was used from the beginning of plant operations in 1954 until November 1988. The pond was designed for neutralization and settlement of acid waste from several sources. Trichloroethane and trichloroethene were also discharged to the pond. Two sludge retention basins were located west of the holding pond. A contaminated groundwater plume extends from the holding pond to Little Beaver Creek (Fig. 6.7).

\section{6-12 Groundwater}




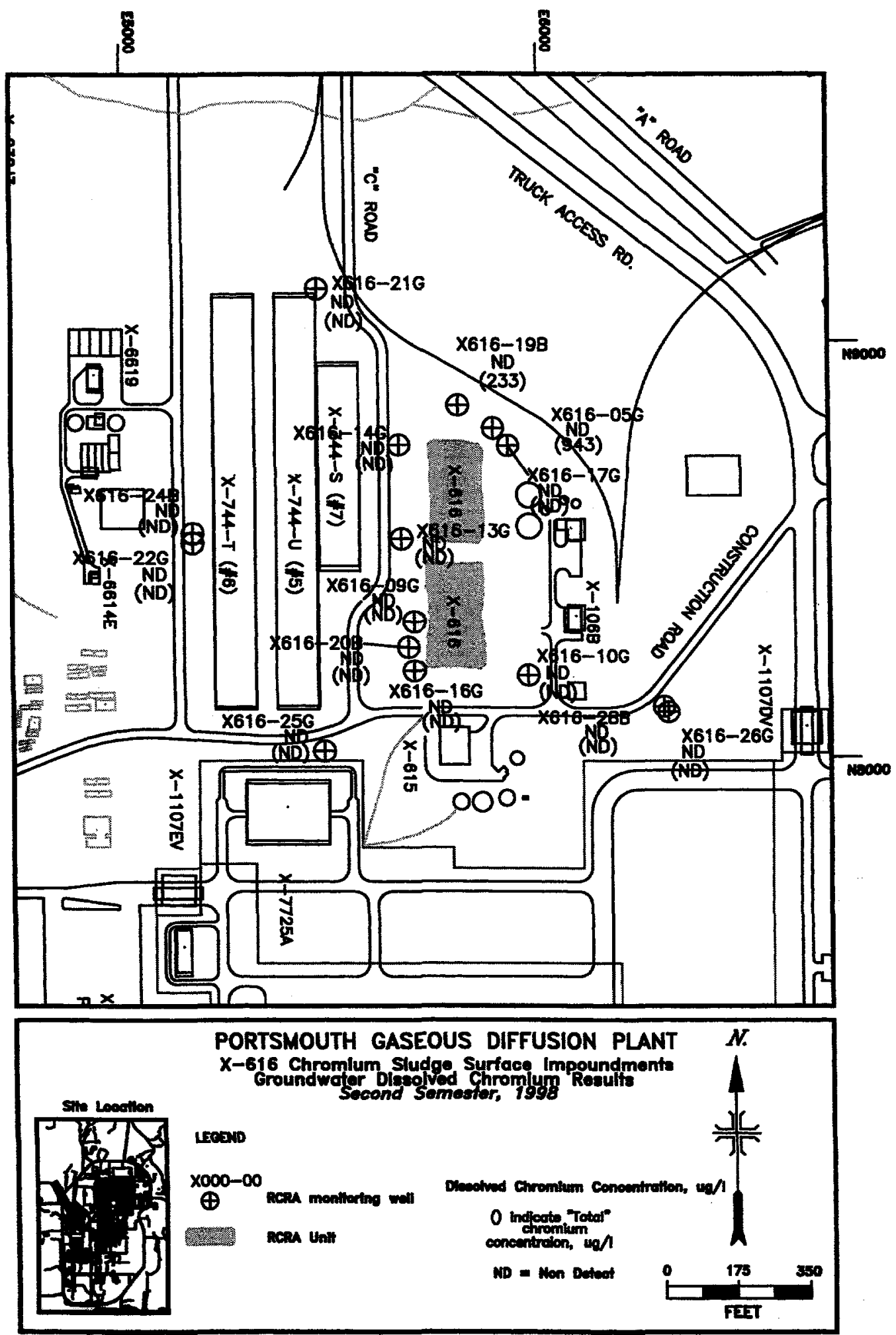

Fig. 6.6. $X-616$ chromium sludge surface impoundments dissolved chromium results second semester, 1998. 


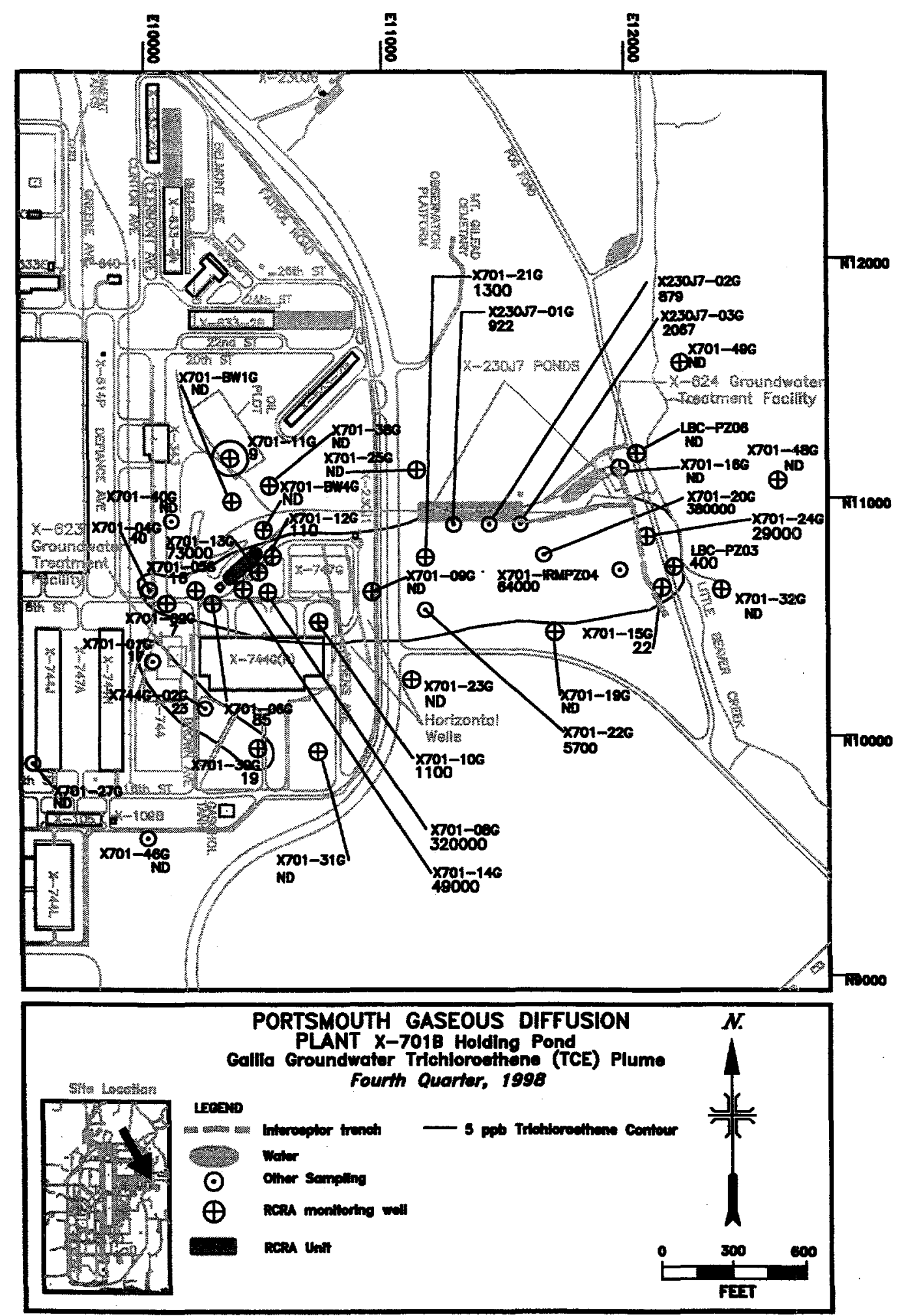

Fig. 6.7. X-701B holding pond Gallia groundwater trichloroethene plume fourth quarter, 1998. 
Groundwater in the Gallia flows eastward toward Little Beaver Creek, and the flow converges from both the north and the south, forcing a narrowing of flow. The measured hydraulic conductivities for the Gallia range two orders of magnitude from $0.5 \mathrm{ft} /$ day to $57.5 \mathrm{ft} /$ day. There are two distinct hydraulic gradients. The steeper hydraulic gradient is near the X-237 trench and X-230J7 pond. Groundwater in the Berea flows across the site from the west to east toward Little Beaver Creek. The eastward-dipping Berea unit is confined due to the overlying Sunbury shale, which ranges from 10 to $15 \mathrm{ft}$ in thickness across X-701B. The mean hydraulic conductivity for the Berea sandstone is $2.5 \mathrm{ft} /$ day.

Several groundwater investigations have occurred at this unit and have included the installation of over 100 groundwater monitoring wells. Thirty of these wells have been selected for quarterly assessment sampling at this unit. Twenty-seven Gallia wells and three Berea sandstone wells were analyzed for parameters listed in Table 6.1. Laboratory analyses of the groundwater samples identified several volatile organic compounds that will require remediation as part of the RCRA Corrective Action process. No volatile organic compounds were detected in the monitoring wells sampled north of the plume area or at any of the Little Beaver Creek sampling locations.

Inorganics (metals) and radiological constituents (uranium and technetium) have also been detected in the groundwater beneath the X-701B area. These constituents are being evaluated during a special study initiated in 1998 and scheduled for completion in 1999. Based on the results of the special study, remediation of these constituents may be required as part of the RCRA Corrective Action process at the X-701B.

An additional area of trichloroethene contamination was identified in 1998. This apparently isolated and crescent-shaped plume (see Fig. 6.7) is believed to be separate from and unrelated to the X-70lB area. Flow data for this new plume indicates the flow direction is to the northeast, or toward the main X-701B plume. This flow data and historical sampling data support the theory that this new plume is unrelated to the main X-701B plume.

Three groundwater extraction wells were installed southeast of X-701B as part of the ongoing RCRA closure of the unit. These wells were designed to intercept contaminated groundwater emanating from the holding pond area before it could join the existing groundwater contaminant plume. Extracted groundwater is processed at the X-623 groundwater treatment facility. This facility also processes water recovered from a shallow sump in the bottom of the X-701B holding pond. Two groundwater interceptor trenches (French drains) are used to intercept trichloroethene-contaminated groundwater emanating from X-701B. The X-237 groundwater collection system has significantly reduced trichloroethene migration into Little Beaver Creek. The 660-foot-long primary trench has two extraction wells completed in the backfill, and a 440-foot-long secondary trench intersects the primary trench. The extracted groundwater is treated at the X-624 groundwater treatment facility.

\section{X-701C Neutralization Pit}

The $\mathrm{X}-701 \mathrm{C}$ unit consists of a neutralization pit and a pump pit. The neutralization pit is $18 \mathrm{ft}$ deep and has horizontal dimensions of $25 \mathrm{ft}$ by $25 \mathrm{ft}$. The floors and walls are constructed of concrete and are lined with acid-proof brick. A sump in the bottom of the neutralization pit formerly discharged into an adjacent pump pit. The concrete pump pit is $9 \mathrm{ft}$ deep and covers approximately 81 square $\mathrm{ft}$. This unit is currently undergoing closure integration with the RCRA corrective action process.

Groundwater flow in the vicinity of the $\mathrm{X}-701 \mathrm{C}$ is to the west toward the $\mathrm{X}-700$ building. The hydraulic gradient is induced by means of sump pumps in the X-700 and X-705 buildings. A local cone of depression has been established around the buildings. This is a local reversal of the natural hydraulic gradient; typically, the natural hydraulic gradient is to the east toward Little Beaver Creek. The 1998 hydraulic gradient for the X-701C site ranged from $0.011 \mathrm{ft} / \mathrm{ft}$ to $0.015 \mathrm{ft} / \mathrm{ft}$. The Gallia effective porosity is assumed to be $25 \%$. Using these values, the average linear velocities ranged from $1.5 \mathrm{ft} /$ day to $2.2 \mathrm{ft} /$ day. The hydraulic conductivity is $36.8 \mathrm{ft} /$ day. 
The X-701C neutralization pit is located within a trichloroethene plume centered around the X-700 chemical cleaning facility and the X-705 decontamination building. The extent of the plume (Fig. 6.8) has been determined by monitoring several wells in the surrounding areas. The Ohio EPA directed DOE/PORTS to conduct detection monitoring to determine whether the $\mathrm{X}-701 \mathrm{C}$ neutralization pit has been releasing hazardous constituents into the groundwater. The detection monitoring plan is not typical because of the size of $\mathrm{X}-701 \mathrm{C}$ and its location in the existing contaminated plume. If the $\mathrm{X}-701 \mathrm{C}$ is determined to be a source of contamination, the pit will be removed or remediated.

Detection monitoring at X-701C is conducted semiannually and utilizes the three existing wells installed into the Gallia sand. Samples are analyzed for parameters listed in Table 6.1. The primary groundwater contaminant, trichloroethene, was detected above the preliminary remediation goal in all three monitoring wells, with the highest concentrations occurring in the upgradient well. Dichloroethene was also detected above its preliminary remediation goal in 1998. Remediation of the groundwater contaminated with volatile organic compounds will be completed as part of the RCRA Corrective Action process in this area. Inorganics (metals) have also been detected in the groundwater beneath the X-701C area. These constituents are being evaluated during a special study initiated in 1998 and scheduled for completion in 1999. Based on the results of the special study, remediation of these constituents may be required as part of the RCRA Corrective Action process at the X-701C. No radiological constituents were detected above preliminary remediation goals.

As part of the detection monitoring program at the X-701C, statistical analyses are performed on analytical data collected from the X-701C monitoring wells to determine whether the X-701C unit is affecting downgradient monitoring wells. Statistical analysis of some data and qualitative review of other data indicates that the downgradient wells are not being negatively impacted by the X-701C unit.

\section{X-735 RCRA Landfill (Northern Portion)}

The X-735 landfill, located at the northern end of the Portsmouth reservation, began operation in September 1981. The unit was approved by the Ohio EPA and the Pike County Health Department for disposal of nonhazardous nonradioactive solid wastes. In 1991, wipe rags potentially contaminated with solvents were inadvertently disposed in cells one through six at the northern end of the landfill. This portion of X-735 was subsequently closed as a RCRA hazardous waste landfill. The southern portion of X-735, which is the industrial solid waste facility (Fig. 6.3), ceased operations on December 31, 1997. Closure of the industrial solid waste landfill was completed in 1998.

In the vicinity of the X-735, groundwater flow in the Gallia is generally east to west; however, the very low potentiometric surface gradient results in flow direction fluctuations. Little Beaver Creek to the south and a tributary of Little Beaver Creek to the west of X-735 locally influence the direction of groundwater flow in the northern and southern parts of the landfill area. In the northern portion, groundwater flow is toward the west and northwest. The representative east-west hydraulic gradient was $0.001 \mathrm{ft} / \mathrm{ft}$ for the sampling events in 1998 . The hydraulic conductivity ranges from $1,440 \mathrm{ft} /$ day to $4.3 \mathrm{ft} /$ day. The arithmetic mean hydraulic conductivity value of $430 \mathrm{ft} /$ day is used in determining groundwater flow velocity for the Gallia. The effective porosity for the Gallia is assumed to be $25 \%$. These values yield a groundwater flow rate range of $3.4 \mathrm{ft} /$ day to $10.3 \mathrm{ft} /$ day. The representative east-west hydraulic gradient for the Berea at X-735 ranged from $0.002 \mathrm{ft} / \mathrm{ft}$ to $0.006 \mathrm{ft} / \mathrm{ft}$. The potentiometric head in the Gallia and Berea are about the same in the northern portion and eastern side of the landfill. A slight upward vertical gradient from the Berea sandstone into the Gallia sand, however, is indicated in wells south of the X-735 RCRA landfill.

Ten wells, two of which are also included in the monitoring program for the industrial solid waste landfill, are sampled quarterly for detection monitoring at the X-735 RCRA landfill and are analyzed for the parameters listed in Table 6.1. Dedicated bladder pumps and low-flow sampling techniques were used to collect samples in 1998. No volatile organic compounds were detected in the X-735 wells in 1998.

\section{6-16 Groundwater}




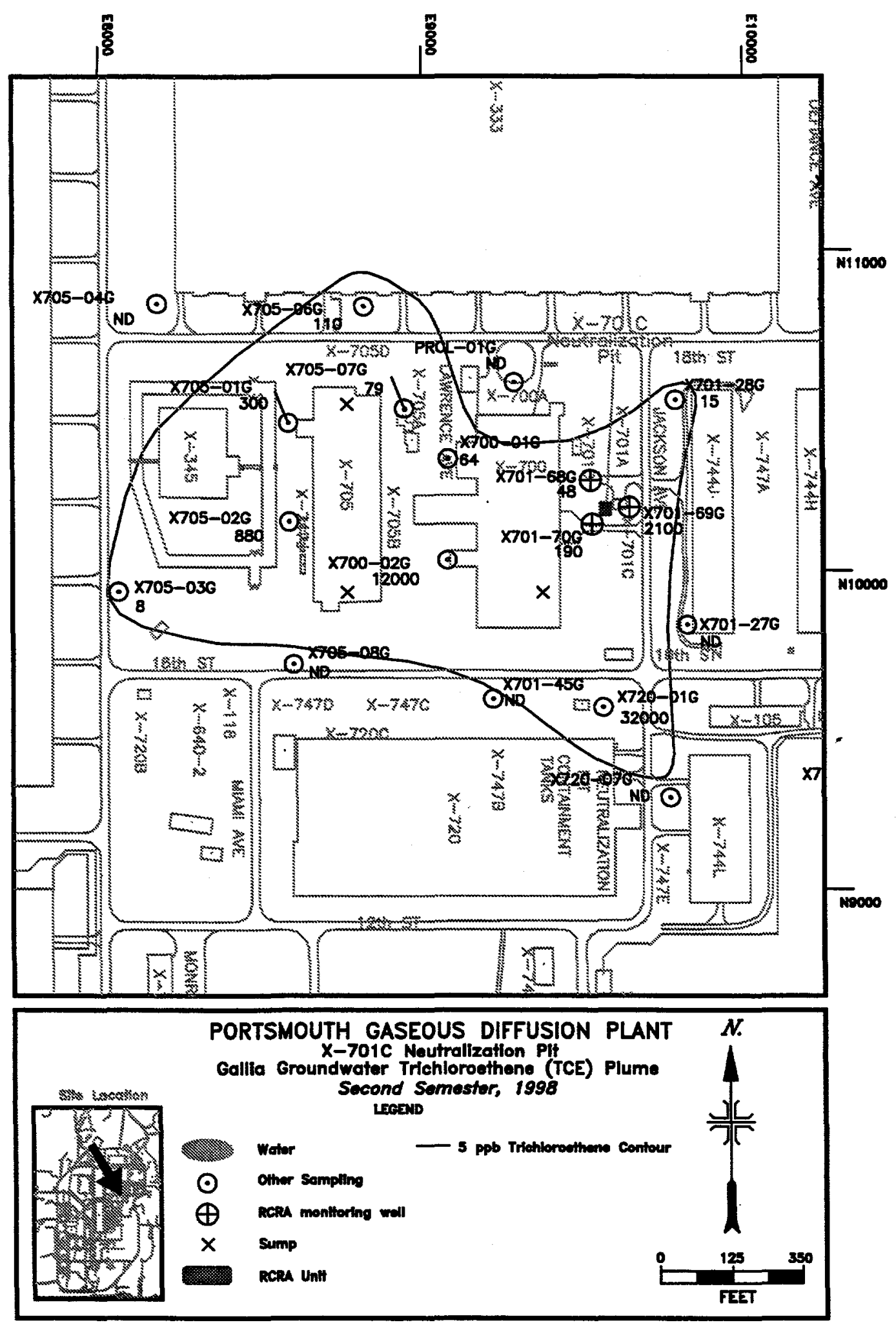

Fig. 6.8. X-701C neutralization pit Gallia groundwater trichloroethene plume second semester, 1998. 
Analytical data from X-735 monitoring wells were also statistically evaluated to determine whether releases from the X-735 unit have occurred. Results of the statistical evaluation for 1998 indicate that there have been no releases from the X-735 to the underlying groundwater.

\section{X-749 Contaminated Materials Storage Yard (Northern Portion)}

The X-749 contaminated materials storage yard is located in the south-central area of the site. This landfill, covering approximately 7.5 acres, was built in an area of highest elevation within the southern half of the facility. During operation of the landfill from 1955 through 1990, buried wastes were generally contained in metal drums or other compatible containers. The landfill was divided into northern and southern portions. The northern portion, measuring approximately 200,000 square $\mathrm{ft}$, contains waste contaminated with industrial solvents, waste oils from plant compressors and pumps, and hazardous and low-level radioactive sludges. The northern portion was closed in accordance with RCRA Subtitle $\mathrm{C}$ requirements. The southern portion is approximately 130,000 square $\mathrm{ft}$ and contains nonhazardous, low-level fixed, and possibly transferable radioactive scrap materials. Because a groundwater contaminant plume (Fig. 6.9) underlies both portions, which are adjacent and were closed simultaneously, the $X-749$ is considered a single unit for the purposes of groundwater monitoring.

The facility was closed in 1992 in accordance with RCRA requirements. Closure consisted of the installation of a multimedia cap, a slurry wall along the north side and northwest corner of the unit, subsurface groundwater drains on the northern half of the east side and southwest corner of the unit, and one groundwater extraction well within each of the drains. The groundwater collected by the extraction wells is pumped to the X-622 south groundwater treatment facility, which is an activated carbon filtration system. In 1994, an interim remedial measure subsurface diversion wall was completed across a portion of the facility's southern boundary to prevent plume migration off plant property prior to implementation of a final remedial measure for groundwater.

The X-749 area contains three groundwater flow zones with three distinct hydraulic gradients: a steeper gradient to the east and more gradual gradients to the south and west. Hydraulic conductivities of 5.0 $\mathrm{ft} /$ day (east), $4.13 \mathrm{ft} /$ day (west), and $6.0 \mathrm{ft} /$ day (south) for these areas were used to calculate average linear velocities. The effective porosity is $30 \%$. There are two distinct hydraulic gradients in the Berea: a steeper gradient to the east near Big Run Creek, and a more gradual gradient to the south and west. The hydraulic conductivity value is $1.0 \mathrm{ft} /$ day for the Berea. The effective porosity is $10 \%$. As expected, groundwater flow velocities in the Berea are lower than those recorded for the Gallia.

Six Berea wells and 23 Gallia wells are sampled semi-annually. The most extensive and most concentrated constituents at X-749 were volatile organic compounds, particularly trichloroethene and trichloroethane. Remediation of these constituents may be required as part of the RCRA Corrective Action process.

Inorganics (metals) and radiological constituents (uranium and technetium) have also been detected in the groundwater beneath the X-749 area. These constituents are being evaluated during a special study initiated in 1998 and scheduled for completion in 1999. Based on the results of the special study, remediation of these constituents may be required as part of the RCRA Corrective Action process at the X-749.

\section{RCRA CORRECTIVE ACTION UNITS}

The RCRA Corrective Action Program at PORTS has identified two units that required groundwater monitoring in 1998 as part of the Corrective Measures Implementation for the units. Operation and Maintenance Plans for the units provide the operation and maintenance procedures for the units as well as the groundwater monitoring requirements.

\section{6-18 Groundwater}



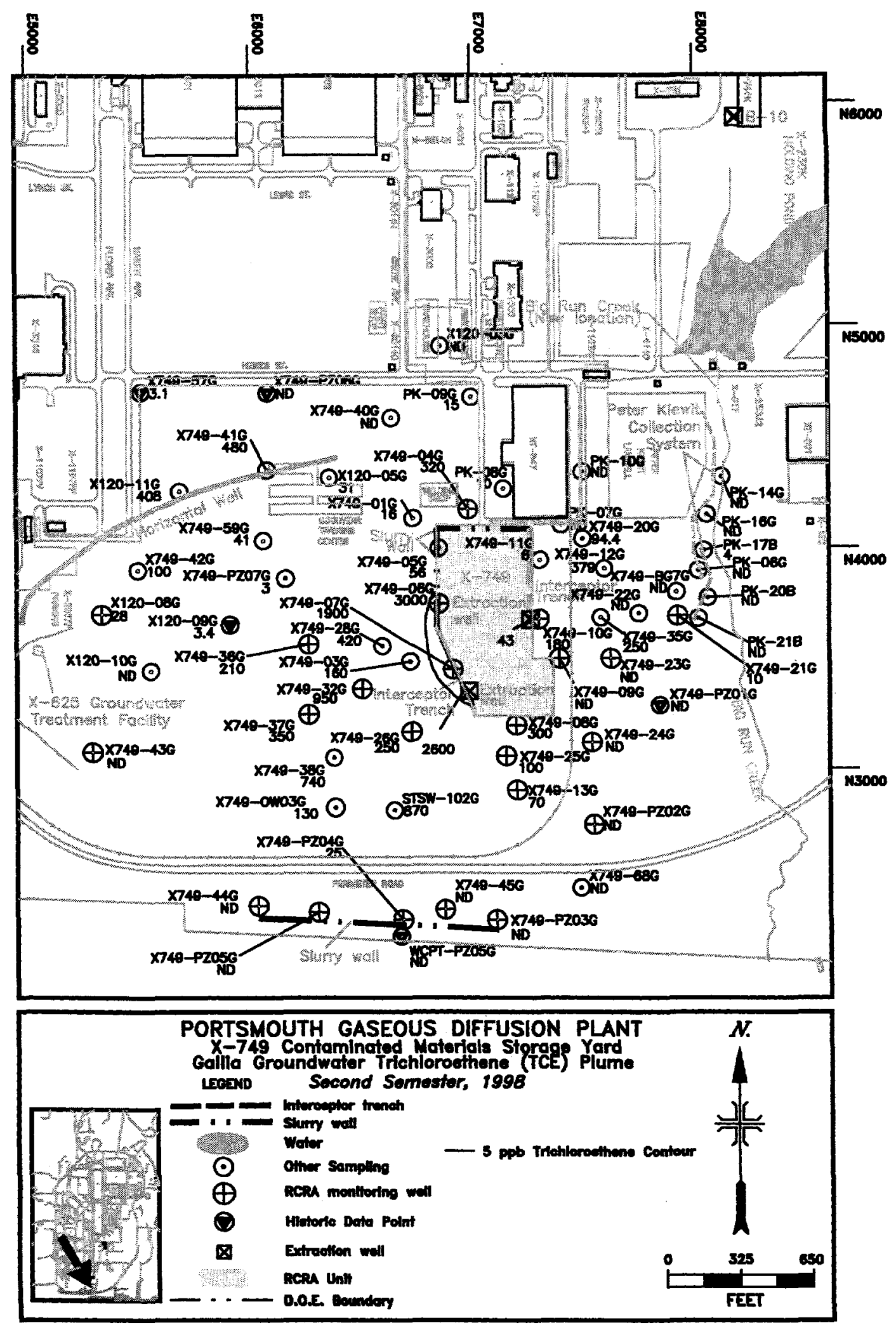

Fig. 6.9. X-749 contaminated materials storage yard Gallia groundwater trichlorethene plume second semester, 1998. 


\section{X-611A Lime Sludge Lagoons}

The X-611A Lime Sludge Lagoons are three adjacent unlined sludge retention lagoons constructed in 1954 and used for disposal of lime sludge waste from the site water treatment plant from 1954 to 1960 . The lagoons, which had a capacity of approximately 295,000 cubic yards, are in the RCRA Corrective Action Quadrant IV. The lagoons were constructed in a low-lying area that included Little Beaver Creek. As a result, approximately 1500 feet of Little Beaver Creek was relocated to a channel just east of the lagoons.

The Phase I and Phase II Quadrant IV RCRA Facility Investigation in 1992 and 1994 identified the X611A Lime Sludge lagoons as candidates for a corrective measure. The Corrective Measures Study for the unit identified alternatives to remediate the unit, and construction of a pre-engineered prairie habitat was selected. Construction of the prairie habitat included placing a soil cover over the lagoons, contouring the area for water management, and establishing prairie vegetation.

Six monitoring wells are installed around the perimeter of the X-611A Lime Sludge Lagoons (Fig. 6.10) and are sampled semiannually for beryllium, chromium, and polychlorinated biphenyls. Groundwater monitoring at the X-611A will continue, with an evaluation scheduled for 2002 to determine whether the construction of the prairie habitat has been effective.

\section{X-749B Peter Kiewit Landfill}

The X-749B Peter Kiewit Landfill is located in the southern portion of the PORTS reservation along the west side of Big Run Creek, immediately north and east of the X-749 Contaminated Materials Storage Yard. The landfill was used from approximately 1953 to 1968 . During plant construction, the area was used as a salvage yard, burn pit, and trash disposal area. After plant construction, the area became a sanitary landfill.

As part of the Quadrant I RCRA Facility Investigation in 1990, surface seeps were observed along the eastern boundary of the landfill. In 1993, analytical data from samples of the seeps indicated the presence of contaminants in the water. An interim remedial measure was implemented to eliminate seep runoff to Big Run Creek that included rerouting the creek to the east and constructing a seep collection/treatment system in the original creek bed adjacent to the seeps. A Cleanup Alternatives Study/Corrective Measures Study for the landfill evaluated alternatives for remediating the site. The alternative selected by the Ohio EPA and U.S. EPA included capping the landfill and continued operation of the seep collection system. An extension of the existing seep collection system was also installed on the southeastern boundary of the unit.

The landfill cap was installed on the unit in 1998. Samples are collected from ten monitoring wells (see Fig. 6.11) with analysis for volatile organic compounds, radionuclides, metals, and polychlorinated biphenyls. The first of four quarterly monitoring events was completed during the fourth quarter of 1998 . Volatile organic compounds, metals, technetium, and uranium were detected in Gallia and Berea groundwater wells in 1998. Groundwater analytical data from 1999 will be compared to 1998 data to determine whether the X-749B Peter Kiewit Landfill is contributing to the X-749 groundwater plume, and to monitor the seep collection and groundwater treatment systems.

\section{SURVEILLANCE MONITORING PROGRAM}

The surveillance monitoring program at DOE/PORTS consists of perimeter exit pathway monitoring, off-site water supply sampling, PORTS water supply sampling, and baseline monitoring. Perimeter monitoring assesses the effect of the facility on regional groundwater quality and quantity. Off-site sampling and the PORTS water supply sampling provide information about any impact DOE/PORTS operations may have on the quality of the drinking water supply. Baseline monitoring is conducted to establish baseline data.

\section{6-20 Groundwater}



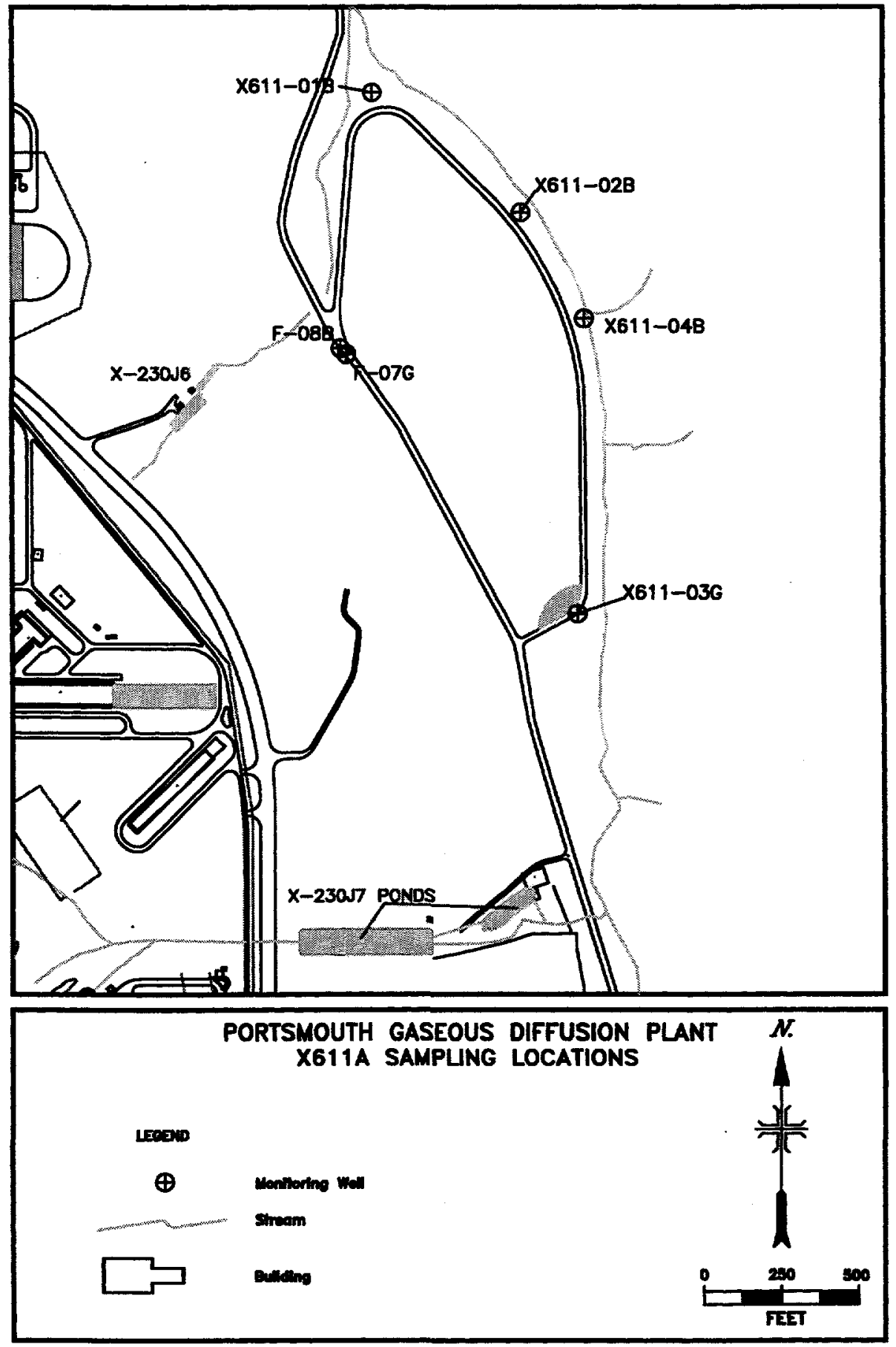

Fig. 6.10. $X-611 \mathrm{~A}$ lime sludge lagoons monitoring well locations. 

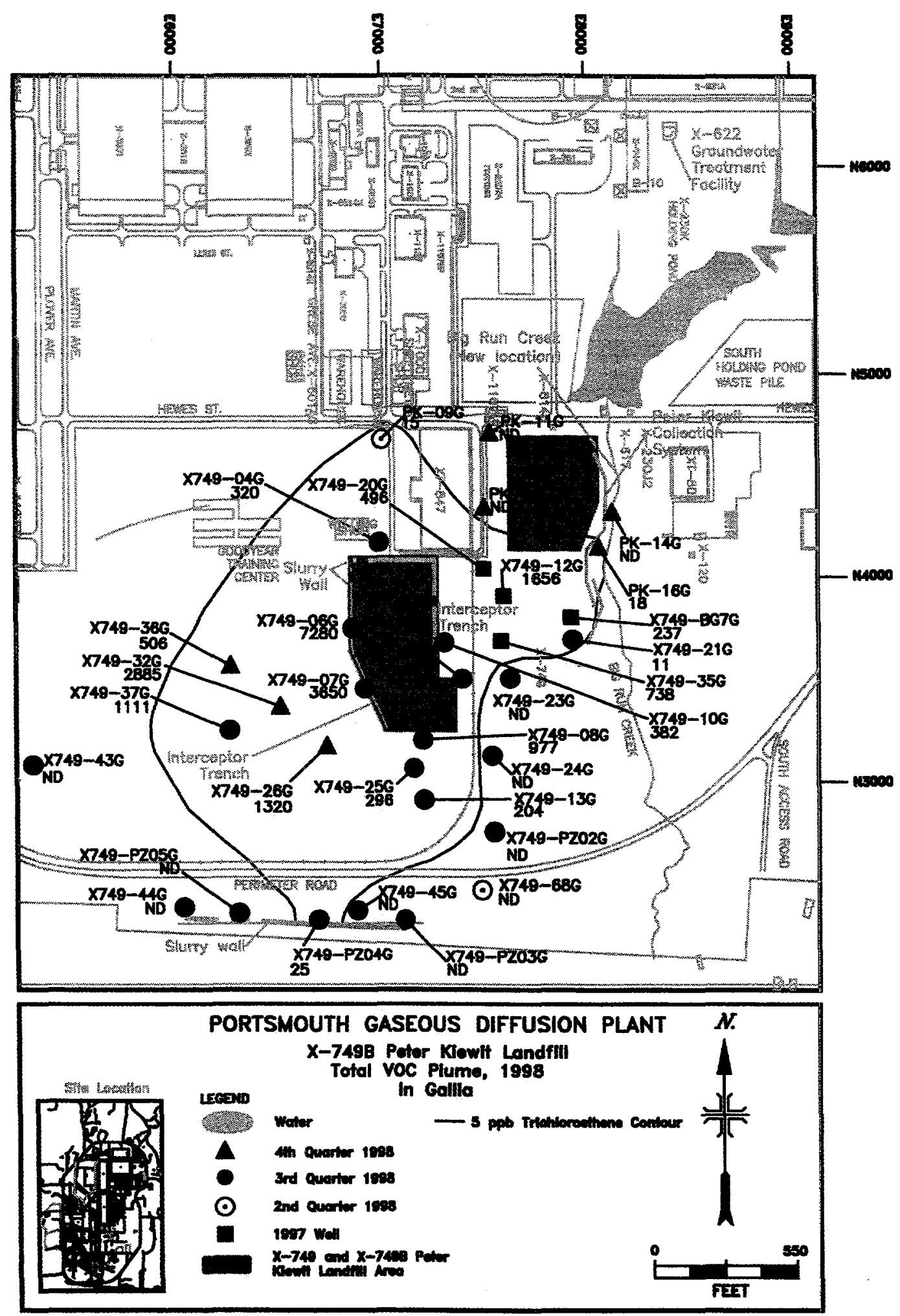

Fig. 6.11. X-749B Peter Klewit landfill monitoring wells and Gallia trichloroethene plume fourth quarter 1998. 


\section{Perimeter Exit Pathway Monitoring}

Groundwater investigations have determined that the Gallia sand is the primary hydrogeologic unit for contaminant migration at DOE/PORTS. The Gallia sand is not a regionally persistent unit because of the topography on which it was deposited, as well as its depositional environment. Selected locations on local streams and drainage channels near the reservation boundary are sampling points of the surveillance monitoring program because groundwater discharges to these surface waters. Monitoring wells near the reservation boundary are also used in the surveillance monitoring program. Fig. 6.12 shows the sampling locations for exit pathway monitoring.

\section{Baseline Monitoring}

Four well clusters, each composed of one well completed in the Gallia sand and one well completed in the Berea sandstone, are sampled annually to determine baseline water quality (Fig. 6.12). Sampling is conducted to provide a comparison between on-site wells and wells that represent background water quality.

\section{Off-Site Sampling}

The purpose of the off-site sampling program is to verify that drinking water sources have not been adversely affected by DOE/PORTS operations. Although this program may provide an indication of contaminant transport off site, it should not be interpreted as an extension of the on-site groundwater monitoring program, which bears the responsibility for detecting contaminants and determining the rate and extent of contaminant movement. Because little is known about how residential wells were constructed and about the pumps used in residential wells, data from this program is not used in hydrogeologic or geochemical investigations.

In 1998, five residents participated in the program (see Fig. 6.13 for sampling locations and Table 6.1 for the analytical parameters). All sampling for the residential program is conducted semiannually. Sampling locations are added or deleted at the request of residents and as program requirements dictate. Typically, sampling locations are deleted when a resident obtains access to the public water supply. Sampling locations are added on request and if there is a probable hydrogeologic connection between DOE/PORTS and a resident's water supply. Residential sampling to date indicates that DOE/PORTS is not affecting residential water supplies.

The PORTS water supply is also sampled as part of the off-site Sampling Program. Sampling results for 1998 indicate that DOE/PORTS operations have not affected the water supply.

\section{GROUNDWATER TREATMENT UNITS}

In 1998, a combined total of approximately 23.8 million gallons of contaminated groundwater was treated at the X-622, X-622T, X-623, X-624, and X-625 groundwater treatment facilities. Approximately 156 gallons of trichloroethene were removed from the groundwater. All processed water is discharged through NPDES outfalls before exiting PORTS.

\section{X-622 Groundwater Treatment Facility}

The groundwater treatment method used at the X-622 groundwater treatment facility is activated carbon and green sand filtration of the contaminated groundwater. Trichloroethene-contaminated groundwater from the X-231B southwest oil biodegradation plot, the X-749 contaminated materials disposal facility, and the Peter Kiewit groundwater collection system are processed at this treatment unit. In 1998, the unit 


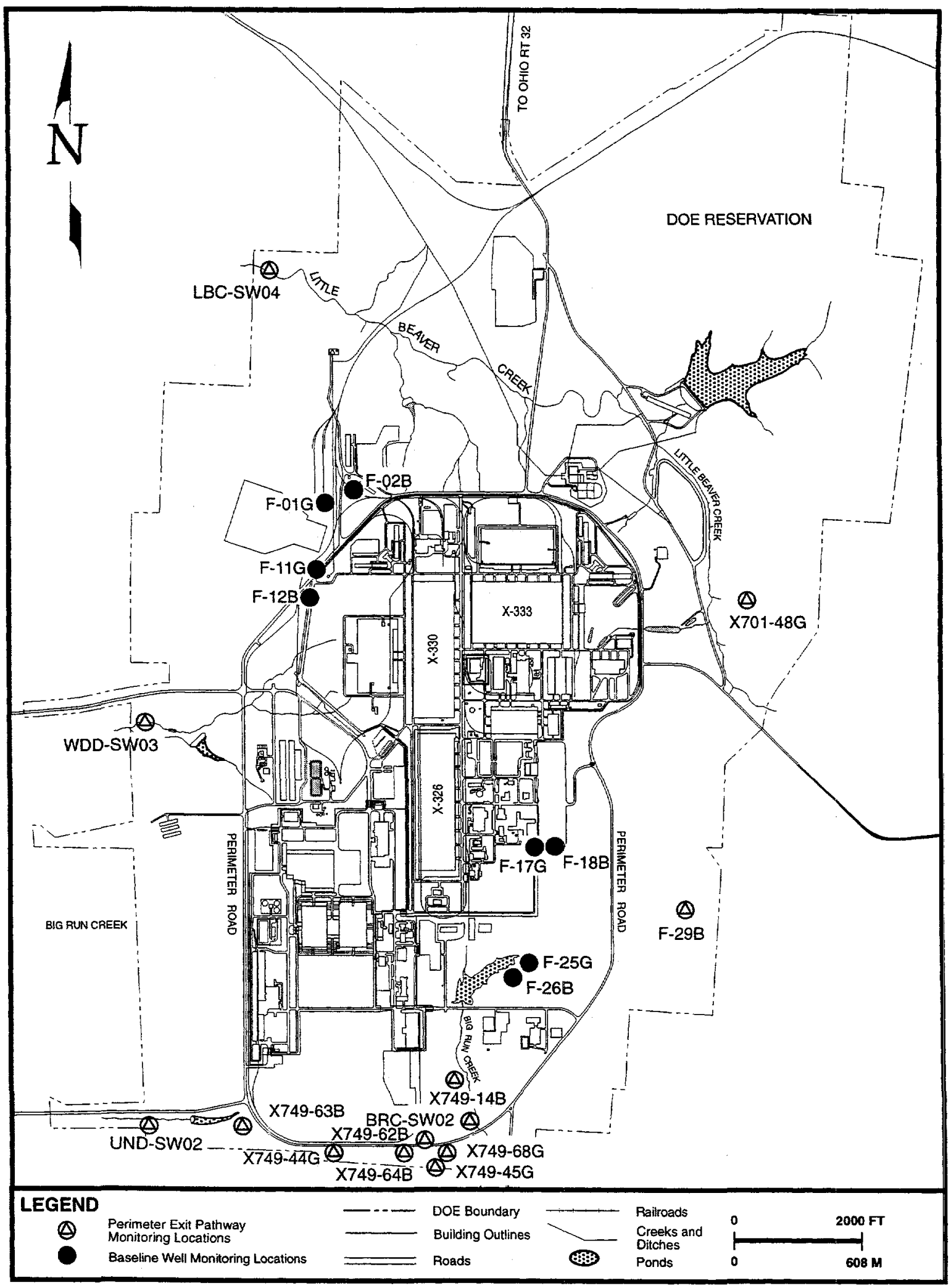

Fig. 6.12. Perimeter exit pathway and baseline monitoring locations at DOE/PORTS. 


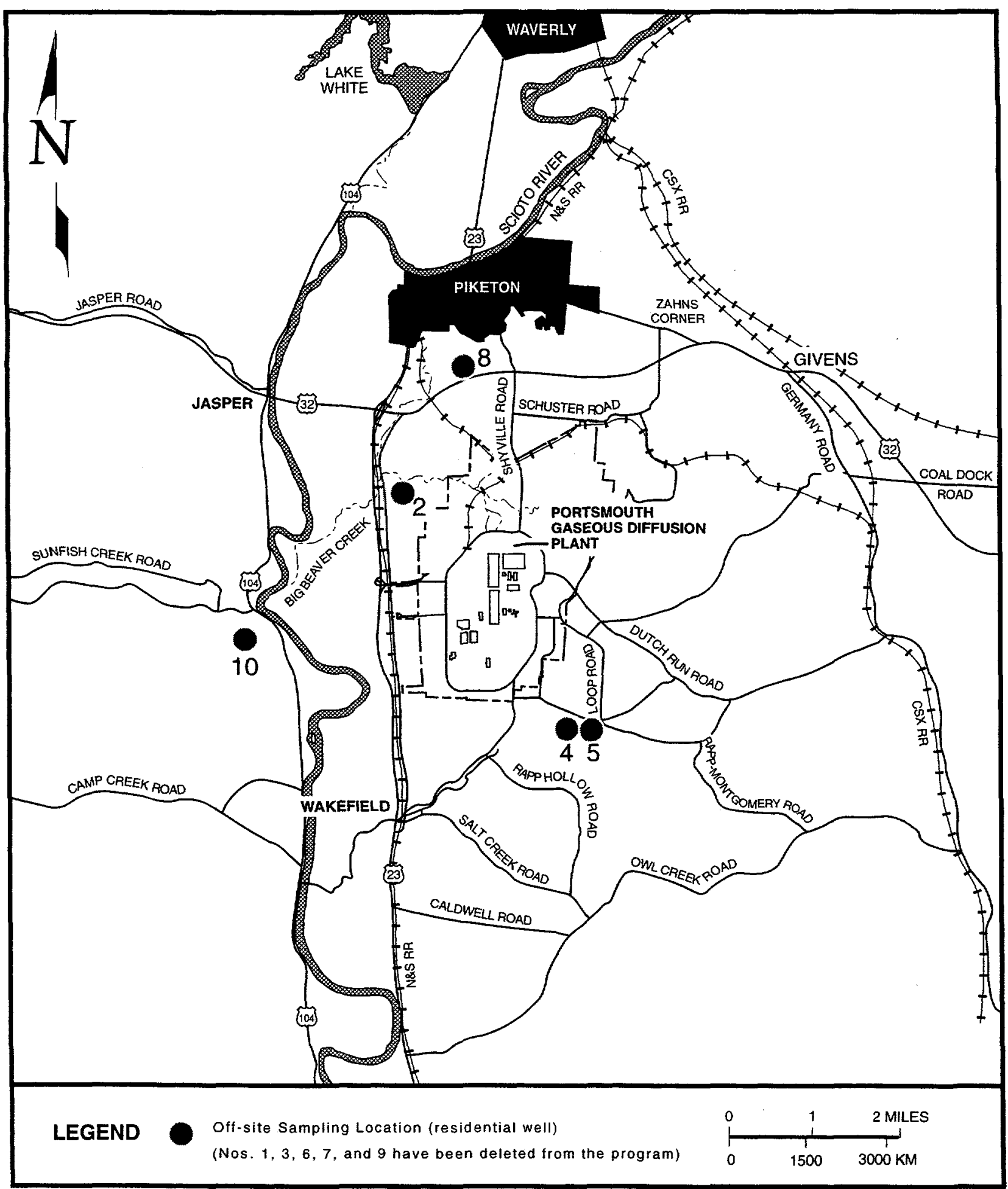

Fig. 6.13. Portsmouth off-site sampling locations. 
processed approximately 8.8 million gallons of groundwater, removing 2 gallons of trichloroethene from the water.

One sample of water entering the X-622 Groundwater Treatment Facility was analyzed for americium241 , plutonium-238, and plutonium-239/240 in 1998 . None of these constituents were detected in the sample.

\section{X-622T Groundwater Treatment Facility}

At the X-622T treatment facility, activated carbon is used to treat contaminated groundwater from the $X-700$ chemical cleaning facility and the X-705 decontamination building. The X-700 and X-705 buildings are located above a volatile organic compound contaminant groundwater plume, and contaminated groundwater is extracted from sumps located in the basement of each building. In 1998, approximately 9.4 million gallons of groundwater were processed, thereby removing 16 gallons of trichloroethene from the water.

One sample of water entering the X-622T Groundwater Treatment Facility and one sample of water exiting the facility were analyzed for americium-241, plutonium-238, and plutonium-239/240 in 1998 . None of these constituents were detected in the samples.

\section{X-623 Groundwater Treatment Facility}

The X-623 groundwater treatment facility consists of an air stripper with offgas activated carbon filtration and aqueous phase activated carbon filtration. The X-623 groundwater treatment facility provides treatment for trichloroethene-contaminated groundwater from the X-701B holding pond and three groundwater extraction wells in the X-701B plume area. The facility treated approximately 2.1 million gallons of water in 1998, thereby removing 89 gallons of trichloroethene from the water.

One sample of water entering the X-623 Groundwater Treatment Facility and one sample of water exiting the facility were analyzed for americium-241, plutonium-238, and plutonium-239/240 in 1998 . None of these constituents were detected in the samples.

\section{X-624 Groundwater Treatment Facility}

At the X-624 groundwater treatment facility, groundwater is treated via an air stripper with offgas activated carbon filtration plus carbon filtration of the effluent water. This facility processes trichloroethenecontaminated groundwater from the X-237 interceptor trench associated with the X-701B plume. In 1998, about 3.2 million gallons of groundwater were treated, thereby removing 49 gallons of trichloroethene from the water.

\section{X-625 Groundwater Treatment Facility}

At the X-625 treatment facility, groundwater is gravity-fed from a horizontal well associated with the $\mathrm{X}-749 / \mathrm{X}-120$ groundwater plume. As part of an ongoing technology demonstration, water is treated with various passive media such as iron filings. (See Chapter 3, "Environmental Programs," for details.) In 1998, approximately 226,000 gallons of groundwater were treated.

\section{SURFACE WATER MONITORING}

Surface water monitoring is conducted in conjunction with groundwater assessment monitoring to help determine whether groundwater contaminants are seeping into streams. Note that dilution of groundwater inflow by the streams may make the contaminants undetectable in surface water samples. Surface water is collected quarterly from the following 13 locations at PORTS, identified in Fig. 6.14:

\section{6-26 Groundwater}



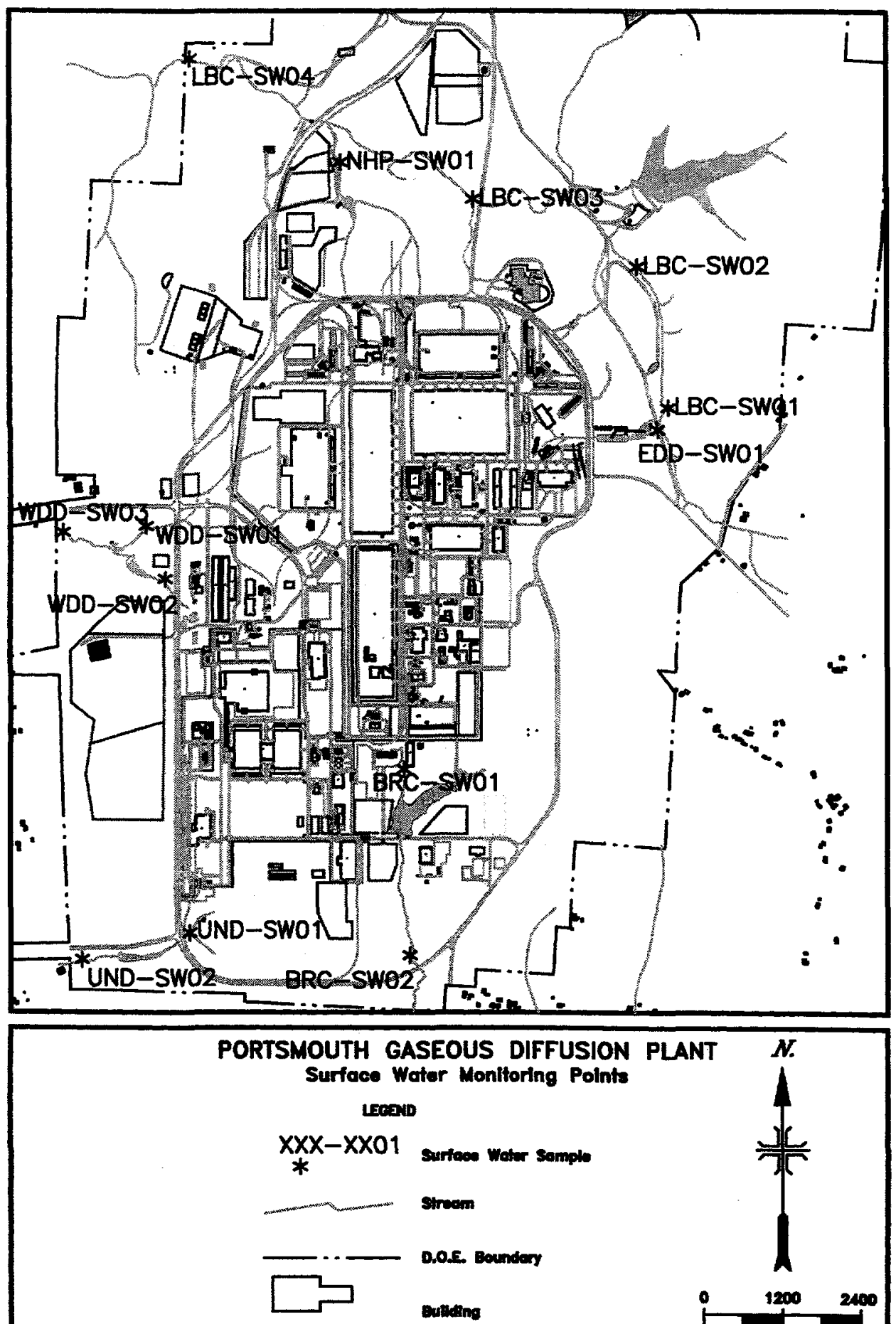

Fig. 6.14. Surface water monitoring locations. 
- Little Beaver Creek and East Drainage Ditch sample locations LBC-SW01, LBC-SW02, and EDD-SW01 assess possible $\mathrm{X}-701 \mathrm{~B}$ area plume groundwater discharges;

- Little Beaver Creek sample location LBC-SW03 serves in assessing potential contamination from the $X$ 611 A lime sludge lagoons;

- Big Run Creek sample locations BRC-SW01 and BRC-SW02 monitor groundwater discharges related to the X-231 B southwest oil biodegradation plot, the greater Quadrant I groundwater investigative area plume, and the X-749/X-120/Peter Kiewit landfill area plume, all of which discharge into the X-230K holding pond and Big Run Creek;

- The unnamed southwestern drainage ditch is sampled at two locations, UND-SW01 and UND-SW02, to assess potential contaminated groundwater releases to this creek and the $\mathrm{X}-2230 \mathrm{M}$ holding pond from the $\mathrm{X}-749 / \mathrm{X}-120 /$ Peter Kiewit landfill area plume;

- The North Holding Pond sample locations NHP-SW01 and LBC-SW04 assess additional contaminated groundwater discharges from any unknown Quadrant IV sources; and

- The West Drainage Ditch sample locations WDD-SW01, WDD-SW02, and WDD-SW03 appraise contaminated groundwater discharges from the X-616 area to the West Drainage Ditch and the X-2230N holding pond.

Surface water monitoring of the Big Run Creek, East Drainage Ditch, Little Beaver Creek, North Holding Pond, unnamed southwestern drainage ditch, and West Drainage Ditch is conducted quarterly to assess the effect of the discharge of groundwater to streams (as base flow) at PORTS. This monitoring helps to support assessment monitoring at X-231B and X-701B and post-closure monitoring at X-616, X-735, and $\mathrm{X}-749$. These surface monitoring locations are part of the Groundwater Monitoring Program and are not considered part of the PORTS NPDES sampling program.

No volatile organic compounds were detected at the surface water sampling locations in Big Run Creek, Little Beaver Creek, East Drainage Ditch, North Holding Pond, or West Drainage Ditch during 1998, with the exception of small amounts of chloroform and other trihalomethanes that are common residuals in treated chlorinated drinking water. These streams received such treated water. Trichloroethene has been detected regularly at UND-SW01 (inside the perimeter road) at low levels since 1990 and was detected in 1998 at 2-3 $\mu \mathrm{g} / \mathrm{L}$. Trichloroethene was also detected at UND-SW02 (downstream from UND-SW01) at 2 $\mu \mathrm{g} / \mathrm{L}$ in the second quarter of 1998.

Naturally occurring Sunbury shale chips and fines in the stream sediment contain trace concentrations of uranium, and these chips might account for the low uranium concentrations that were detected below preliminary remediation goals at many of the sampling locations in 1998. Gross alpha and beta activity were also detected at several sampling locations, but the activity was below preliminary remediation goals. 


\title{
7. Quality Assurance
}

\begin{abstract}
Quality assurance and quality control are essential components of environmental surveillance at DOE/PORTS. Quality is integrated into sample preservation, field data and sample collection, and sample transport. Numerous program assessment activities in the field and within the facilities are conducted at regular intervals to demonstrate that quality is built into and maintained in all DOE/PORTS programs.
\end{abstract}

\section{INTRODUCTION}

Quality assurance, an integral part of environmental surveillance, requires systematic control of the processes involved in sampling the environment and in analyzing the samples. To demonstrate accurate results, DOE/PORTS uses the following planned and systematic controls:

- implementation of standard operating procedures for sample collection and analysis;

- training and qualification of surveyors and analysts;

- implementation of sample tracking and chain-of-custody procedures to demonstrate traceability and integrity of samples and data;

- participation in external quality control programs;

- frequent calibration and routine maintenance of measuring and test equipment;

- maintenance of internal quality control programs;

- implementation of good measurement techniques and good laboratory practices; and

- frequent assessments of field sampling, measurement activities, and laboratory processes.

Environmental sampling is conducted at DOE/PORTS continually in accordance with state and federal regulations. Sampling plans and procedures are prepared, and appropriate sampling instruments or devices are selected in accordance with practices recommended by the U.S. EPA, the American Society for Testing and Materials, or other authorities. Chain-of-custody documentation is prepared from the point of sampling. The samples remain in the custody of the sampling group until they are transferred to the sample custodian at the chosen laboratory.

The analytical data are reviewed to determine compliance with applicable regulations and permits. The data are used to identify locations and concentrations of contaminants of concern, to evaluate the rate and extent of contamination at the site, and to help determine the need for remedial action. Adequate and complete documentation generated as a result of these efforts support the quality standards established at DOE/PORTS.

\section{FIELD SAMPLING AND MONITORING}

Personnel involved in field sampling and monitoring are properly trained. Procedures are developed from guidelines and regulations created by DOE or other regulatory agencies exercising authority over DOE/ PORTS activities. These procedures specify sampling protocol, sampling devices, and containers and preservatives to be used. Chain-of-custody procedures (used with all samples) are documented, and samples are controlled and protected from the point of collection to the generation of analytical results. 
Data generated from field sampling can be greatly influenced by the methods used to collect and transport the samples. A quality assurance program verifies that the samples are collected properly and represent the conditions that exist in the environment at the time of sampling. The DOE/PORTS quality assurance program mandates compliance with written sampling procedures, use of clean sampling devices and containers, use of approved sample preservation techniques, and collection of field blanks, trip blanks, and duplicate samples. Chain-of-custody procedures are strictly followed to verify that sample integrity is maintained. Samples are delivered to the laboratory as soon as practicable after collection to verify sample integrity.

\section{ANALYTICAL QUALITY ASSURANCE}

DOE/PORTS only uses analytical laboratories that demonstrate compliance in the following areas through participation in independent audits and surveillance programs:

- compliance with federal waste disposal regulations,

- data quality,

- materials management,

- sample control,

- data management,

- electronic data management,

- implementation of a laboratory quality assurance plan, and

- review of external and internal performance evaluation program.

DOE/PORTS participated in the U.S. EPA Discharge Monitoring Report Quality Assurance Study 18 in 1998. The study evaluated the analytical and reporting ability of the laboratories that routinely perform analyses required in NPDES permits. DOE/PORTS uses the USEC Portsmouth Analytical Laboratory for all NPDES sampling. The results of the study were satisfactory. 


\section{Appendix A: Radiation}

This appendix presents basic facts concerning radiation. The information is intended as a basis for understanding the dose associated with releases from DOE/PORTS, not as a comprehensive discussion of radiation and its effects on the environment and biological systems. The McGraw-Hill Dictionary of Scientific and Technical Terms defines radiation and radioactivity as follows.

radiation-1. The emission and propagation of waves transmitting energy through space or through some medium; for example, the emission and propagation of electromagnetic, sound, or elastic waves. 2. The energy transmitted through space or some medium; when unqualified, usually refers to electromagnetic radiation. Also known as radiant energy. 3. A stream of particles, such as electrons, neutrons, protons, alpha particles, or high-energy photons, or a mixture of these (McGraw-Hill 1989).

radioactivity-A particular type of radiation emitted by a radioactive substance, such as alpha radioactivity (McGraw-Hill 1989).

Radiation occurs naturally; it was not invented but discovered. People are constantly exposed to radiation. For example, radon in air, potassium in food and water, and uranium, thorium, and radium in the earth's crust are all sources of radiation. The following discussion describes important aspects of radiation, including atoms and isotopes; types, sources, and pathways of radiation; radiation measurement; and dose information.

\section{ATOMS AND ISOTOPES}

All matter is made up of atoms. An atom is "a unit of measure consisting of a single nucleus surrounded by a number of electrons equal to the number of protons in the nucleus" (American Nuclear Society 1986). The number of protons in the nucleus determines an element's atomic number, or chemical identity. With the exception of hydrogen, the nucleus of each type of atom also contains at least one neutron. Unlike protons, the number of neutrons may vary among atoms of the same element. The number of neutrons and protons determines the atomic weight. Atoms of the same element with a different number of neutrons are called isotopes. In other words, isotopes have the same chemical properties but different atomic weights. Figure A.1 depicts isotopes of the element hydrogen. Another example is the element uranium, which has 92 protons; all isotopes of uranium, therefore, have 92 protons. However, each uranium isotope has a different number of neutrons. Uranium-238 (also denoted ${ }^{238} \mathrm{U}$ ) has 92 protons and 146 neutrons; uranium-239 has 92 protons and 147 neutrons; uranium240 has 92 protons and 148 neutrons.

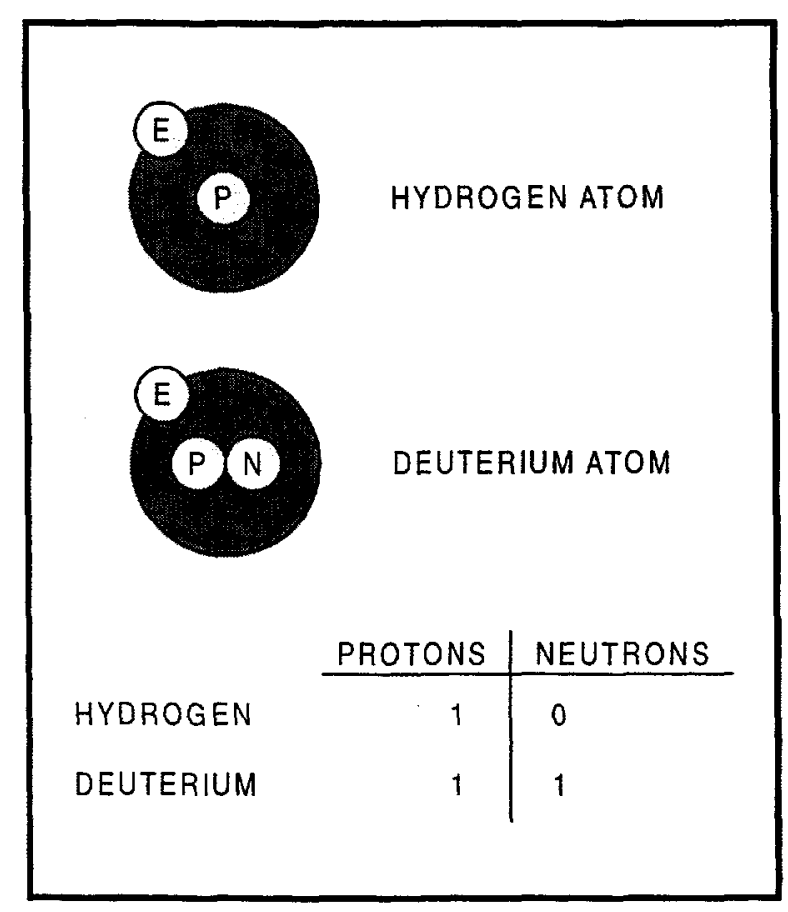

Fig. A.1. Isotopes of the element hydrogen. 
Some isotopes are stable, or nonradioactive; some are radioactive. Radioactive isotopes are called radioisotopes, or radionuclides. In an attempt to become stable, radionuclides "throw away," or emit, rays or particles. This emission of rays and particles is known as radioactive decay.

\section{RADIATION}

Radiation, or radiant energy, is energy in the form of waves or particles moving through space. Visible light, heat, radio waves, and alpha particles are examples of radiation. When people feel warmth from the sunlight, they are actually absorbing the radiant energy emitted by the sun.

Electromagnetic radiation is radiation in the form of electromagnetic waves; examples include gamma rays, ultraviolet light, and radio waves. Particulate radiation is radiation in the form of particles; examples include alpha and beta particles. Radiation also is characterized by the way in which it interacts with matter.

\section{Ionizing Radiation}

Normally, an atom has an equal number of protons and electrons; however, atoms can lose or gain electrons in a process known as ionization. Some form of radiation can ionize atoms by "knocking" electrons off atoms. Examples of ionizing radiation include alpha, beta, and gamma radiation. Ionizing radiation is capable of changing the chemical state of matter and subsequently causing biological damage and thus is potentially harmful to human health. Figure A.2 shows the penetrating potential of different types of ionizing radiation.

\section{Nonionizing Radiation}

Nonionizing radiation bounces off of or passes through

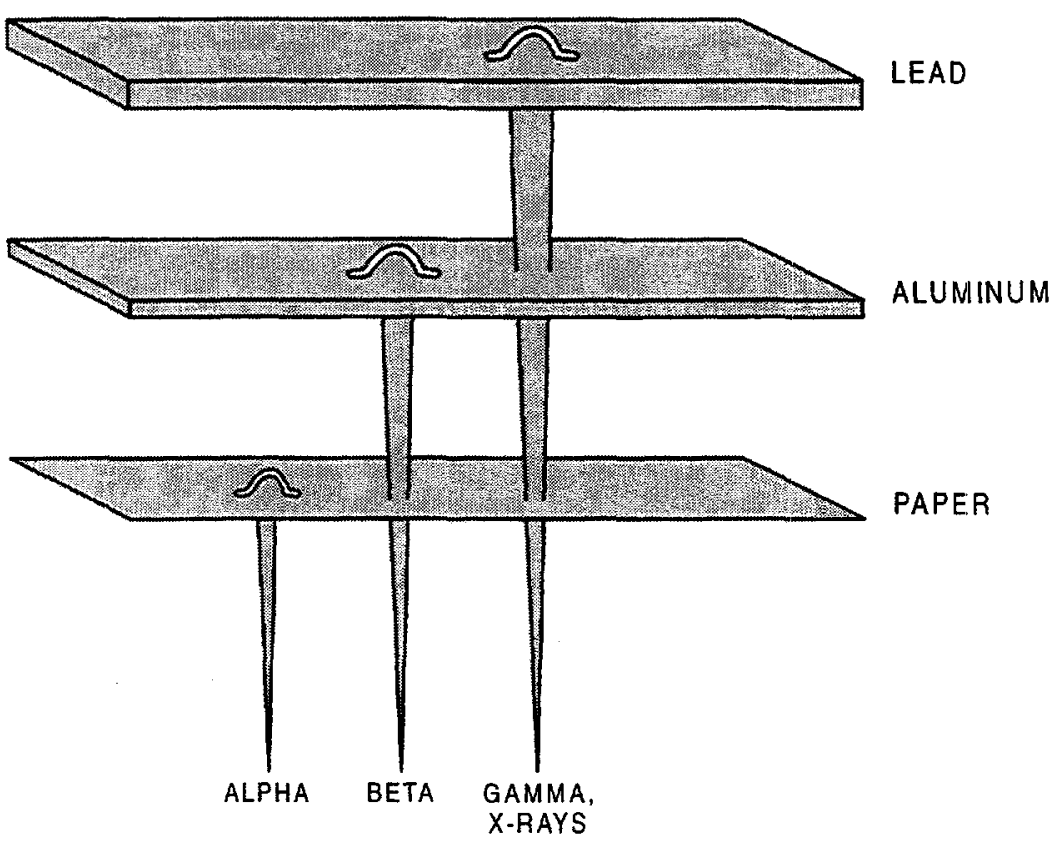

Fig. A.2. Penetrating power of radiation. matter without displacing electrons. Examples include visible light and radio waves. Currently, it is unclear whether nonionizing radiation is harmful to human health. In the discussion that follows, the term radiation is used to describe ionizing radiation. 


\section{SOURCES OF RADIATION}

Radiation is everywhere. Most occurs naturally, but a small percentage is human-made. Naturally occurring radiation is known as background radiation.

\section{Background Radiation}

Many materials are naturally radioactive. In fact, this naturally occurring radiation is the major source of radiation in the environment. Although people have little control over the amount of background radiation to which they are exposed, this exposure must be put into perspective. Background radiation remains relatively constant over time; background radiation present in the environment today is much the same as it was hundreds of years ago.

Sources of background radiation include uranium in the earth, radon in the air, and potassium in food. Background radiation is categorized as cosmic, terrestrial, or internal, depending on its origin.

\section{Cosmic Radiation}

Energetically charged particles from outer space continuously hit the earth's atmosphere. These particles and the secondary particles and photons they create are called cosmic radiation. Because the atmosphere provides some shielding against cosmic radiation, the intensity of this radiation increases with altitude above sea level. For example, a person in Denver, Colorado, is exposed to more cosmic radiation than a person in Death Valley, California.

\section{Terrestrial Radiation}

Terrestrial radiation refers to radiation emitted from radioactive materials in the earth's rocks, soils, and minerals. Radon $(\mathrm{Rn})$; radon progeny, the relatively short-lived decay products of radium- $235\left({ }^{235} \mathrm{Ra}\right)$; potassium $\left({ }^{40} \mathrm{~K}\right)$; isotopes of thorium $(\mathrm{Th})$; and isotopes of uranium $(\mathrm{U})$ are the elements responsible for most terrestrial radiation.

\section{Internal Radiation}

Radioactive material in the environment enters the body through the air people breathe and the food they eat; it also can enter through an open wound. Natural radionuclides in the body include isotopes of uranium, thorium, radium, radon, polonium, bismuth, and lead in the ${ }^{238} \mathrm{U}$ and ${ }^{232} \mathrm{Th}$ decay series. In addition, the body contains isotopes of potassium $\left({ }^{40} \mathrm{~K}\right)$, rubidium $\left({ }^{87} \mathrm{Rb}\right)$, and carbon $\left({ }^{14} \mathrm{C}\right)$.

\section{Human-Made Radiation}

Most people are exposed to human-made sources of radiation. Examples include consumer products, medical sources, and fallout from atmospheric atomic bomb tests. (Atmospheric testing of atomic weapons has been suspended in the United States and most parts of the world.) Also, about one-half of $1 \%$ of the U.S. population performs work in which radiation in some form is present. 


\section{Consumer Products}

Some consumer products are sources of radiation. In some of these products, such as smoke detectors and airport X-ray baggage inspection systems, radiation is essential to the performance of the device. In other products, such as television and tobacco products, the radiation occurs incidentally to the product function.

\section{Medical Sources}

Radiation is an important tool of diagnostic medicine and treatment, and, in this use, is the main source of exposure to human-made radiation. Exposure is deliberate and directly beneficial to the patients exposed. Generally, medical exposures from diagnostic or therapeutic X-rays result from beams directed to specific areas of the body. Thus, all body organs generally are not irradiated uniformly. Radiation and radioactive materials are also used in a wide variety of pharmaceuticals and in the preparation of medical instruments, including the sterilization of heat-sensitive products such as plastic heart valves. Nuclear medicine examinations and treatment involve the internal administration of radioactive compounds, or radiopharmaceuticals, by injection, inhalation, consumption, or insertion. Even then, radionuclides are not distributed uniformly throughout the body.

\section{Other Sources}

Other sources of radiation include fallout from atmospheric atomic bomb tests; emissions of radioactive materials from nuclear facilities such as uranium mines, fuel processing plants, and nuclear power plants; emissions from mineral extraction facilities; and the transportation of radioactive materials.

Transuranic materials are man-made radiological elements. They are created as a reaction in a reactor where uranium fuel is used. These elements are a group of isotopes that are all alpha emitting. They emit alpha particles similar to uranium alpha particles and are monitored by Health Physics at PORTS in the same manner as uranium. The transuranic isotopes that are detectable at PORTS are thorium-228, thorium-230, americium-241, neptunium-237, and plutonium-239/240.

\section{PATHWAYS OF RADIATION}

Radiation and radioactive materials in the environ-ment can reach people through many routes. Potential routes for radiation are referred to as pathways. For example, radioactive material in the air could fall on a pasture. The grass could then be eaten by cows, and the radioactive material on the grass would be present in the cow's milk. People drinking the milk would thus be exposed to this radiation. Or people could simply inhale the radioactive material in the air. The same events could occur with radioactive material in water. Fish living in the water would be exposed; people eating the fish would then be exposed to the radiation in the fish. Or people swimming in the water would be exposed (see Fig. A.3.).

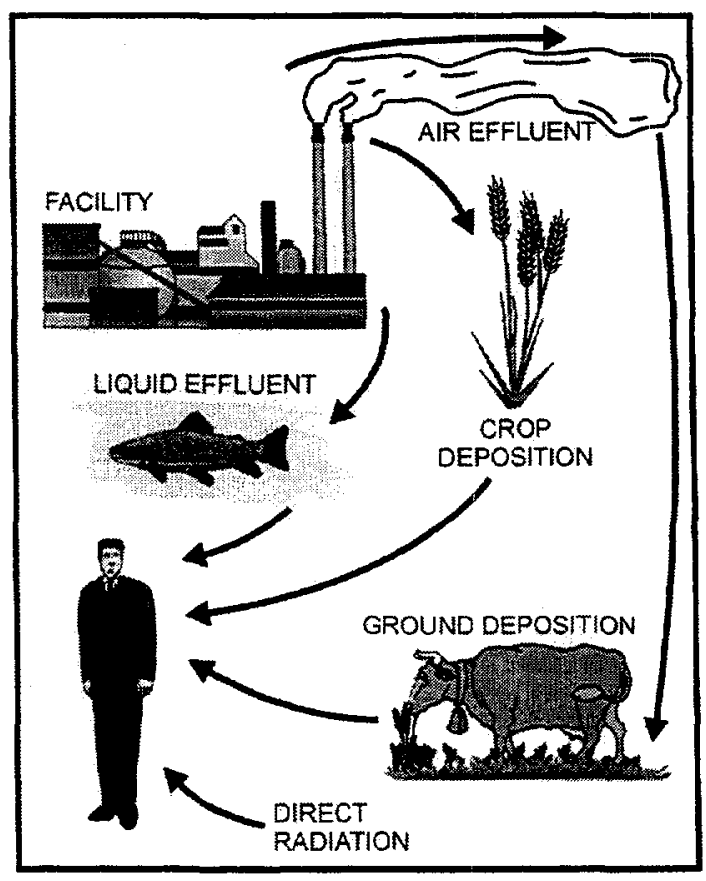

Fig. A.3. Possible radiation pathways.

\section{A-4 Appendix A: Radiation}




\section{MEASURING RADIATION}

To determine the possible effects of radiation on the environment and the health of people, the radiation must be measured. More precisely, its potential to cause damage must be determined.

\section{Activity}

When measuring the amount of radiation in the environment, what is actually being measured is the rate of radioactive decay, or activity. The rate of decay varies widely among the various radioisotopes. For that reason, 1 gram of a radioactive substance may contain the same amount of activity as several tons of another material. This activity is expressed in a unit of measure known as a curie (Ci). More specifically, $1 \mathrm{Ci}$ $=3.75 \mathrm{E}+10(37,000,000,000)$ atom disintegrations per second $(\mathrm{dps})$. In the international system of units, $1 \mathrm{dps}$ $=1$ becquerel $(\mathrm{Bq})$. Refer to Table A.1 for units of radiation measure and applicable conversions.

Table A.1. Units of radiation measures.

\begin{tabular}{ccc}
\hline Current System & Systeme International & Conversion \\
\hline curie (Ci) & Becquerel (Bq) & $1 \mathrm{Ci}=3.7 \times 10^{10} \mathrm{~Bq}$ \\
$\operatorname{rad}($ radiation absorbed dose) & Gray (Gy) & $1 \mathrm{rad}=0.01 \mathrm{~Gy}$ \\
$\operatorname{rem}($ roentgen equivalent man) & Sievert (Sv) & $1 \mathrm{rem}=0.01 \mathrm{~Sv}$ \\
\hline
\end{tabular}

\section{Absorbed Dose}

The total amount of energy absorbed per unit mass as a result of exposure to radiation is expressed in a unit of measure known as a rad. In the international system of units, $100 \mathrm{rad}$ equals 1 gray (Gy). In terms of human health, however, it is the effect of the absorbed energy that is important, not the actual amount.

\section{Dose Equivalent}

The measure of potential biological damage caused by exposure to and subsequent absorption of radiation is expressed in a unit of measure known as a rem. One rem of any type of radiation has the same total damaging effect. Because a rem represents a fairly large dose, dose is expressed as a millirem (mrem) or $1 / 1000$ of a rem. In the international system of units, 100 rem equals 1 sievert (Sv); 100 mrem equals 1 millisievert (mSv).

\section{DOSE}

Many terms are used to report dose. Several factors are taken into account, including the amount of radiation absorbed, the organ absorbing the radiation, and the effect of the radiation over a 50-year period. The term "dose," in this report, includes the committed effective dose equivalent and effective dose equivalent attributable to penetrating radiation from sources external to the body.

Determining dose is an involved process using complex mathematical equations based on several factors, including the type of radiation, the rate of exposure, weather conditions, and typical diet. Basically, radiant energy is generated from radioactive decay, or activity. People absorb some of the energy to which 
Table A.2. Comparison and description of various dose levels.

\begin{tabular}{|c|c|}
\hline Dose level & Description \\
\hline $1 \mathrm{mrem}(0.01 \mathrm{mSv})$ & Approximate daily dose from natural background radiation, including radon \\
\hline $2.5 \mathrm{mrem}(0.025 \mathrm{mSv})$ & $\begin{array}{l}\text { Cosmic dose to a person on a one-way airplane flight from New York to Los } \\
\text { Angeles }\end{array}$ \\
\hline $10 \mathrm{mrem}(0.10 \mathrm{mSv})$ & $\begin{array}{l}\text { Annual exposure limit, set up by the U.S. EPA, for exposures from airborne } \\
\text { emissions from operations of nuclear fuel cycle facilities, including power } \\
\text { plants and uranium mines and mills }\end{array}$ \\
\hline $46 \mathrm{mrem}(0.46 \mathrm{mSv})$ & $\begin{array}{l}\text { Estimate of the largest dose any off-site person could have received from the } \\
\text { March } 28,1979 \text {, Three Mile Island nuclear power plant accident }\end{array}$ \\
\hline $50 \mathrm{mrem}(0.50 \mathrm{mSv})$ & $\begin{array}{l}\text { Average yearly dose from cosmic radiation received by people in the } \\
\text { Portsmouth area }\end{array}$ \\
\hline $66 \mathrm{mrem}(0.66 \mathrm{mSv})$ & Average yearly dose to people in the United States from human-made sources \\
\hline $100 \mathrm{mrem}(1.00 \mathrm{mSv})$ & $\begin{array}{l}\text { Annual limit of dose from all DOE facilities to a member of the public who is } \\
\text { not a radiation worker }\end{array}$ \\
\hline $110 \mathrm{mrem}(1.10 \mathrm{mSv})$ & $\begin{array}{l}\text { Average occupational dose received by U.S. commercial radiation workers in } \\
1980\end{array}$ \\
\hline $244 \mathrm{mrem}(2.44 \mathrm{mSv})$ & Average dose from an upper gastrointestinal diagnostic $\mathrm{X}$-ray series \\
\hline $300 \mathrm{mrem}(3.00 \mathrm{mSv})$ & $\begin{array}{l}\text { Average yearly dose to people in the United States from all sources of natural } \\
\text { background radiation }\end{array}$ \\
\hline $1-5 \mathrm{rem}(0.01-0.05 \mathrm{~Sv})$ & $\begin{array}{l}\text { U.S. EPA protective action guideline calling for public officials to take } \\
\text { emergency action when the dose to a member of the public from a nuclear } \\
\text { accident will likely reach this range }\end{array}$ \\
\hline $5 \mathrm{rem}(0.05 \mathrm{~Sv})$ & $\begin{array}{l}\text { Annual limit for occupational exposure of radiation workers set by the Nuclear } \\
\text { Regulatory Commission and DOE }\end{array}$ \\
\hline $10 \mathrm{rem}(0.10 \mathrm{~Sv})$ & $\begin{array}{l}\text { The Biological Effects of Ionizing Radiations V report estimated that an acute } \\
\text { dose at this level would result in a lifetime excess risk of death from cancer } \\
\text { of } 0.8 \% \text { (Biological Effects of Ionizing Radiation 1990) }\end{array}$ \\
\hline $25 \mathrm{rem}(0.25 \mathrm{~Sv})$ & $\begin{array}{l}\text { U.S. EPA guideline for voluntary maximum dose to emergency workers for } \\
\text { non-lifesaving work during an emergency }\end{array}$ \\
\hline $75 \mathrm{rem}(0.75 \mathrm{~Sv})$ & $\begin{array}{l}\text { U.S. EPA guideline for maximum dose to emergency workers volunteering for } \\
\text { lifesaving work }\end{array}$ \\
\hline $50-600 \mathrm{rem}(0.50-6.00 \mathrm{~Sv})$ & $\begin{array}{l}\text { Doses in this range received over a short period of time will produce radiation } \\
\text { sickness in varying degrees. At the lower end of this range, people are } \\
\text { expected to recover completely, given proper medical attention. At the top } \\
\text { of this range, most people would die within } 60 \text { days }\end{array}$ \\
\hline
\end{tabular}

Adapted from Savannah River Site Environmental Report for 1993, Summary Pamphlet, WSRC-TR-94-076, Westinghouse Savannah River Company, 1994. 
they are exposed. This absorbed energy is calculated as part of an individual's dose. Whether radiation is natural or human-made, its effects on people are the same.

\section{Comparison of Dose Levels}

A scale of dose levels is presented in Table A.2. Included is an example of the type of exposure that may cause such a dose or the special significance of such a dose. This information is intended to familiarize the reader with the type of doses individuals may receive.

\section{Dose from Cosmic Radiation}

The average annual dose received by residents of the United States from cosmic radiation is about 27 mrem $(0.27 \mathrm{mSv})$ (National Council on Radiation Protection 1987). The average annual dose from cosmic radiation received by residents in the Portsmouth area is about $50 \mathrm{mrem}(0.50 \mathrm{mSv})$.

\section{Dose from Terrestrial Radiation}

The average annual dose received from terrestrial gamma radiation is about $28 \mathrm{mrem}(0.28 \mathrm{mSv})$ in the United States. This dose varies geographically across the country (National Council on Radiation Protection 1987); typical reported values are $16 \mathrm{mrem}(0.16 \mathrm{mSv})$ at the Atlantic and Gulf coastal plains and 63 mrem $(0.63 \mathrm{mSv})$ at the eastern slopes of the Rocky Mountains.

\section{Dose from Internal Radiation}

Short-lived decay products of radon are the major contributors to the annual dose equivalent for internal radionuclides (mostly ${ }^{222} \mathrm{Rn}$ ). They contribute an average dose of about $200 \mathrm{mrem}(2.00 \mathrm{mSv})$ per year. This dose estimate is based on an average radon concentration of about $1 \mathrm{pCi} / \mathrm{L}(0.037 \mathrm{~Bq} / \mathrm{L})(\mathrm{National}$ Council on Radiation Protection 1987).

The average dose from other internal radionuclides is about $39 \mathrm{mrem}(0.39 \mathrm{mSv})$ per year, most of which can be attributed to the naturally occurring isotope of potassium, ${ }^{40} \mathrm{~K}$. The concentration of radioactive potassium in human tissues is similar in all parts of the world (National Council on Radiation Protection 1987).

\section{Dose from Consumer Products}

The U.S. average annual dose received by an individual from consumer products is about 10 mrem (0.10 mSv) (National Council on Radiation Protection 1987).

\section{Dose from Medical Sources}

Nuclear medicine examinations, which involve the internal administration of radiopharmaceuticals, generally account for the largest portion of the dose received from human-made sources. The radionuclides used in specific tests, however, are not distributed uniformly throughout the body. In these cases, comparisons are made using the concept of effective dose equivalent, which relates exposure of organs or body parts to one effective whole-body dose. The average annual effective dose equivalent from medical examinations is 53 mrem $(0.53 \mathrm{mSv})$, including $39 \mathrm{mrem}(0.39 \mathrm{mSv})$ for diagnostic X-rays and $14 \mathrm{mrem}(0.14 \mathrm{mSv})$ for nuclear medicine procedures (National Council on Radiation Protection 1989). The actual doses received by individuals who complete such medical exams are much higher than these values, but not everyone receives such exams each year (National Council on Radiation Protection 1989). 


\section{Doses from Other Sources}

Small doses received by individuals occur as a result of radioactive fallout from atmospheric atornic bomb tests, emissions of radioactive materials from nuclear facilities, emissions from certain mineral extraction facilities, and transportation of radioactive materials. The combination of these sources contributes less than $1 \mathrm{mrem}(0.01 \mathrm{mSv})$ per year to the average dose to an individual (National Council on Radiation Protection 1987).

A comprehensive U.S. EPA report of 1984 projected the average occupational dose to monitored radiation workers in medicine, industry, the nuclear fuel cycle, government, and miscellaneous industries to be $105 \mathrm{mrem}(1.05 \mathrm{mSv})$ per year for 1985 , down slightly from $110 \mathrm{mrem}(1.10 \mathrm{mSv})$ per year in 1980 (Kumazawa et al. 1984). 


\section{Appendix B: Environmental Permits}

Table B.1. DOE/PORTS environmental permits and registrations.

\begin{tabular}{|c|c|c|c|c|}
\hline Permit/Registered Source & Source No. & Issue Date & Expiration Date & Status \\
\hline \multicolumn{5}{|c|}{ Clean Air Act Permits } \\
\hline Permit to Operate X-326 glovebox & P022 & $5 / 5 / 95$ & $4 / 27 / 01$ & $\begin{array}{c}\text { Active; Renewed } \\
4 / 27 / 98\end{array}$ \\
\hline $\begin{array}{l}\text { Registered Source X-345 emergency } \\
\text { generator }\end{array}$ & B005 & & None & Active \\
\hline Permit to Operate X-345 lab fume hood & P006 & & $11 / 3 / 98$ & $\begin{array}{c}\text { Expired } \\
\text { Source no longer in use }\end{array}$ \\
\hline $\begin{array}{l}\text { Permit to operate } \mathrm{X}-345 \text { high assay } \\
\text { sampling area }\end{array}$ & P008 & & $11 / 17 / 98$ & $\begin{array}{c}\text { Expired } \\
\text { Source no longer in use }\end{array}$ \\
\hline $\begin{array}{l}\text { Permit to Operate X-345 sampling glove } \\
\text { box vent }\end{array}$ & P009 & & $11 / 17 / 98$ & $\begin{array}{c}\text { Expired } \\
\text { Source no longer in use }\end{array}$ \\
\hline $\begin{array}{l}\text { Registered Source X-345 security fuel oil } \\
\text { tank }\end{array}$ & T005 & & None & Active \\
\hline $\begin{array}{l}\text { Registered Source X-623 groundwater } \\
\text { treatment facility }\end{array}$ & $\mathrm{P} 018$ & & None & Active \\
\hline $\begin{array}{l}\text { Permit to Operate } X-624 \text { groundwater } \\
\text { treatment facility }\end{array}$ & P019 & & $\begin{array}{l}\text { PTO renewal submitted } \\
\text { 11/4/98; PTO under appeal }\end{array}$ & Active \\
\hline $\begin{array}{l}\text { Permit to operate } \mathrm{X}-735 \text { landfill refuse and } \\
\text { asbestos handling }\end{array}$ & F001 & $2 / 8 / 93$ & $2 / 8 / 96$ & Canceled 5/12/98 \\
\hline $\begin{array}{l}\text { Permit to Operate } X-735 \text { landfill roads and } \\
\text { parking areas (southern portion) }\end{array}$ & F002 & $2 / 8 / 93$ & $2 / 8 / 96$ & Canceled $5 / 12 / 98$ \\
\hline $\begin{array}{l}\text { Permit to Operate } X-735 \text { landfill roads and } \\
\text { parking areas (northern portion) }\end{array}$ & F005 & $5 / 26 / 95$ & None & Canceled 5/12/98 \\
\hline $\begin{array}{l}\text { Registered Source X-735 landfill storage } \\
\text { piles }\end{array}$ & F006 & & None & $\begin{array}{l}\text { Source no longer } \\
\text { operating }\end{array}$ \\
\hline $\begin{array}{l}\text { Permit to Install Peter Kiewit landfill } \\
\text { roadways for cap construction }\end{array}$ & F008 & . & $11 / 21 / 98$ & $\begin{array}{c}\text { Inactive } \\
\text { Source no longer in use }\end{array}$ \\
\hline $\begin{array}{l}\text { Permit to Operate } X-735 \text { landfill cap and } \\
\text { venting system (northern portion) }\end{array}$ & P023 & $5 / 26 / 95$ & $4 / 27 / 01$ & $\begin{array}{c}\text { Renewed 4/27/98; } \\
\text { Active }\end{array}$ \\
\hline $\begin{array}{l}\text { Registered Source X-744G oil-fired } \\
\text { furnace }\end{array}$ & B006 & & None & Active \\
\hline Permit to Operate X-744G glovebox & $\mathrm{P} 007$ & & $\begin{array}{c}\text { PTO renewal submitted } \\
\text { 11/4/98; PTO under appeal }\end{array}$ & Active \\
\hline $\begin{array}{l}\text { Registered source } X-744 G \text { fuel oil tank } \\
\text { (south) }\end{array}$ & T008 & & None & $\begin{array}{c}\text { Active } \\
\text { Source no longer } \\
\text { operating }\end{array}$ \\
\hline Registered Source $X-744 G$ alumina melter & $\mathrm{P} 020$ & & None & $\begin{array}{l}\text { Active } \\
\text { Source no longer } \\
\text { operating }\end{array}$ \\
\hline $\begin{array}{l}\text { Registered Source X-749 contaminated } \\
\text { materials disposal facility }\end{array}$ & $\mathrm{P} 027$ & & None & Active \\
\hline
\end{tabular}




\begin{tabular}{|c|c|c|c|c|}
\hline Permit/Registered Source & Source No. & Issue Date & Expiration Date & Status \\
\hline Permit to Operate X-7725 drum dumper & P024 & & $11 / 17 / 98$ & $\begin{array}{c}\text { Expired } \\
\text { Source no longer in use }\end{array}$ \\
\hline $\begin{array}{l}\text { Registered Source X-7725 fluorescent bulb } \\
\text { crusher }\end{array}$ & P028 & & None & Active \\
\hline $\begin{array}{l}\text { Permit to Operate chrome sludge } \\
\text { repackaging }\end{array}$ & $\mathrm{P} 025$ & & $11 / 3 / 98$ & $\begin{array}{c}\text { Expired } \\
\text { Source no longer in use }\end{array}$ \\
\hline Permit to Operate mobile drum dumper & P026 & & $11 / 17 / 98$ & $\begin{array}{c}\text { Expired } \\
\text { Source no longer in use }\end{array}$ \\
\hline \multicolumn{5}{|c|}{ Clean Water Act Permits } \\
\hline NPDES Permit DOE & OI00000*GD & $8 / 5 / 95$ & $3 / 31 / 99 *$ & Active \\
\hline $\begin{array}{l}\text { Permit to Install X-622 groundwater } \\
\text { treatment facility }\end{array}$ & $06-2951$ & $11 / 20 / 90$ & None & Active \\
\hline $\begin{array}{l}\text { Permit to Install X-622T groundwater } \\
\text { treatment facility }\end{array}$ & $06-3520$ & $11 / 24 / 92$ & None & Active \\
\hline $\begin{array}{l}\text { Permit to Install X-623 groundwater } \\
\text { treatment facility }\end{array}$ & $06-3528$ & $1 / 9 / 96$ & None & Active \\
\hline $\begin{array}{l}\text { Permit to Install X-624 groundwater } \\
\text { treatment facility }\end{array}$ & $06-3556$ & $10 / 28 / 92$ & None & Active \\
\hline $\begin{array}{l}\text { U.S. Army Corps of Engineers-section } \\
404 \text {, nationwide permit No.6, radiological } \\
\text { survey }\end{array}$ & & $4 / 30 / 97$ & & \\
\hline
\end{tabular}

Hazardous Waste Permits

\begin{tabular}{|c|c|c|c|c|}
\hline RCRA Part B Permit & $\begin{array}{c}\text { RCRA- } \\
\text { LQG/TSDF } \\
\text { OH789000089 } \\
83 / 04-57-0680\end{array}$ & $8 / 25 / 95$ & $8 / 25 / 00$ & Active \\
\hline
\end{tabular}

\section{Registrations}

\begin{tabular}{lcccc}
\hline Underground Storage Tank Registration & 6651067 & $7 / 1 / 99$ & Active
\end{tabular}

* Permit will remain active until renewal application is acted upon by Ohio EPA. The NPDES Permit renewal application was submitted to the Ohio EPA on September 23, 1998. 


\section{Appendix C: Radionuclide and Chemical Nomenclature}

Table C.1. Nomenclature and half-life for radionuclides.

\begin{tabular}{lll}
\hline Radionuclide & ${ }^{\mathrm{Sym}}$ & Half-life \\
\hline Actinium-228 & ${ }^{228} \mathrm{Ac}$ & 6.2 hours \\
Americium-241 & ${ }^{241} \mathrm{Am}$ & 458 years \\
Beryllium-7 & ${ }^{7} \mathrm{Be}$ & 53.3 days \\
Bismuth-210 & ${ }^{210} \mathrm{Bi}$ & 5.01 days \\
Bismuth-214 & ${ }^{214} \mathrm{Bi}$ & 19.7 minutes \\
Lead-206 & ${ }^{206} \mathrm{~Pb}$ & Stable \\
Lead-210 & ${ }^{210} \mathrm{~Pb}$ & 22.3 years \\
Lead-212 & ${ }^{212} \mathrm{~Pb}$ & 10.6 hours \\
Lead-214 & ${ }^{214} \mathrm{~Pb}$ & 26.8 minutes \\
Neptunium-237 & ${ }^{237} \mathrm{~Np}$ & $2,140,000$ years \\
Plutonium-238 & ${ }^{238} \mathrm{Pu}$ & 86.4 years \\
Plutonium-239 & ${ }^{239} \mathrm{Pu}$ & 24,390 years \\
Plutonium-240 & ${ }^{240} \mathrm{Pu}$ & 6,580 years \\
Plutonium-241 & ${ }^{241} \mathrm{Pu}$ & 13.2 years \\
Plutonium-242 & ${ }^{242} \mathrm{Pu}$ & 379,000 years \\
Plutonium-244 & ${ }^{244} \mathrm{Pu}$ & $76,000,000$ years \\
Polonium-210 & ${ }^{210} \mathrm{Po}$ & 138.9 days \\
Polonium-214 & ${ }^{214} \mathrm{Po}$ & 164 microseconds \\
Polonium-218 & ${ }^{218} \mathrm{Po}$ & 3.05 minutes \\
Potassium-40 & ${ }^{40} \mathrm{~K}$ & $1,260,000,000$ years \\
Protactinium-233 & ${ }^{233} \mathrm{~Pa}$ & 27.0 days \\
Protactinium-234 & ${ }^{234} \mathrm{~Pa}$ & 6.7 hours \\
Protactinium-234m & ${ }^{234 m} \mathrm{~Pa}$ & 1.17 minutes \\
Radium-224 & ${ }^{224} \mathrm{Ra}$ & 3.7 days \\
Radium-226 & ${ }^{226} \mathrm{Ra}$ & 1,602 years \\
Radium-228 & ${ }^{228} \mathrm{Ra}$ & 5.8 years \\
Radon-222 & ${ }^{222} \mathrm{Rn}$ & 3.821 days \\
Technetium-99 & ${ }^{239} \mathrm{Tc}$ & 212,000 years \\
Thallium-208 & ${ }^{208} \mathrm{Tl}$ & 3.1 minutes \\
Thorium-228 & ${ }^{228} \mathrm{Th}$ & 1.9 years \\
Thorium-230 & ${ }^{230} \mathrm{Th}$ & 75,400 years \\
Thorium-231 & ${ }^{231} \mathrm{Th}$ & 25.5 hours \\
Thorium-232 & ${ }^{232} \mathrm{Th}$ & $14,000,000,000$ years \\
Thorium-234 & 24.1 days \\
Uranium-234 & 247,000 years \\
Uranium-236ium-238 & $710,000,000$ years \\
\hline
\end{tabular}


Table C.2. Nomenclature for elements and chemical constituents.

\begin{tabular}{|c|c|}
\hline Constituent & Symbol \\
\hline Aluminum & $\mathrm{Al}$ \\
\hline Ammonia & $\mathrm{NH}_{3}$ \\
\hline Antimony & $\mathrm{Sb}$ \\
\hline Arsenic & As \\
\hline Barium & $\mathrm{Ba}$ \\
\hline Beryllium & $\mathrm{Be}$ \\
\hline Cadmium & $\mathrm{Cd}$ \\
\hline Calcium & $\mathrm{Ca}$ \\
\hline Calcium carbonate & $\mathrm{CaCO}_{3}$ \\
\hline Carbon & $\mathrm{C}$ \\
\hline Chlorine & $\mathrm{Cl}$ \\
\hline Chromium & $\mathrm{Cr}$ \\
\hline Chromium, hexavalent & $\mathrm{Cr}_{6+}$ \\
\hline Cobalt & $\mathrm{Co}$ \\
\hline Copper & $\mathrm{Cu}$ \\
\hline Fluorine & $\mathrm{F}$ \\
\hline Hydrogen fluoride & $\mathrm{HF}$ \\
\hline Iron & $\mathrm{Fe}$ \\
\hline Lead & $\mathrm{Pb}$ \\
\hline Lithium & $\mathrm{Li}$ \\
\hline Magnesium & $\mathrm{Mg}$ \\
\hline Manganese & Mn \\
\hline Mercury & $\mathrm{Hg}$ \\
\hline Nickel & $\mathrm{Ni}$ \\
\hline Nitrogen & $N$ \\
\hline Nitrate & $\mathrm{NO}_{3}$ \\
\hline Nitrite & $\mathrm{NO}_{2}$ \\
\hline Oxygen & $\mathrm{O}$ \\
\hline Ozone & $\mathrm{O}_{3}$ \\
\hline Phosphorus & $\mathrm{P}$ \\
\hline Phosphate & $\mathrm{PO}_{4}$ \\
\hline Potassium & $\mathrm{K}$ \\
\hline Radium & $\mathrm{Ra}$ \\
\hline Radon & $\mathrm{Rn}$ \\
\hline Selenium & $\mathrm{Se}$ \\
\hline Silver & $\mathrm{Ag}$ \\
\hline Sodium & $\mathrm{Na}$ \\
\hline Sulfate & $\mathrm{SO}_{4}$ \\
\hline Sulfur dioxide & $\mathrm{SO}_{2}$ \\
\hline Thorium & Th \\
\hline Uranium & $\mathrm{U}$ \\
\hline Zinc & $\mathrm{Zn}$ \\
\hline
\end{tabular}




\section{References}

American Nuclear Society. 1986. Glossary of Terms in Nuclear Science and Technology, LaGrange Park, Ill. Beres, D.A., 1990. The Clean Air Act Assessment Package - 1988 (CAP-88): A Dose and Risk Assessment Methodology for Radionuclide Emissions to Air, SC\&A, Inc., McLean, Va.

Biological Effects of Ionizing Radiations. 1990. Health Effects of Exposure to Low Levels of Ionizing Radiotion, Committee on the Biological Effects of Ionizing Radiations (BEIR V), National Research Council, National Academy of Sciences, National Academy Press, Washington, D.C.

International Commission on Radiological Protection (ICRP). 1977. Annuals of the ICRP 1, ICRP Publication 26, Pergamon, Oxford, N.Y.

International Commission on Radiological Protection. 1978. Publication 30, Pergamon, Oxford, N.Y.

Kumazawa, S., et al. 1984. Occupational Exposures to Ionizing Radiation in the United States: A Comprehensive Review for the Year 1980 and a Summary of Trends for the Years 1960-1985, EPA/520/18-005, U.S. Government Printing Office, Washington, D.C.

McGraw-Hill. 1989. McGraw-Hill Dictionary of Scientific and Technical Terms, $4^{\text {th }}$ ed., McGraw-Hill, Inc., New York.

National Council on Radiation Protection (NCRP). 1987. Ionizing Radiation Exposure of the Population of the United States., NCRP Report No. 93, National Council on Radiation Protection and Measurements, Washington, D.C.

National Council on Radiation Protection. 1989. Exposure of the U.S. Population from Diagnostic Medical Radiation, NCRP Report No. 100, National Council on Radiation Protection and Measurements, Bethesda, Md.

U.S. Environmental Protection Agency. 1989. Risk Assessment Guidance for Superfund: Human Health Evaluation Manual, Part A (Interim Final), Washington, D.C. 


\section{Glossary}

absorption - The process by which the number and energy of particles or photons entering a body of matter are reduced by interaction with the matter.

activity - See "radioactivity."

alpha particle - A positively charged particle having the same charge and mass as that of a helium nucleus (two protons and two neutrons). Alpha particles are emitted from the nucleus of an atom during radioactive decay.

ambient air - The atmosphere around people, plants, and structures.

analyte - A constituent or parameter being analyzed.

aquifer - A geologic formation capable of yielding a significant amount of groundwater to wells or springs.

atom - Smallest particle of an element capable of entering into a chemical reaction.

background radiation - Radiation that occurs naturally in the surrounding environment.

baffling - A device, such as a wall or screen, used to deflect, check, or regulate the flow of liquid.

Becquerel (Bq) - The International Standard unit that measures the amount of radiation in disintegrations per second. Radioactivity is caused when atoms disintegrate, ejecting energetic particles. One Becquerel is the radiation caused by one disintegration per second.

beta particle - A negatively charged particle emitted from the nucleus of an atom during radioactive decay. It has a mass and charge equal to those of an electron.

biota - The animal and plant life of a particular region considered as a total ecological entity.

bladder pump - A specialized pump that uses the low-flow sampling technique to collect water samples.

categorical exclusion - A class of actions that either individually or cumulatively would not have a significant effect on the human environment and therefore would not require preparation of an environmental assessment or environmental impact statement under the National Environmental Policy Act.

chain-of-custody - A form that documents sample collection, transport, and analysis.

closure - Control of a closed hazardous waste management facility under Resource Conservation and Recovery Act requirements.

compliance - Fulfillment of applicable regulations or requirements of a plan or schedule ordered or approved by a government authority. 
concentration - The amount of a substance contained in a unit volume or mass of a sample.

cone of depression - The depression, roughly conical in shape, produced in a water table or piezometric surface by pumping.

contamination - Deposition of unwanted material on the surfaces of structures, areas, objects, or personnel.

cosmic radiation - Ionizing radiation with very high energies that originates outside the earth's atmosphere. Cosmic radiation is one contributor to natural background radiation.

critical habitat - Specific areas that may require special management considerations or protection and on which physical or biological features essential to the conservation of a species are found.

critical pathway - The route through which individuals can be exposed to airborne and liquid releases of radioactive and chemical materials.

curie (Ci) - A unit of radioactivity. One curie is defined as $3.7 \times 10^{10}$ (37 billion) disintegrations per second. Several fractions and multiples of the curie are commonly used:

kilocurie (kCi) $-10^{3} \mathrm{Ci}$, one thousand curies; $3.7 \times 10^{13}$ disintegrations per second. millicurie ( $\mathrm{mCi})-10^{-3} \mathrm{Ci}$, one-thousandth of a curie; $3.7 \times 10^{7}$ disintegrations per second. microcurie $(\mu \mathrm{Ci})-10^{-6} \mathrm{Ci}$, one-millionth of a curie, $3.7 \times 10^{4}$ disintegrations per second. picocurie (pCi) $-10^{-12} \mathrm{Ci}$, one-trillionth of a curie; 0.037 disintegration per second.

daughter - A nuclide formed by the radioactivity decay of a parent nuclide.

decay, radioactive - The spontaneous transformation of one radionuclide into a different radioactive or: nonradioactive nuclide or into a different energy state of the same radionuclide.

decontamination and decommissioning - The cleanup and removal of buildings, structures, or objects contaminated with hazardous substances during past production or disposal activities.

dense nonaqueous phase liquid - A liquid such as a chlorinated organic solvent (e.g., tetrachloroethene and trichloroethene) that is heavier than water and not completely soluble in water. A dense nonaqueous phase liquid sinks to the bottom of an aquifer and is difficult to remediate.

derived concentration guide - The concentration of a radionuclide in air or water that under conditions of continuous exposure for one year by one exposure mode (i.e., ingestion of water, submersion in air, or inhalation) would result in either an effective dose equivalent of $0.1 \mathrm{rem}(1 \mathrm{mSv})$ or a dose equivalent of $5 \mathrm{rem}(50$ $\mathrm{mSv}$ ) to any tissue, including skin and the lens of the eye. The guidelines for radionuclides in air and water are provided in DOE Order 5400.5, Radiation Protection of the Public and the Environment.

disintegration, nuclear - A spontaneous nuclear transformation (radioactivity) characterized by the emission of energy and/or mass from the nucleus of an atom.

dissolved solids - Organic or inorganic material dissolved in water. Excessive amounts of dissolved solids make water unfit to drink or to use in industrial processes.

downgradient - In the direction of decreasing hydrostatic head.

\section{G-2 Glossary}


downgradient well - A well installed hydraulically downgradient of a site that may be capable of detecting migration of contaminants from a site.

effluent - A liquid or gaseous waste discharge to the environment.

effluent monitoring - The collection and analysis of samples or measurement of liquid and gaseous effluents to characterize and quantify the release of contaminants, assess radiation exposures to the public, and demonstrate compliance with applicable standards.

Environmental Restoration - A DOE program that directs the assessment and cleanup of its sites (remediation) and facilities (decontamination and decommissioning) contaminated with waste as a result of nuclearrelated activities.

exposure (radiation) - The incident of radiation on living or inanimate material by accident or intent. Background exposure is the exposure to natural background ionizing radiation. Occupational exposure is exposure to ionizing radiation that takes place at a person's workplace. Population exposure is the exposure to the total number of persons who inhabit an area.

external radiation - The exposure to ionizing radiation when the radiation source is located outside the body.

formation - In geologic terms, a unit of rock or a unit of material that could form a rock such as sand.

friable - The ability of a material to be pulverized, crumbled, or reduced to powder by hand pressure when dry.

gamma ray - High-energy short-wavelength electromagnetic radiation emitted from the nucleus of a charged atom. Gamma rays are identical to X-rays except for the source of the emission.

Gaussian puff/plume model - A computer-simulated atmospheric dispersion of a release using a Gaussian (normal) statistical distribution to determine concentrations in air.

geochemical - Broadly defined as relating to all parts of geology that involve chemical changes, or narrowly defined as the distribution of the elements.

glovebox - An enclosure with built-in sleeves and gloves used by a person to manipulate hazardous materials such as highly enriched uranium without directly exposing the person to the material.

grab sample - A sample collected instantaneously with a glass or plastic bottle placed below the water surface to collect surface water samples (also called dip samples).

gray (Gy) - The International Standard unit of measurement of absorbed radiation.

groundwater - Water below the land surface in a zone where all void space between rocks, soil, etc., is filled with water.

hexavalent - A compound that has six valence electrons.

half-life, radiological - The time required for half of a given number of atoms of a specific radionuclide to decay. Each nuclide has a unique half-life.

hydraulic conductivity - The rate at which water can move through a permeable medium. 
hydraulic fracturing - The fracturing of soil or rock accomplished by pumping a fluid into a well in order to produce artificial openings in the media, thereby increasing permeability.

hydraulic gradient - The direction of groundwater flow due to changes in the depth of the water table.

hydrocarbon - A chemical compound that consists entirely of carbon and hydrogen.

hydrology - The science dealing with the properties, distribution, and circulation of natural water systems.

hydrogeology - Aspect of geology that deals with the movement of water below ground surface.

hydrophytic - The ability of a plant to grow in and adapt to a very wet environment.

industrial solid waste landfill - A type of landfill that exclusively disposes of solid waste generated by manufacturing or industrial operations.

in situ - In its original place; field measurements taken without removing the sample from its origin; remediation performed while the contaminated media (e.g., groundwater) remains below the surface.

interim remedial measure - Cleanup activities initiated after it has been determined that contamination or waste disposal practices pose an immediate threat to human health and/or the environment. These measures are implemented until a more permanent solution can be made.

internal radiation - Occurs when natural radionuclides enter the body by ingestion of food or water or by inhalation. Radon is the major contributor to the annual dose equivalent for internal radionuclides.

ion - An atom or compound that carries an electrical charge.

irradiation - Exposure to radiation.

isotopes - Forms of an element having the same number of protons but differing numbers of neutrons in their nuclei.

long-lived isotope - A radionuclide that decays at such a slow rate that a given quantity will exist for an extended period (half-life is greater than three years).

short-lived isotope - A radionuclide that decays so rapidly that a given quantity is transformed almost completely into decay products within a short period (half-life is two days or less).

jurisdictional wetland - An area that is periodically or permanently inundated by surface or ground water, supports hydrophytic vegetation, and has hydric soils, but is not associated with an active holding pond.

leachate - A liquid that results from water collecting contaminants as it trickles through wastes, agricultural pesticides, or fertilizers. Leaching may occur in farming areas, feed lots, and landfills and may result in hazardous substances entering surface water, groundwater, or soil.

manifest - A form required by RCRA that is used to document and track waste during transportation and disposal.

mass-balance calculation - A calculation used to demonstrate that the amount of pollutants entering a system is equal to the amount that exits the system.

\section{G-4 Glossary}


maximally exposed individual - A hypothetical individual who remains in an uncontrolled area and would, when all potential routes of exposure from a facility's operations are considered, receive the greatest possible dose equivalent.

maximum contaminant level - The maximum permissible level of a contaminant in drinking water provided by a public water system.

migration - The transfer or movement of a material through air, soil, or groundwater.

monitoring - Process whereby the quantity and quality of factors that can affect the environment or human health are measured periodically to regulate and control potential impacts.

mrem - The dose equivalent that is one-thousandth of a rem.

natural radiation - Radiation from cosmic and other naturally occurring radionuclide sources (such as radon) in the environment.

non-jurisdictional wetland - An area that is periodically or permanently inundated by surface or ground water, supports hydrophytic vegetation, has hydric soils, and is associated with an active holding pond.

nuclide - An atom specified by atomic weight, atomic number, and energy state. A radionuclide is a radioactive nuclide.

outfall - The point of conveyance (e.g., drain or pipe) of wastewater or other effluents into a ditch, pond, or river.

palladized - Coated with palladium.

parent nuclide - An element from which other elements are formed through the loss of protons.

person-rem - Collective dose to a population group. For example, a dose of 1 rem to 10 individuals results in a collective dose of 10 person-rem.

pH - A measure of the hydrogen ion concentration in an aqueous solution. Acidic solutions have a pH from 0 to 7 , neutral solutions have a $\mathrm{pH}$ equal to 7 , and basic solutions have a pH from 7 to 14 .

polychlorinated biphenyl - An industrial compound, used primarily as a lubricant, which is produced by adding chlorine to biphenyl, a colorless, crystalline compound.

preliminary remediation goal - The concentration of a constituent in environmental media (soil, groundwater, etc.) that is considered protective of human health and the environment.

quality assurance - Any action in environmental monitoring to demonstrate the reliability of monitoring and measurement data.

quality control - The routine application of procedures within environmental monitoring to obtain the required standards of performance in monitoring and measurement processes.

quiescent - Marked by a state of inactivity; being at rest; latent, or dormant. 
rad - The unit of absorbed dose deposited in a volume of material.

radioactivity - The spontaneous emission of radiation, generally alpha or beta particles or gamma rays, from the nucleus of an unstable isotope.

radioisotopes - Radioactive isotopes.

radionuclide - An unstable nuclide capable of spontaneous transformation into other nuclides by changing its nuclear configuration or energy level. This transformation is accomplished by the emission of photons or particles.

release - Any discharge to the environment. "Environment" is broadly defined as any water, land, or ambient air.

rem - The unit of dose equivalent (absorbed dose in rads multiplied by the radiation quality factor). Dose equivalent is frequently reported in units of millirem (mrem), which is one-thousandth of a rem.

remediation - The correction or cleanup of a site contaminated with waste. See "Environmental Restoration."

reportable quantity - A release to the environment that exceeds reportable quantities as defined by the Comprehensive Environmental Response, Compensation, and Liability Act.

Resource Conservation and Recovery Act (RCRA) - Legislation that regulates the transport, treatment, and disposal of solid and hazardous wastes.

roentgen - A unit of exposure from X-rays or gamma rays. One roentgen equals $2.58 \times 10^{-4}$ coulombs per $\mathrm{kg}$ of air.

routine radioactive release - A planned or scheduled release of radioactivity to the environment.

sievert (Sv) - The International System of Units unit of dose equivalent; $1 \mathrm{~Sv}=100 \mathrm{rem}$.

slaked - Crumbled (lime) due to mixture with water.

slurry - A suspension of solid particles (sludge) in water.

source - A point or object from which radiation or contamination emanates.

stable - Not radioactive or not easily decomposed or otherwise modified chemically.

standard deviation - An indication of the dispersion of a set of results around their average.

Superfund - The program operated under the legislative authority of the Comprehensive Environmental Response, Compensation, and Liability Act and Superfund Amendments and Reauthorization Act that funds and conducts EPA emergency and long-term removal and remedial actions.

surface water - All water on the surface of the earth, as distinguished from groundwater.

suspended solids - Mixture of fine, nonsettling particles of any solid within a liquid or gas. 
terrestrial radiation - Ionizing radiation emitted from radioactive materials in the earth's soils such as potassium-40, thorium, and uranium. Terrestrial radiation contributes to natural background radiation.

transuranics - Elements such as plutonium and neptunium that have atomic numbers (the number of protons in the nucleus) greater than 92. All transuranics are radioactive.

trip blank - A quality control sample of water that accompanies sample containers from the analytical laboratory, to the field sampling location where environmental samples are collected, back to the analytical laboratory to determine whether environmental samples have been contaminated during shipment.

trivalent - A compound that has three valence electrons.

troughing system - A system designed to collect leaking polychlorinated biphenyls in the process buildings.

turbidity - A measure of the concentration of sediment or suspended particles in solution.

upgradient - In the direction of increasing hydrostatic head.

upgradient well - A well installed hydraulically upgradient of a site to provide data to compare to a downgradient well to determine whether the site is affecting groundwater quality.

vadose zone - Soil zone located above the water table.

volatile organic compounds - Chemicals composed primarily of hydrogen, oxygen, and carbon that readily volatilize into the air. They include light alcohols, acetone, trichloroethene, dichloroethene, benzene, vinyl chloride, toluene, methylene chloride, and many other compounds.

watershed - The region draining into a river, river system, or body of water.

wetland - A lowland area, such as a marsh or swamp, inundated or saturated by surface or groundwater sufficiently to support hydrophytic vegetation typically adapted to life in saturated soils.

\section{Acronyms}

$\mathrm{Bq} \quad$ Becquerel

$\mathrm{Ci} \quad$ curie

DOE U.S. Department of Energy

EPA Environmental Protection Agency

kg kilogram

$\mu \mathrm{g} / \mathrm{L} \quad$ microgram per liter (equivalent to part per billion) 
NPDES National Pollutant Discharge Elimination System

$\mathrm{pCi} / \mathrm{L} \quad$ picocurie per liter

PORTS Portsmouth Gaseous Diffusion Plant

RCRA Resource Conservation and Recovery Act

TLD thermoluminescent dosimeter

USEC United States Enrichment Corporation 